\title{
فاعلية برنامج تدريبى باستخدام استراتيجيات التعلم النشط في تنمية بعض مهارات التنمية البشرية لدى معلمة الروضة
}

\author{
إعراد \\ د/ مضاوي عبد الرحمن الراشل \\ أستاذ مساعد بكليتّا التربيتً \\ جامعتّالأميرة نوره بنت عبدالرحمن \\ قسم الطفولث
}

المجلت العلميتّ لكليتترياض الأطفال ـ جامعت المنصورة

المجلد الخامس ـ العدد الرابع

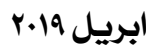


فاعلية برنامج تدريبى باستخدام استراتيجيات التعلم النشط فى تنمية بعض مهارات التنمية البشرية للدى معلمة الروضة

د مضاوي عبد الرحمن الراشد *

\section{ملخص البحث}

هدف البحث إلى التعـرف علــى فاعليــة برنــامج تــدريبى باســتخدام

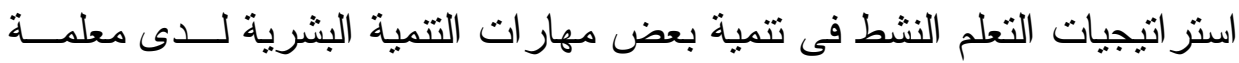
الروضة، واستخدام المنهج الثبه تجريبى ذو المجموعة الواحدة، وتكونت عينة

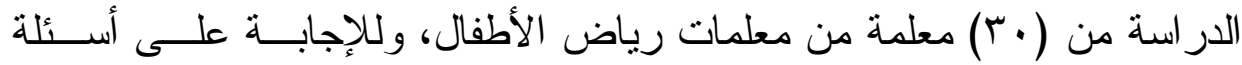

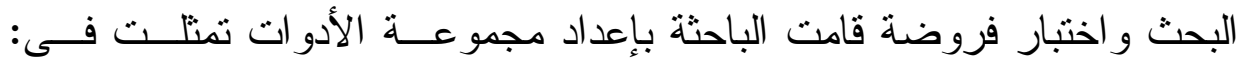

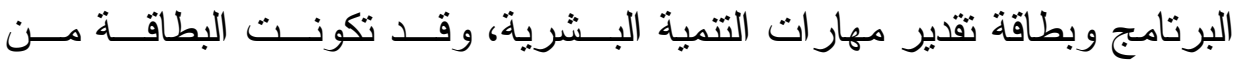

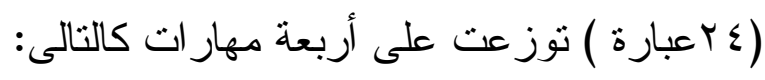
أ- مهارة الاتصال اللفظى و غير لفظى تتكون من (؟) عبار ات . ب- مهارة إدارة الصف تتكون من (T) عبار ات. ج- مهارة التعزيز تتكون من (ך) عبار ات د- مهارة القياس و التقويم تتكون من (ך) عبار ات

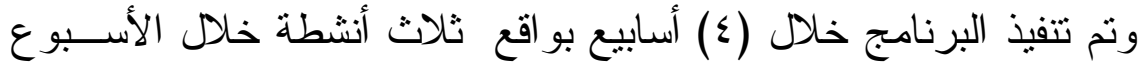

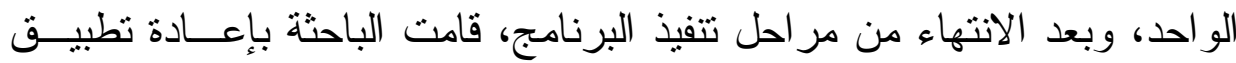

* أستاذ مساعد بكليت التربيتة ـ جامعت الأميرة نوره بنت عبدالرحمن ـ قسم الطفولت 
بطاقة تقدير مهار ات التتمية البشرية، كتطبيق بعدى لمعرفة دلالة فاعلية البرنامج

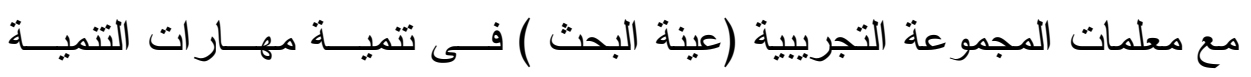

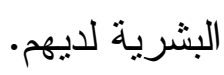

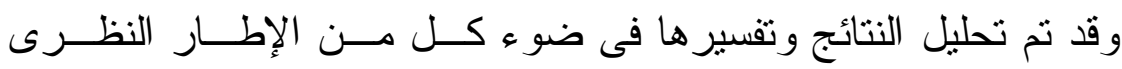

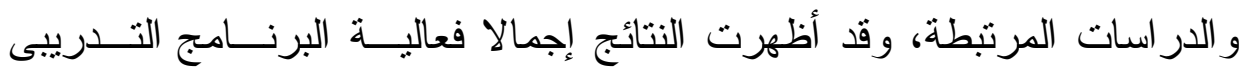

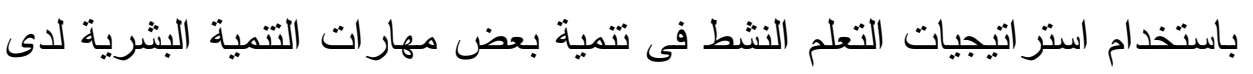

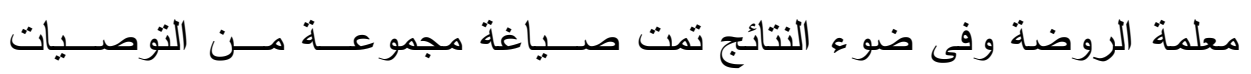
و البحوث المقترحة. 


\begin{abstract}
The aim of the research was to identify the effectiveness of a training program using active learning strategies in developing some of the human development skills of the kindergarten teacher and the use of the experimental onegroup approach. The sample consisted of (30) kindergarten teachers, the researcher prepared the toolkit represented in: the program and the card skills assessment of human development, the card was composed of ( 24 words) distributed on four skills as follows:
\end{abstract}

A. verbal and nonverbal communication skill consists of (6) phrases.

B. The skill of managing the class consists of (6) phrases.

C. A booster skill consists of (6) phrases.

D. The skill of measurement and evaluation consists of (6) phrases.

The program was implemented during four weeks with three activities per week. After completing the program implementation stages, the researcher re-applied the human development skills assessment card as a remote application to find out the effectiveness of the program with the experimental group parameters in development skills development They have humanity.

The results were analyzed and interpreted in light of both the theoretical framework and the related studies. Overall, the results showed the effectiveness of the training program using active learning strategies in the development of some human development skills in kindergarten teacher.

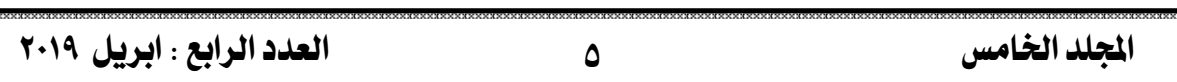




\section{فاعلية برنامج تدريبى باستخدام استراتيجيات

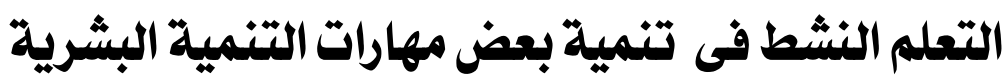

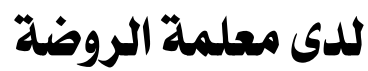

\section{د د مضاوي عبد الرحمن الراشد *}

أصبحت العناية بالجودة الثاملة هدفًا عالميًا فى مختلف مجــالات الحيــاة الانسانية، ويتطلب ذللك ضرورة الإعداد التزبوى لمعلمة الروضة علىى وجــه التحديد بكليات التزبية من خلال تقديم بر امج عصرية تسهم بفاعلية فى تحسسين استر اتيجيات التعلم و التعليم سو اء فى غرفة الصف أو خارجها وتكسب المعلىــــة

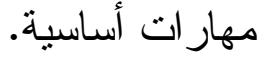

قد كان التركيز على أهية الاستر اتيجيات التى تجعـل المـتـعلم محسـورًا للعملية التعليمية، بحيث يتحول دور المعلم من تلقين المعلومات إلى تيسير عملية التعلم، ويتحول دور المتعلم من تلقى المعلومات واستظهارها إلى دور نشط يينى

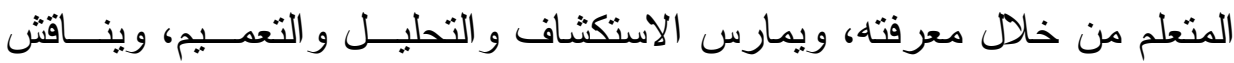

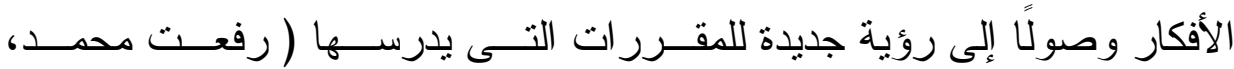

نخص هنا استر اتيجيات التعلم النشط، وهى اســتر اتيجيات تـشمل مــدى واسع من الأنشطة التى تشارك فى العناصر الأساسية، والتى تحث الطلاب على الثى

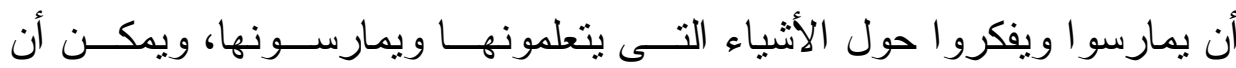

* أستاذ مساعد بكليتالتربيتً ـ جامعت الأميرة نوره بنت عبدالرحمن ـقسم الطفولة 
تستخدم هذه الاستر اتيجيات فى حث الطلاب على أن بنشغلو ا فى التفكير الناقــد و الابداعى، و التحدث مع أقر انهم أو المجاميع الصغيرة أو الصف، كذلك تجعلهم

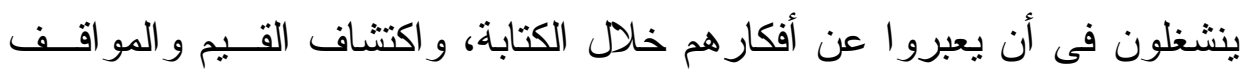
الثخصية، وتقديم و استقبال التغذية الر اجعة، و التأمل خلال عمليات التعلم. تعد المعلمة أهم مدخلات العملية التعليمية وذلك لكونها العنصر الأهم فى "ماتى

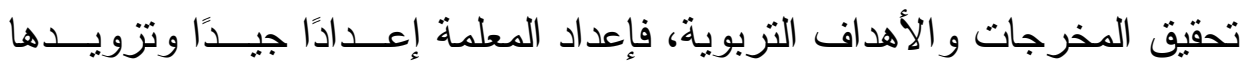

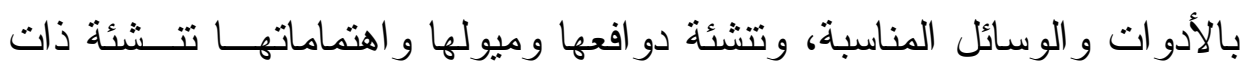

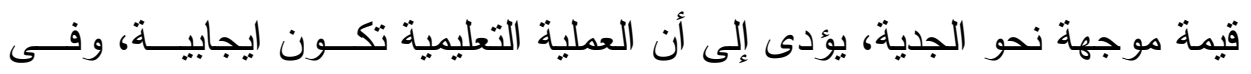

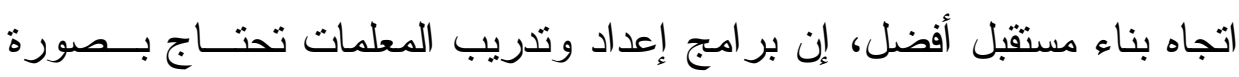

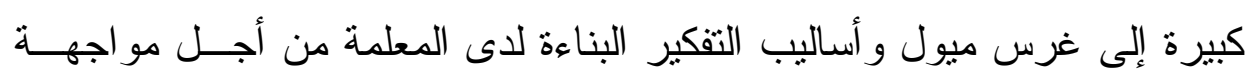

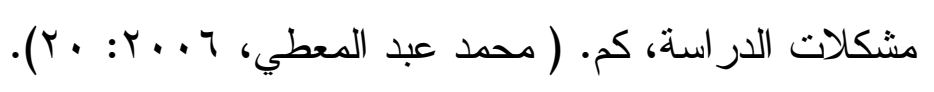
يمنل تدريب المعلمين حاليًا ضرورة ملحة خاصة فى أقطارنـــا العربيـــة، حيث أوصت عديد من المؤتمر ات بالاهتمام بإعداد وتدريب المعلمين ومن ضمن

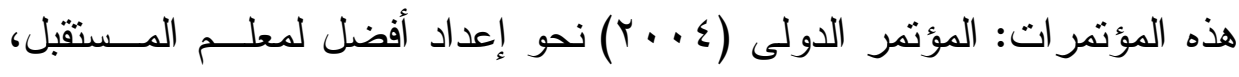
مسقط، كلية تربية، جامعة السلطان قابوس، وقد أجمعت جميع المؤتمر ات مسن خلال توصياتها على ضرورة تطوير وتحديث بر امج وأساليب و إعداد وتـدريب

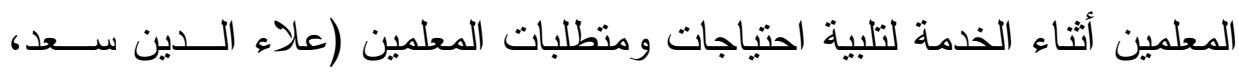
. (rqr-rqr: $r \cdot \ldots$

استر اتيجية التعلم النشط يمكن أن تساهم فى تتمية المهــار ات التثريسـية، و التى تعتمد على مشاركة الطلاب بصورة أكثر فاعلية فى الموقــف التعليمـى،

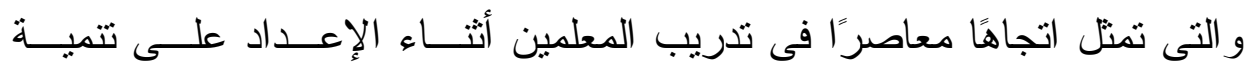

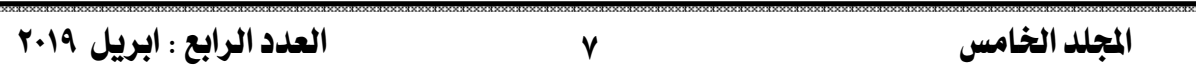


مهار اتهم التتريسية، وقد ظهرت استر اتيجيات التعلم النـشط انعكاستـــا لأفكـــار النظرية المعرفية التى ترى أن التعلم يتضمن التعلم النشط من جانب المتعلم فـى تكوين أو بناء مخططات يوظفها فى فهم المادة العلمية، فالمتعلم ينشئ المعرفـــة

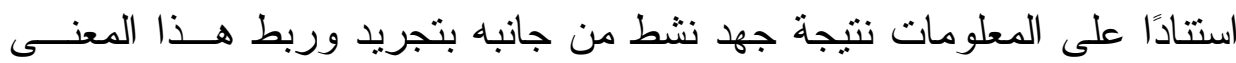

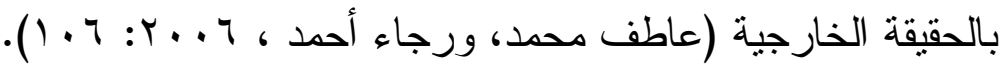

فالتتمية البشرية تحتل مكانتها فى الفكر التربــوى فهـى تتـصرف فـى جوهرها إلى زيادة الطاقة الانتاجية للمعلم، فالتتمية البشرية فى عصر تكنولوجيا

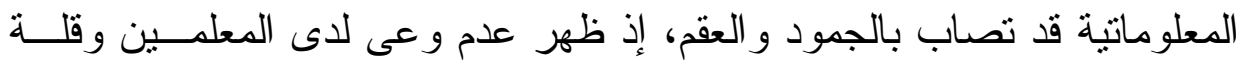

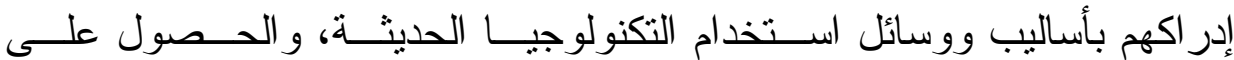
المعلومات، إلى جانب أن كثيرًا منهم غير مدربين أومؤهلين للقيام بأعمال فنيـــة

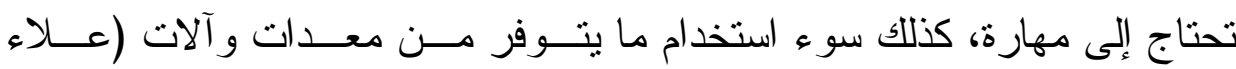

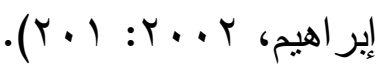

بما أن مرحلة رياض الأطفال مرحلة تربوية وتعليمية هادفة لا تقل أهمية

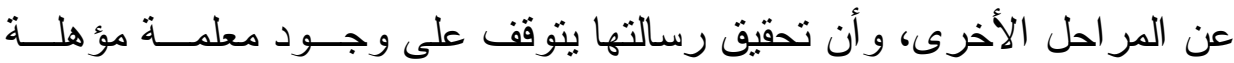

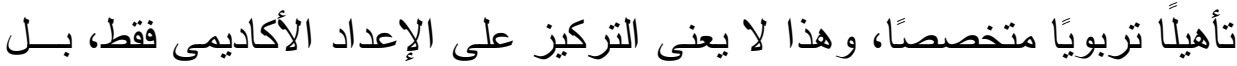

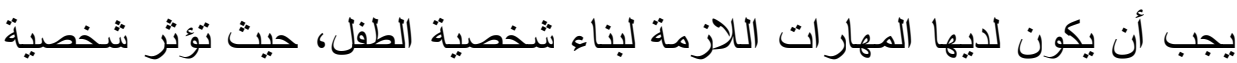

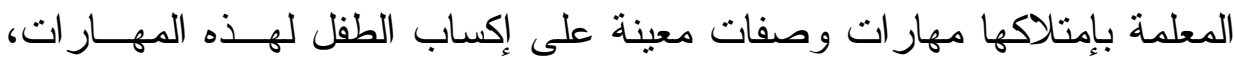

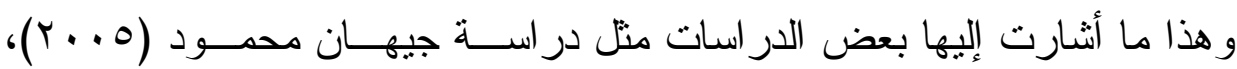

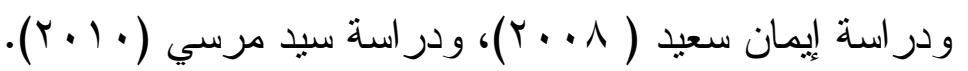

من هنا بدأت الحاجة إلى تتمية بعض المهارات اللازمة لاى المعلمة حتى

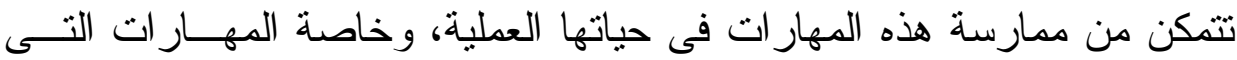


تتضمنها التتمية البشرية؛ للاستفادة من طاقاتها وتفعيلها لتحقيـق أهـــداف هـــه المرحلة، كمهارة الاتصال اللفظى وغير لفظى، ومهارة إدارة الوقـــ، ومهــارة التعزيز ، ومهارة القياس و التقويم.

يتضـح مما سبق أن تتمية العنصر البشرى من أجل تحقيق أهداف التتميــة البشرية لا تتم إلا عن طريق التربية و التعليم و التأهيل، ولهذا الــسبب فــأن أى أى نظام تعليمى يخفق فى إعداد الأفر اد للأعمال المتاحة لهح يعتبر نظامًا يفتقر إلـى التو ازن و الكفاية معًا.

\section{مشكلة البحث}

إن معتقدات المعلمة هي أفكار ها التي تؤمن بهاوتؤسس عليها ممارســاتها التذريسية فعندما تعتقد عند قيامها بالتدريس بأهمية تتويع استر اتيجيات التـدريس وتوظيف الوسائل التعليمية، و الاهتمام بالأسئلة الـــفية، وكـــللك الاســتيعاب المفاهيمي و التقويم من أجل تعلم الأطفال فهى تسعى إلى تدريس أفضل ومتطــــر و ابداعي، فالأدو ار الجديدة للمعلمة جاءت نتيجة فلسفة تربوية تهدف إلـى ربـــ المؤسسات التربوية بالمجتمع، و أصبح لازمًا على تلـــك المؤسـسـات أن تتــأثز بالتطور الذى شمل مختلف مجالات الحياة. قد أكدت در اسة عزيزة حسين (r . . r) إلى أن الطابع التقليــدى يغلـبـ على التدريس فى معظم روضات المملكة العربية السعودية ، حيث بقــوم هــذا الطابع على الحفظ و التذكر للمعلومات و الحقائق التى تقدم للطفل، يث الاهنمام بالكم وليس الكيف، دون أن يبذل أى مجهود، و عليه يكون موقف المتعلم ســليًاً فى العملية التعليمية. 
لذلك تضاعف الاهتمام بالتعلم النشط كنهج يضم عديد من أساليب الــتعلم التى تقوم على بيئة تعليمية غنية بالخبرات، وتتيح للمتعلم الانخر اط و الانــشغال النشط فى التعلم النشط و المشاركة فى تحمل مسئولية التعلم، فاستز اتيجيات التعلم النشط تجعل المتعلمين مستمتعين بالتعلم، وتتكون لديهم القــدرة علــى اكتـساب المهار ات، مما يحول العملية التعليمية إلى شر اكة ممتعة بين المعلـــم و المــتعلم، و هذا ما أكدت عليه در اسة كل من: مجدي علي (T . . ب)، فاطمة عبد الوهــاب

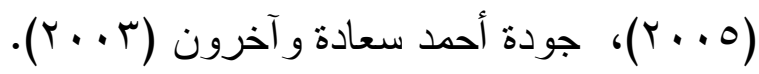
ترجع فكرة الدر اسة الحالية إلى ملاحظة الباحثة لأداء معلمات ريــاض

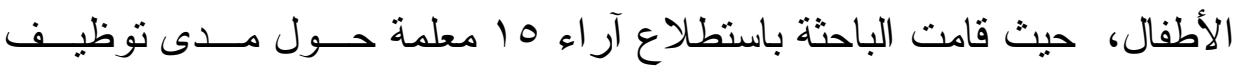
المعلمات لبعض استر اتيجيات التعلم النشط فى التـريس، وقد تبــين مــن نتــائج الاستطلاع أن المعلمات لا يوظفن استر اتيجيات التعلم النشط بالدرجـــة الكافيــة

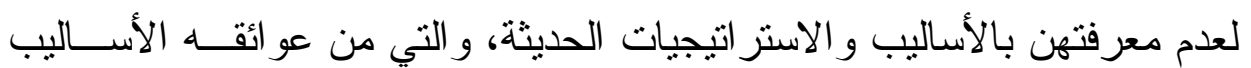
المنبعة في عملية التعليم المعتمدة على التلقين وكذللك حفظ المعلومات فقط مــن

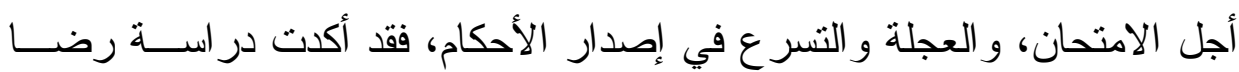
سلامة ( 9 . . r) على أن و اقع إعداد معلمات رياض الأطفال غير كاف لتلبيــة المتطلبات التزبوية المعاصرة، فقد هدفت الدر اسة التعرف على مــدى تطبيــق معايير الجودة الثاملة فى مؤسسات إعداد المعلمين بكلية التزبية، حيث أثبتت أن

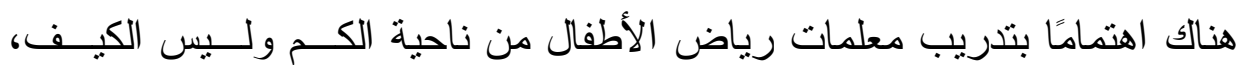
لذلك تحتاج معلمة رياض الأطفال إلى بر امج تدريبية لإكسابها المهار ات اللازمة

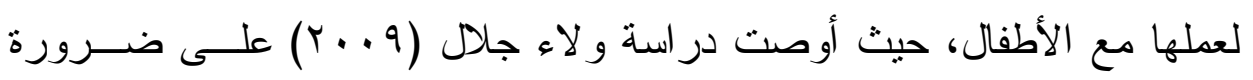
تطوير نظم وبر امج إعداد معلمات رياض الأطفال بما يتتاسب مع الواقع العملى،

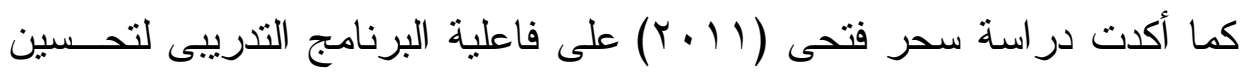


بعض أبعاد جودة الحياة لمعلمة رياض الأطفال، ودوره فـى إكــسابها بعــ الكفايات المهنية اللازمة لعملها مع الأطفال.

من أهم المهار ات التى يجب إكسابها لمعلمة رياض الأطفال هى مهــار ات التتمية البشرية، وبذلك يمكن تضمين بعض مهار ات التتمية البشرية فى بــر امج إعداد معلمة رياض الأطفال للاستفادة من طاقاتها وتوظيف إمكاناتها ( شــريف

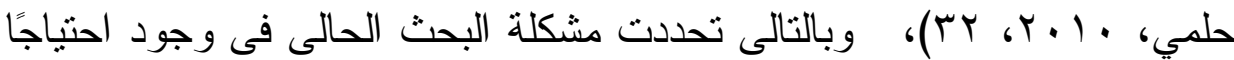
لإكساب معلمة رياض الأطفال بعض مهار ات التتمية البشرية؛ للاســفادة مسـن طاقتها وتوظيف إمكانتها، وبالتالى فأننا فى حاجة ماسة إلى بر امج تكسب هؤلاء المعلمات بعض مهار ات التنمية البشرية ، وهذا ما تسعى إلبه الدر اسة الحالية. ويمكن صياغة مشكلة الدر اسة فى التساؤل الآتي:

ما فاعلية برنامج تدريبى باستخدام استر اتيجيات التعلم النشط فــى تتميــة بعض مهار ات التتمية البشرية لدى معلمة الروضة؟ ويتفرع من هذا السؤال الرئيس الأسئلة التالية: ا - ما مهار ات التتمية البشرية اللازمة لمعلمات رياض الأطفال؟ r- ما فاعلية برنامج تدريبى باستخدام استر اتيجيات التعلم النشط فــى تتميــة مهارة الاتصال اللفظى وغير لفظى.

ب- ما فاعلية برنامج تدريبى باستخدام استر اتيجيات التعلم النشط فــى تتميــة

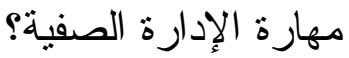
ع- ما فاعلية برنامج تدريبى باستخدام استر اتيجيات التعلم النشط فــى تتميــة مهارة التعزيز 
0- ما فاعلية برنامج تدريبى باستخدام استر اتيجيات التعلم النشط فــى تتميــة

مهارة القياس و التقويم؟

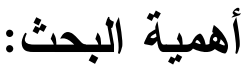

تكمن أهمية الدراسة الحالية فى أهمية الموضوع الذى تثتصى لـــه الباحثــة، حيث تتحدد:

ا - من الوجهة التطبيقية: فى الاستفادة من نتائج هذه الدراسة فـى إعـــداد

البر امج التى تسهم فى تتمية بعض مهار ات التتمية البشرية لاى معلمـــة الروضة.

Y- ومن الوجهة النظرية: قد تشكل هذه الدر استة نو اة لأبحاث أخــرى فـي مجال النتمية البشرية ومرتبطة بالتعلم النشط.

\section{أهداف البحث:}

ا - إلقاء مزيد من الضوء على بعض مهار ات التتمية البشرية و التى لابد من غرسها وتتميتها لدى المعلمة ومنها: مهارة الاتصال اللفظى وغير لفظى، مهارة الإدارة الصفية، مهارة التعزيز، مهارة القياس و التقويم.

ץ- تصميم برنامج تدريبى قائم على استر اتيجية التعلم النشط لتتميــة بعـض مهار ات التتمية البشرية لاى معلمات رياض الأطفال. ب- التعرف على فاعلية البرنامج من خلال قياس الفـروق بــين متوســـى درجات المعلمات عينة الدر اسة فـى القياســين القبلــى و البعـــى لهــذهـ المهار ات البشرية على بطاقة الملاحظة.

المجلد الخامس


ا- البعد المكانىى: ويقصد بـه المكان الذى أجريت فيــه الدر اســــة التطبيقيــة

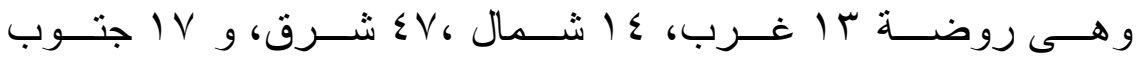

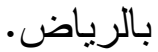

ץ- البعد البشرى: اقتصرت عينة الدر اسة على المعلمات بالروضات الـسابق ذكر ها، وقد تكونت عينة الدر اسة من (·r) معلمة.

ب - البعد الزمنى: يشمل الفتزة الزمنية المخصصة لكل نشاط، وقد تم تطبيــق

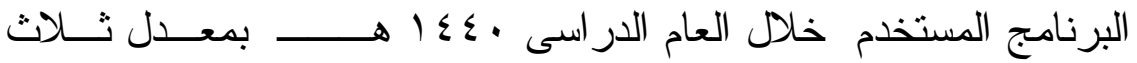
جلسات أسبو عيًا لمدة أربعة أسابيع.

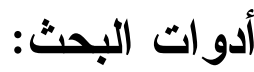
استخدم فى هذا البحث الأدوات التالية التى أعدتها الباحثة: بطاقة تقدير مهار ات التتمية البشرية. ( إعداد الباحثة).

برنامج تدريبى باستخدام بعض استز اتيجيات التعلم النشط لتتميــة بعـض مهار ات التتمية البشرية. (إعداد الباحثة). على ذللك فإن نتائج البحث الحالى ترتبط بهذه الأدو ات، وكذلك بمو اصفات العينة التى سوف يتم تطبيق هذه الأدوات و البرنامج عليها، و وهــذه المهـــار ات

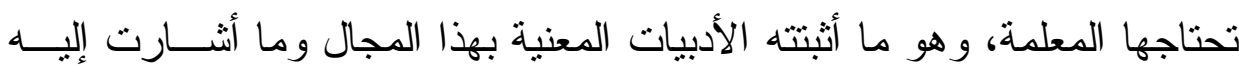
البحوث و الدر اسات السابقة. 


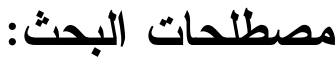

التعلم النشط

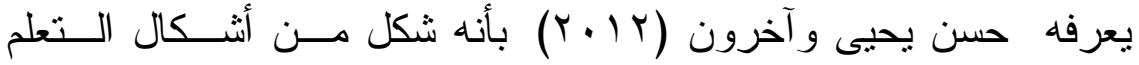

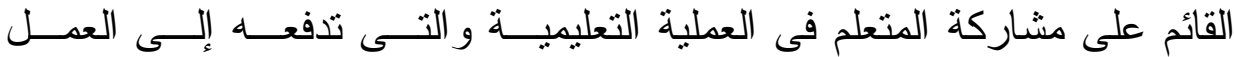

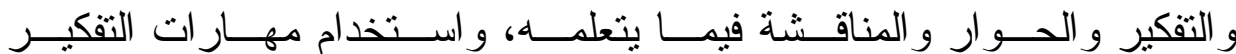

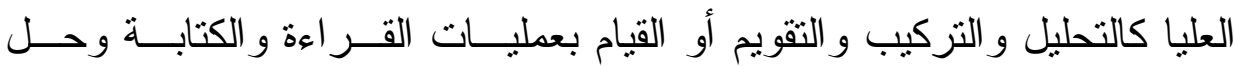
المشكلات. تعرف الدراسة الحالية استر اتيجية التعلم النشط إجر ائيًا بأنها الاستر اتيجية

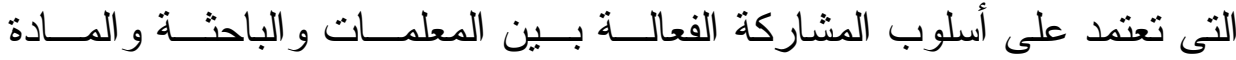
العلمية من خلال ورش عمل تدفعها إلى المناقتشة و الدوار، ويمكن تطبيق هـــا

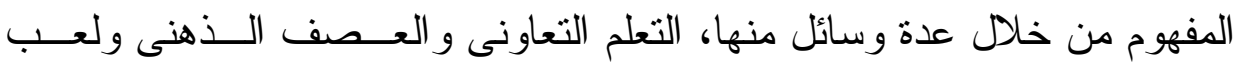

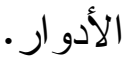

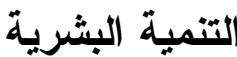

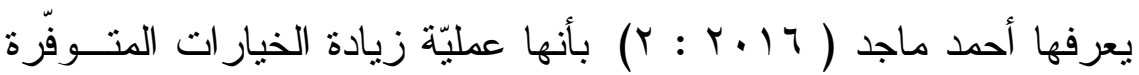

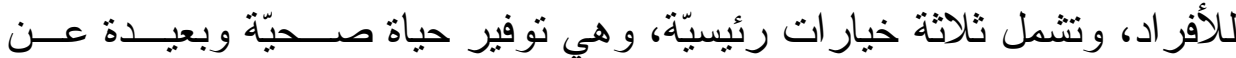

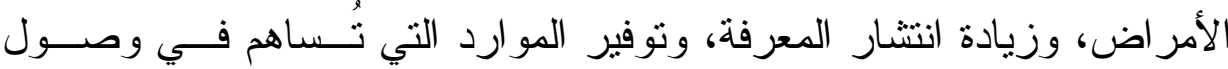

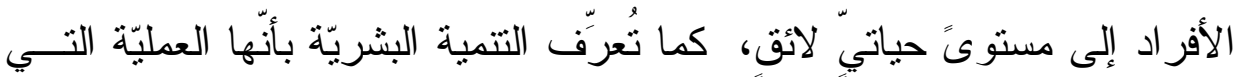

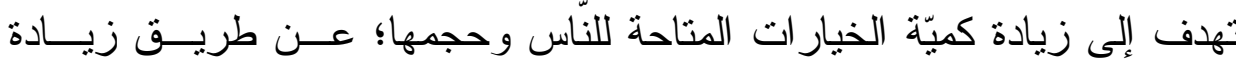

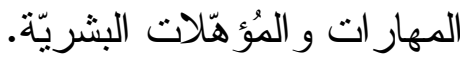


تعرف الدر اسة الحالية التتمية البشرية إجر ائيًا بأنها عملية تتمية القـدر ات الإنسانية المتمنلة فى الاتصـال اللفظى وغير لفظـى و إدارة الـــف و التعزيــز و القياس و التقويم لدى معلمات الروضة بكليات رياض الأطفــال، ـــن خــله توفير فرص ملائمة للتعليم وتتمية الخبر ات الإيجابية و التخلص مــن الخبـر ات السلبية، وتحديد الأهداف و السعى لتحقيقها باجنهاد، لخلق أفر اد ناجحين نـــافعين لأنفسهم ولمجتمعهم.

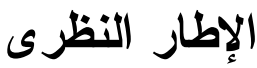
المحور الأول: التعلم النشط واستر اتيجياته مفهوم التعلم النشط

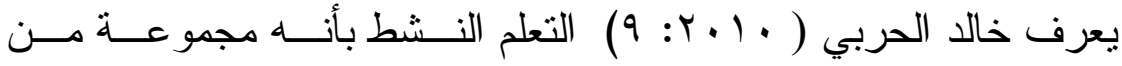
الاستر اتيجيات التي يتعلم الطالب داخل غرفة الصف بحيث تجعله مُناقداً للمشاركة و التفكير فيما يؤديه وذللك بإثر اف وتوجيه، ومتابعة من قبل المعلم. التعلم النشط من منظور البنائية

تعتمد فلسفة التعلم النشط على النظرية البنائيــة، و البنائيـــة فــى أبــسط توصيفاتها: هى أن يينى المتعلم معرفته من خلال تفاعله المباثر مع مادة الــتعلم وربطها بمفاهيم سابقة و إحداث تغيير ات بها على أساس المعــانى الجديــدة بمـــا يتحول إلى عملية توليد لمعرفة متجددة، على أن يدعم المتعلم ما بناه بحــوار ات

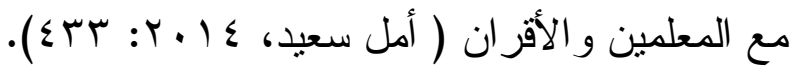


عناصر التعلم النشط

( جودة أحمد وزملاؤه Y . . . O O أن للتعلم النشط أربعة عناصر هي.

Talking and listening Element 1

"أنا أحتاج أن أنكلم" أو "أنـا أنكلم من تفكيري"، فهذا يعني أن ما نفعله هـــو

تشكيل مجموعة كبيرة من الأفكار التي تدور في عقولنا، وهذا ما يجعل الطلبــة

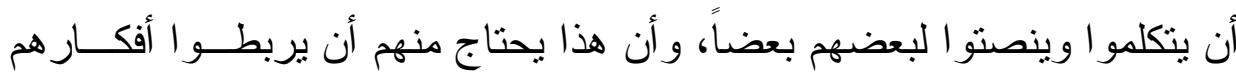
بشكل جيد و يعملو ا على تتظيم خطو ات تقكير هم.

Writing Element عنصر الكتابة

الكتابة توضـح ما يفكر به الفرد، تماماً منل عنصر الكــلام أو الحــديث، فالكتابة تسمح النا بأن نكتشف أفكارنا و نتوسع فيها، كما أن الكتابة عامل مهــ للتعلم النشط، وذلك عندما يغوص الطالب في أعماق تفكيره هو ويعهـل علــى تتميته للنهوض به.

reading element عنصر القراءة

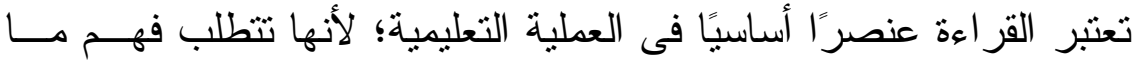
يفكر به الآخرون،و لذلك يصعب على الطلبة فهم القر اعة الناقدة التـي تتطلـبـ التأمل ، وتجميع الأفكار، وتلخيص المعلومات،وربط الأحداث وفهــم الرســائل المخفية و غير ذلك. 
ع - عنصر التأمل والتفكير: Reflecting Element

إن فتر ات الهدوء مهمة للمتعلم ليقوم بالتأمل في ذاته وما يدور حوله مسنـ

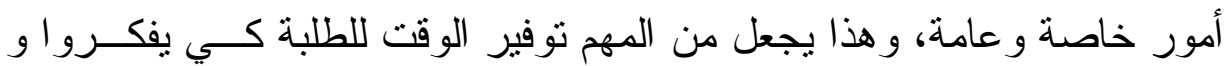

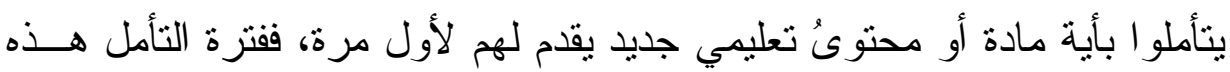

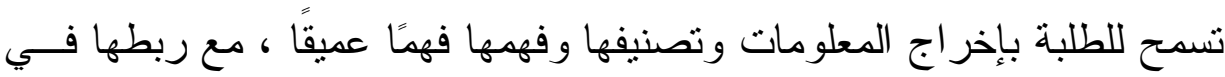

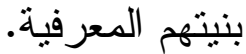

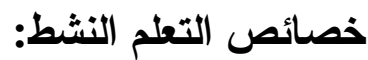
تتمحور خصائص وسمات التعلم النشط في النقاط الآتية:

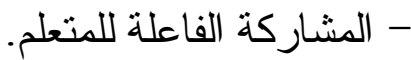
- التركيز على كيفية تطوير مهار ات التعلم الأساسية المتقدمة وتتميتها أكثر من

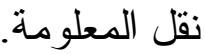
- توجيه المتعلم لاستخدام مصادر متعددة ومختلفة رئيسة و أولية. - التأكيد على إيجابية المتعلم في مهار ات و استر اتيجيات التقكير العليـــــــل منل التحليل و التركيب و النقييم وحل المشكلات. - توفير بيئة تعليمية فعالة ومناسبة بإناحة الوسائل و الأساليب التعليمية المختلفة و التي تتناسب مع فروق المتعلمين لينه

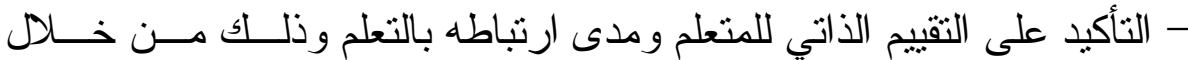
تحديد معيار الحكم على العمل و الهدف منه للمتعلم ( نهـى در اج، 9 . . ب: .$($ YVT 


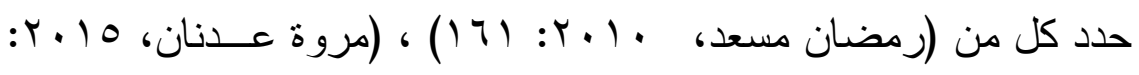

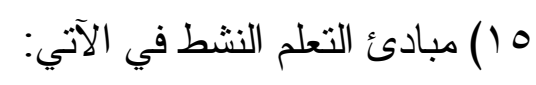

- تطوير مهار ات الطلاب العقلية ونتميتها وتفعيل مهــار ات التفكيــر العليــا:

$$
\text { التفكير الناقد و العمل الإبداعي (حل المشكلة). }
$$

- انتتر الك الطلاب في اختيار نظام العمل و الموقف التعليمي و الأنشطة و المهام

$$
\text { بفاعلية و إيجابية. }
$$

$$
\text { - - الخبر - ات - المبألوفة جسور للخبر ات الجديدة (نقل التعلم). }
$$

أدوار المعلم والمتعلم في التعلم النشط:

$$
\text { أولًا : دور المعلم في التعلم النشط : }
$$

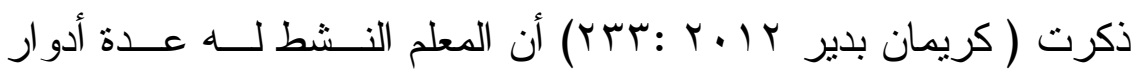

$$
\text { أ- دور المعلم النشط كملاحظ ومشخص ومعالج: }
$$


من أدوار المعلم النشط في العملية التعليمية دور الملاحظ فكفاءة المعلـــ تعتمد إلى حد بعيد على قدرته على ملاحظة طلبته عن قرب وملاحظة أفعـالهم ودور ها وتفاعلها وبناء على ذلك يكون فكرة متكاملة عن طبيعة طلبته وتكوينهم السيكولوجي. ب- - دور المعلم النشط في إكساب الطلبة المهار ات المختلفة: يعد هذا الدور ذا أهمية كبيرة في إكساب الطلبة المهــار ات و إعــدادهم للحياة العملية و لأن هذه المهار ات متتوعة فهنالك مهــار ات عقليــة و اجتماعيــة و أكاديمية تعتمد على المهار ات العقلية التي تدعم قدرة الطالــب علـى التفكيــر العلمي السليم ومنها مهارة: الملاحظة ، التصنيف، القيــاس، الاتــصال، جمــع البيانات، الاستتناج، استخدام علاقات المكان و الزمان، و المهـــار ات الأكاديميـــة

$$
\text { و اليدوية و الاجتماعية. }
$$

ج - دور المعلم النشط في إثز اء بيئة التعلم:

للحصول على بيئة تعلم خصبة وشيقة وممتعة للمتعلم فإن المعلـــم يقـوم

بدوره في الثرح ويقوم الطلبة بدور هم في الاستماع و الاتــصال، وهــــه البيئـة

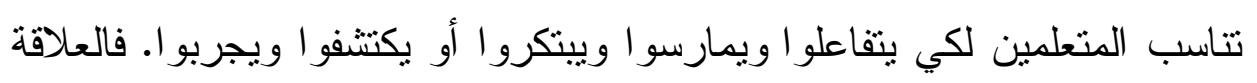

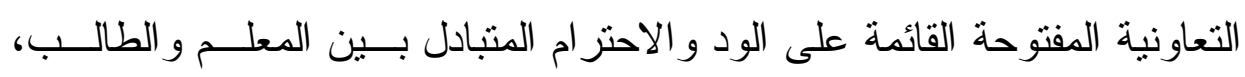
تسمح للمعلم باءثز اء بيئة التعلم وتحقيق التعلم النشط. ثانيا: دور المتعلم في ممارسة التعلم النشط:

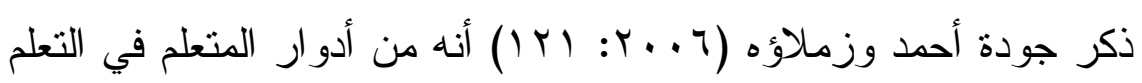




$$
\text { حتر ام آر اء الآخرين وتقدير قيمة نبادل الأفكار . }
$$

حالمشاركة في الخبر ات التعلمية المنتو عة الرسمية وغير الرسمية.

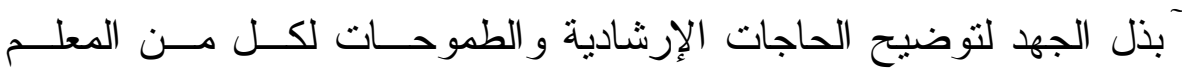

$$
\text { و المرشد النفسي. }
$$

فَهم المتعلم لذاته و أن نموه وتطوره و استقلاليته كفرد يبدأ منها أولًا.

تقفبل المتعلم للتوجيهات و المقترحات و التقييمــات مـن المسـؤولين بحـب

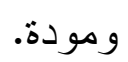

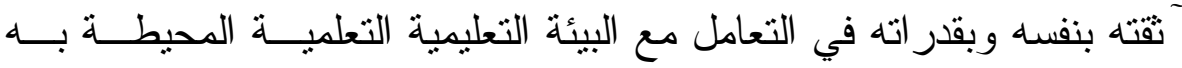

$$
\text { بنجاح. }
$$

توظيف المعارف و المهار ات المكتسبة في الحياة العطلية لتحسين التعلم.

$$
\text { استر اتيجيات التعلم النشط }
$$

توجد استر اتيجيات تعليمية عديدة للتعلم النشط، وتستخدم في المؤسـسات

$$
\text { التعليمية، و التزبوية، ومنها: }
$$

$$
\text { استر اتيجية النقاش }
$$

هى من أحد الاستراتيجيات التعليمية المهمة في التعلم النشط، و التى تعتمد

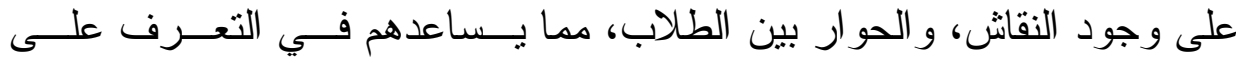

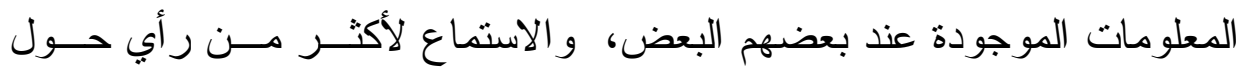

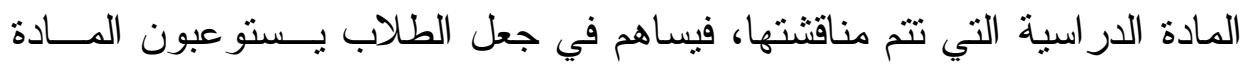

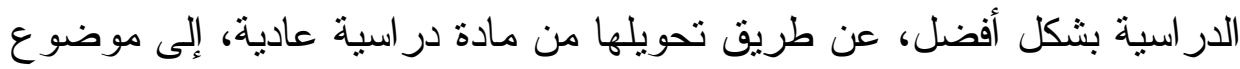


حواري يهدف إلى جعل كل طالب يتعرف على المادة الدراسية بأسلوب بـسيط،

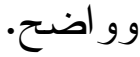

\section{استر اتيجية العصف الذهني}

هى استر اتيجبة تعلم نشط تساهم في تحفيز الطلاب للمشاركة في الحصة،

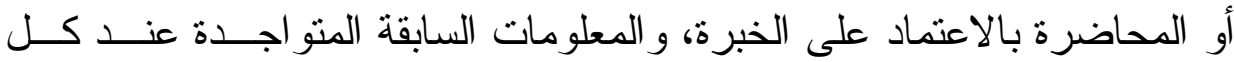

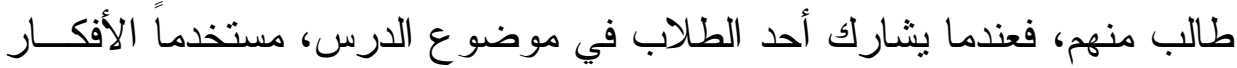
التي يعرفها، يساهم ذلك في تحفيز باقي الطلاب للمشاركة، و التعبير عن آر ائهم،

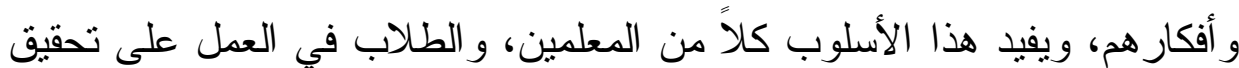
الأهداف المرتبطة بالمادة الدراسية.

استر اتيجية حل المشكلات

هى استر اتيجية تعتمد على جعل الطلاب يو اجهون مشكلةً، أو موقفاً مــا،

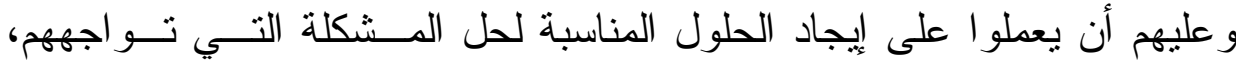

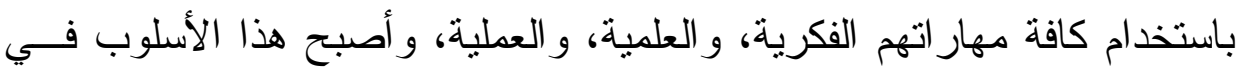

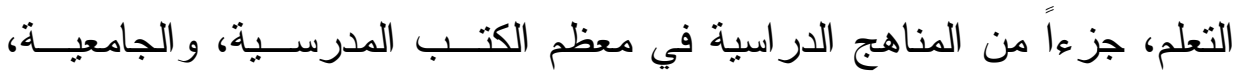
ويسمى أيضاً باسم (التفكير الناقد)، و الذي ساعد على تلى تطوير مهار ات الطـــلاب،

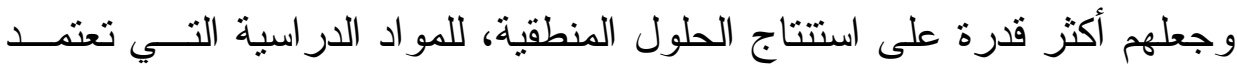

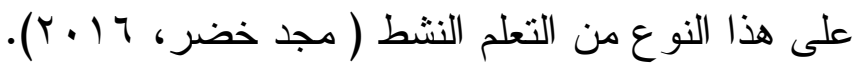
استر اتيجية التعلم التعاونى

هى استر اتيجية تدريسية، يتعلم فيها الطلبة من خلال العمل فى مجموعات

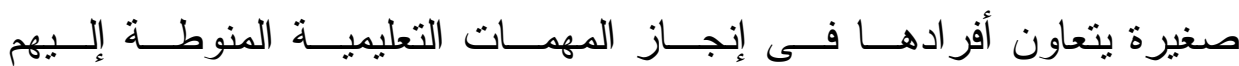

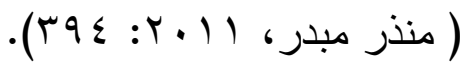




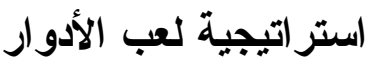

يعرفه الجلاد:" بأنه طريقة تعليمية تقوم على تمثيل موقف يمثـل مسـشكلة

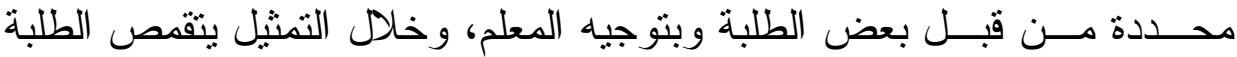

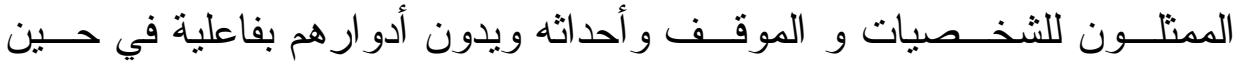

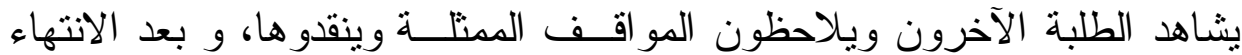

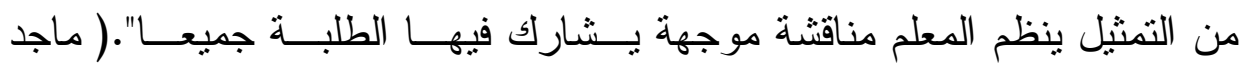

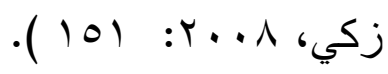

هور المعلم في طريقة لعب الأدو ار وتتمية التفكير

- نوجيه أسئلة مفتوحة أو مغلقة لمعرفة ملائمتها ومناسبتها للموقف التعليمي.

- توجيه أسئلة ترفع مستوى التجريد وأخرى تخفض مستوى التجريد حسسب

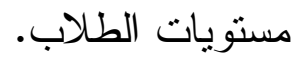

- توجيه أسئلة تربط بين المفاهيم المتضمنة في الموقف التعليمي الـــي يــتم تمثيله.

- تلخيص آر اء الطلاب وملاحظاتهم حول النموذج الذي يتم تمثيله. - القدرة على الاستخدام البنائي للأفكار لدى الطلاب من خلال: "صياغة الأفكار -عقد المقارنات- الموازنة بـين مــصادر المعلومــات-

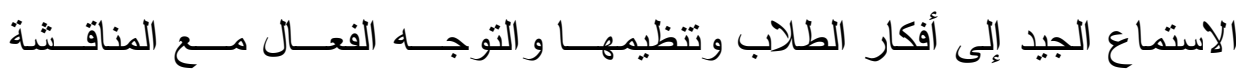

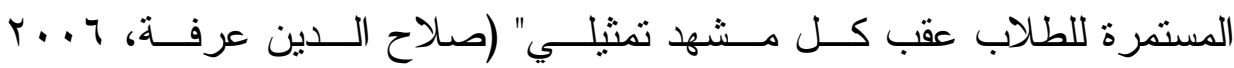
.$(\xi \cdot 0-: \leqslant \cdot 4$

المجلد الخامس




\section{استراتيجية المساجلة الحلقية}

استر اتيجية الماسجلة الحلقية تسهم فى تتمية قدرة المتعلمين علــى البنــــاء

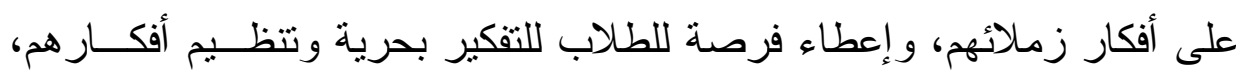
وهى تمنل أحدى استر اتيجيات التعلم التعاونى النشط، وتستخدم هذه الاستر اتيجية

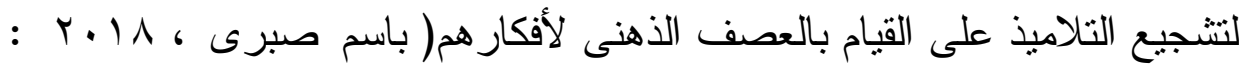
. ( «Or يرى (Kaleigh,2013) أنها استر اتيجية تعاونية طورها كاجــان، حيـــ يقسم فيها التلاميذ إلى مجموعات صغيرة (ع - آ)، حيث يوجه المعلم سؤلًا متعدد

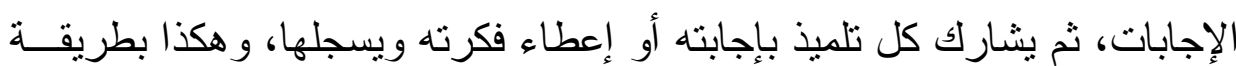
تدويرية إلى أن يشارك جميع التلاميذ بأفكار هم. • دور المعلم فى استر اتيجية المساجلة الحلقية

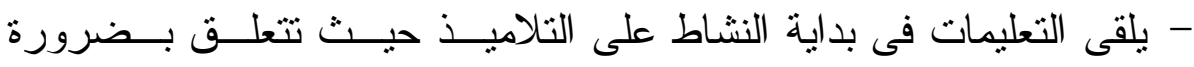
الاستماع للأسئلة ومشاركتهم فى الإجابة عنها، و عدم النقد و التقييم لأفكـار زملائهم، و الالتز ام بخطو ات الاستر ومنات التيجية.

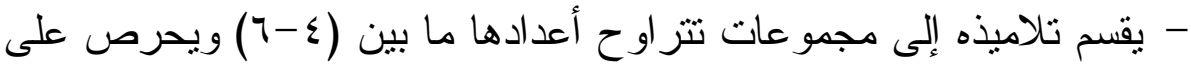

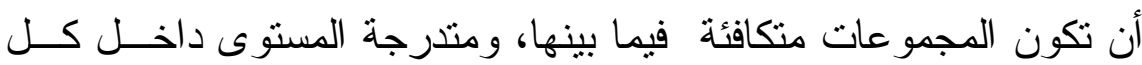

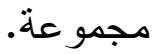

- يطرح المعلم المشكلة أو السؤال أو القضية أو يكتبها على السبورة أو على ألى ورقة ويوز عها على المجموعات. - بطلب من التلاميذ البدء فى التفكير فى المشكلة أو القضية أو السؤال. 
- بطلب من تلميذ تسجيل رأيه أو فكرته داخل ورقة النشاط المحددة. - بعد انتهاء التلميذ من تسجيل فكرته أو رأيه يطلب منه تمرير نفس الورقـــة إلى التلميذ الثانى إلى أن تدور على جميع التلاميذ فى المجموعة، ويضيف لنه كل منهم رأيه أو فكرته.

- يطلب من التلاميذ عرض الأفكار و الإجابات على الجميع ومناقثتها (باسم

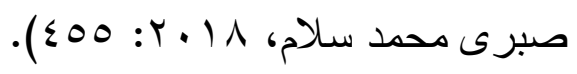

استر اتيجية المقابلة ثلاثية الخطوات

أن استر اتيجية الدقابلة الثلاثثية الخطوات من استر اتيجيات التعلم التعساوني

التي وضع خطو اتها العالم (Kagan) اذ انها توفر التفاعل المتسلسل للمتعلمين ،

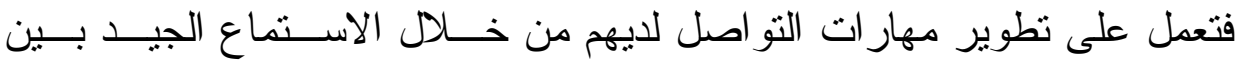
الثركاء ، وتمثيل أفكار هم للآخرين، كما أن هذه الإستر اتيجية تطور الدهـار ات اتل الثخصية و الاجتماعية بما في ذللك الاستماع و الفهم و المسؤولية، وتستخدم هــــه

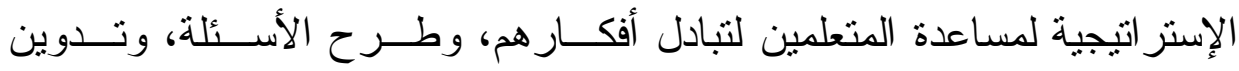
ملاحظاتهم وباستخدام هذه الإستر اتيجية ، يمكن للمتعلمين التمتع بالكلام، لأنهـ

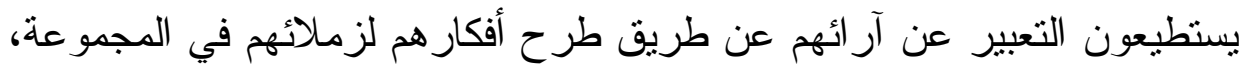

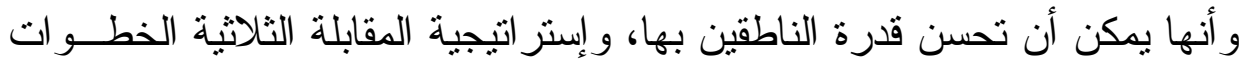
هي تعلم تعاوني تساعد المتعلمين للعم جهودهم في التعلم الذاتي و الاستماع إلــى الـى

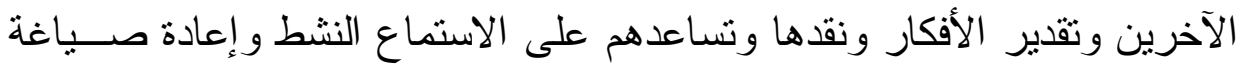

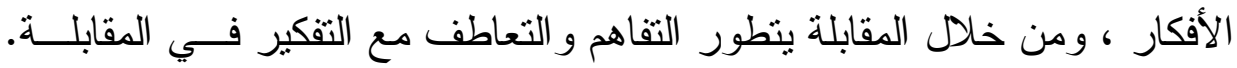

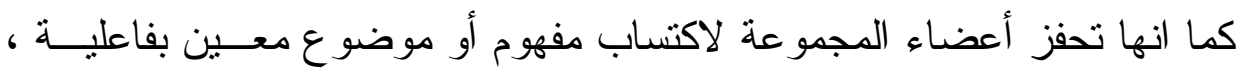

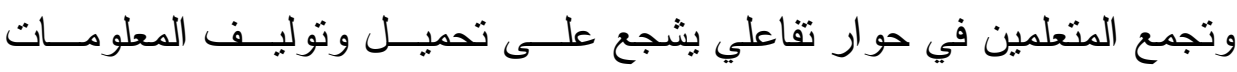

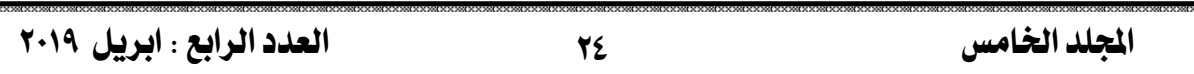


الجديدة، كما أن هذه الإستر اتيجية قابلة للتكيف في الصفوف الدراســية (هـدى

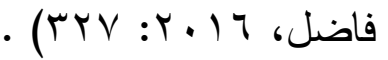

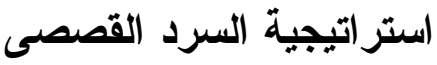
• أهداف التي تحققها القصة:

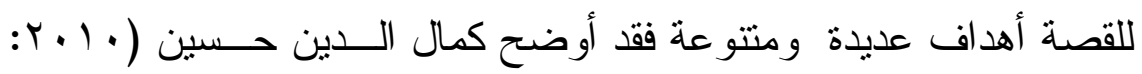

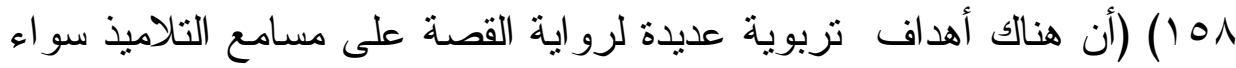

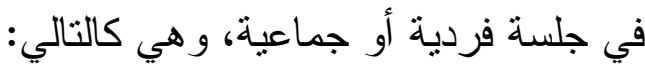
(تتمية مهار ات الاستماع، ومهار ات الحديث، مهار ات القــر اءة كالكتابــة، تتمية وتتجيع الخيال و التخيل، الاتجاهات الايجابية نحو الكتاب كالقر اءة، تساعد

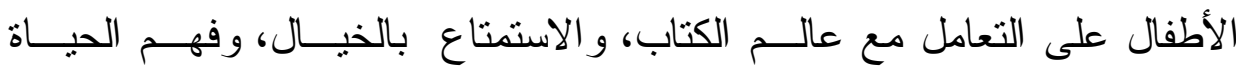
ومو اقفها، ووعى الطفل بذاته وبالآخرين، وعلى المشاركة بالخبرات، وزيــادة القاموس اللغوى، و إثر اء المشاعر ). المحور الثانى: معلمة الروضة والتنمية البشرية تُعدّ رياض الأطفال القاعدة الأساسية لمر احل التعليم المختلفة؛ فيها تقــدم الأصول الأولى، و الأسس الراسخة النى تقوم عليها العملية التعليمية الدة صصودة

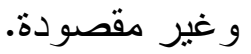

معلم الروضة لابد أن يكون مبدعاً فى البداية، لكي يكون قادراً على تتفيذ

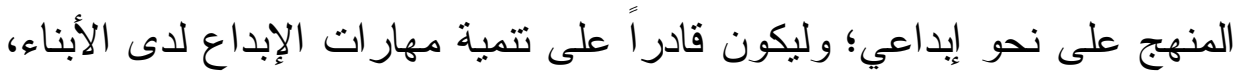

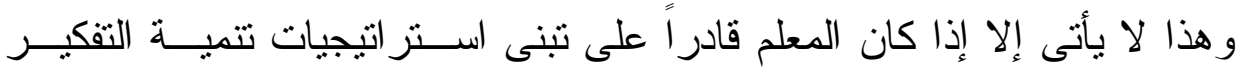
الإبداعي التى تؤكد على أهمية استخدام عديد من استراتيجيات التدريس المناسبة التهان 
لما يوجد من فروق فردية يين التناميذ، ومر اعاة التقاعلات الإنسانية التى يجــب أن تسود مو اقف التذريس بمختلف أنو اعها ومستوياتها، فالمناخ الصفي التسلطي لا يساعد على التدريس المبدع، و لا يؤدي إلي اكتساب مهار ات الإبداع، ومن ثم فالحاجة كبيرة إلى المناخ الطبيعي الذي يشعر فيه الطفـلـل بالحـب، و المـــودة، و الصداقة، وحرص المعلم على تعليمهاوتزبيته علــى نحـــو متميـز ( إبــر اهيم

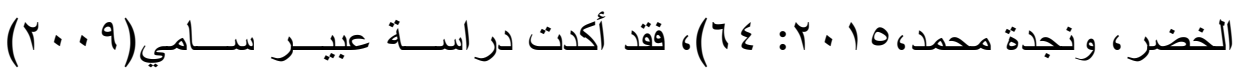
ضرورة بناء بر امج تدريبية لإعداد معلمة رياض الأطفال وتدريبها فـى ضـــ ء

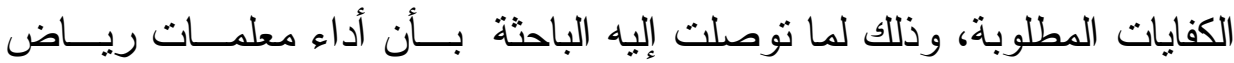
الأطفال فى مجال العلاقات الإنسانية لتتفيذ وحدة الخبــرة، استـشعار الدافعيــة، الأهداف التزبوية، التقويم قد كان دون المستوى المطلوب.

• الخصائص الشخصية لمعلمة الروضة

إذا رجعنا إلى الأدو ار التى تقوم بها المعلمة، و المهام التى تؤديها بالنـسبة لأطفال؛ لأدركنا أن وظبفتها غير مقصورة على التعليم، بل هي مربية بالدرجــة الأولى، و لا يتوقف تأثير معلمة الروضـة فى الأطفال على مهار اتهــا، و إتقانهــا

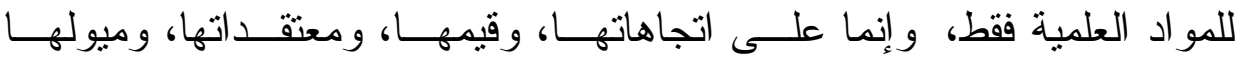
الشخصية، و المنل الأعلى ( هدى محمود ، • ( • ب: 0 1) ، ويتوقف على معلمــة الروضة تحقيق أهداف التزبية فى رياض الأطفال، فمحرر عمل المعلمــة فـى الروضة هو الطفل، وبما تحمله من مكونات شخصية، و عملية، وثقافيــة تعتبــر

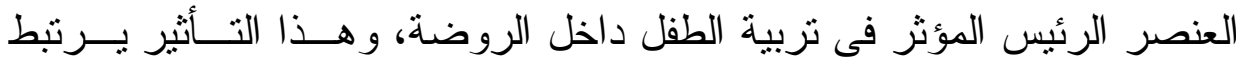
بمهار اتها الفنية فقط، ولكنه برتبط كذلك بما تحمله من اتجاهات، وقيم، ومشاعر

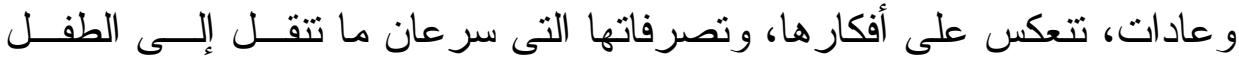


باعتبار ها القدوة و النموذج الذي يقلدونه، وقد ينقصون شخصيتها فى تصرفاتهم

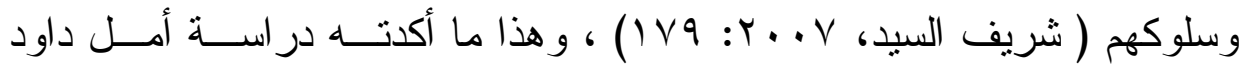

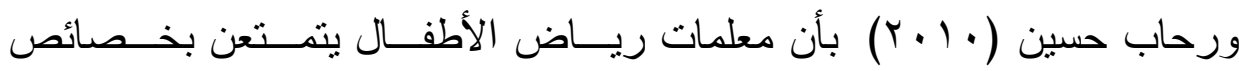

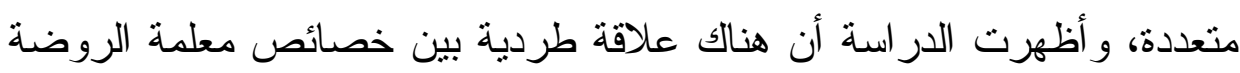

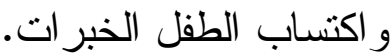

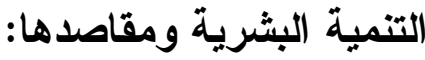

التتمية البشرية محورها الإنسان، حيث تهدف إلى رفع مستوى الحياة إلى

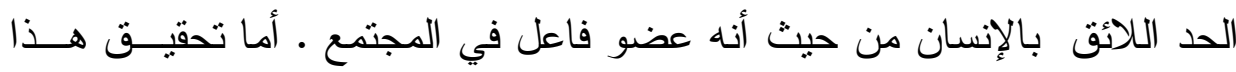

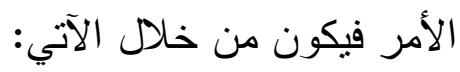

$$
\begin{aligned}
& \text { 1- توفير فرص التشغيل وكسب الدخول. } \\
& \text { r- نتمية القدر ات التعليمية. } \\
& \text { ب- (السلامة الصحية. }
\end{aligned}
$$

ع - توفير سياسة حماية اجتماعية لا سيما للفئات الاجتماعية الو اقعة علىى

$$
\text { الدرجات الدنيا و الوسطى مَّن سلمَّ الدخل. }
$$

0- إيجاد شبكات أمان اجتماعي، وهي نوع أساسي من أنــو اع الحمايـة

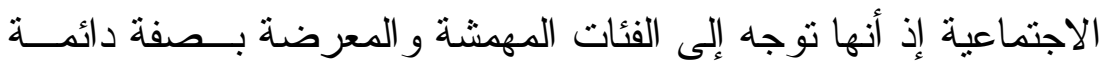

\begin{tabular}{|c|c|}
\hline العدد الرابع : ابريل 19 •r & TV \\
\hline
\end{tabular}

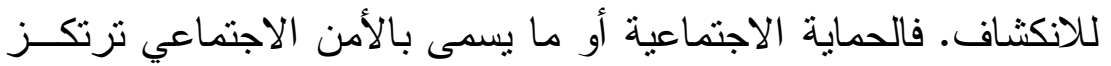

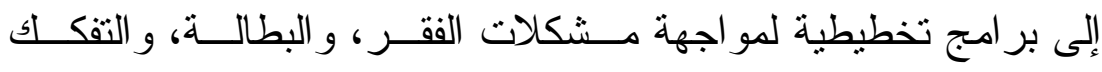

الاجتماعي، و الأمية، و الجهل، و المرض، لهو الهه والخروج عن القانون، إلى ما 
هنالك من الأمور المساعدة على التوترات الاجتماعية وتداعياتها السلبية

$$
\text { مهار ات التنمية البشرية ( محمد مر اد، (1) بr: 1). }
$$

1- مهارة الاتصال اللفظية والغير لفظية:

الاتصال هى عملية تبادل المعلومات من خلال شخص يرسل المعلومسـات بطريقة لفظية أو غير لفظية إلى شخص آخر يستقبل هذه المعلومات، وهو بذلك بلك الكال يعد قو ام و أساس الحياة؛ لأن العالم الذى نحيا فيه قائم على التو اصل، فهى عملية

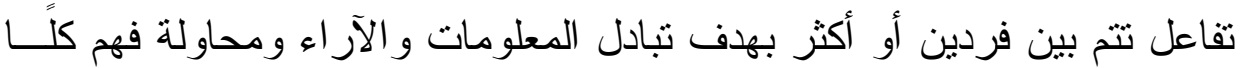
Haji Z. et ( منهم لمشاعر ووجهات نظر الآخر بهدف تحقيق الاتصـال الفعسال .(al, 2011: 72

إذن نستتتج أن عملية الاتصال لا تسير في اتجاه واحد بل في اتجــاهين،

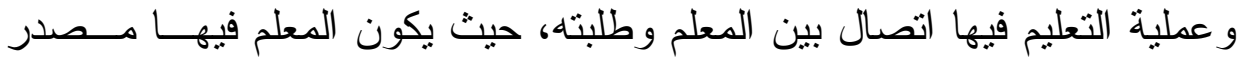
المعلومات و الطلبة مستقبلين لها، و هناك وسط (قناة اتصال) بينهما يتم بو اســـته

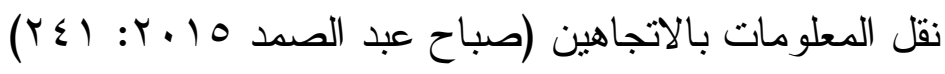

\section{Verbal Communication الاتصال اللفظي}

لقد اهتمت النظريات اللغوية الحديثة بالتفسير العلهـي للغـــة ووظائفهــا،

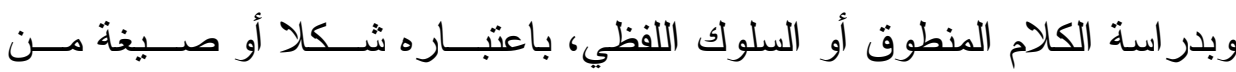
السلوك الإنساني، فعن طريقه يتم النتواصل، و الحكم على جـودة الــسلوك، إذن اللغة نسق من المعلومات و الإثشار ات هدفها التو اصل، خاصة أثناء اتحاد الـــال

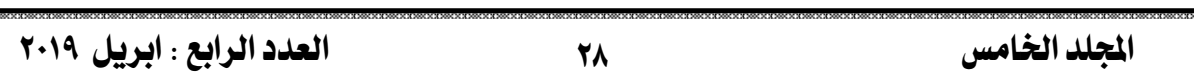


مع المدلول بنيويا، أو تقاطع الصورة السمعية مع المفهوم الذهني. (بسام عبد الهه $\cdot\left(r: r \cdot 1 r^{\prime}\right.$

\section{ميار ات الاتصال اللفظي Verbal communication skills} ومن أهم المهارات التي سبتناولها البحث الحالي ما بلي:

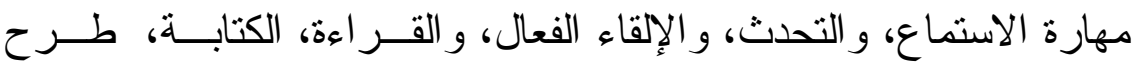

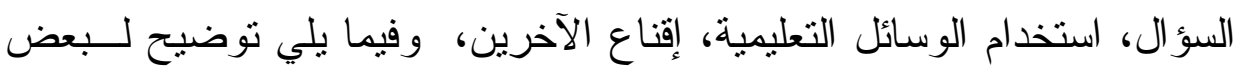

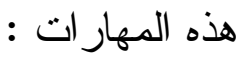

\section{مهارة الاستماع Listening Skill}

تمنل مهارة الاستماع الوجه الآخر لمهارة الحديث، ومنهما معـا يتحـدد

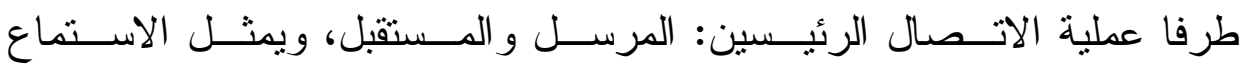

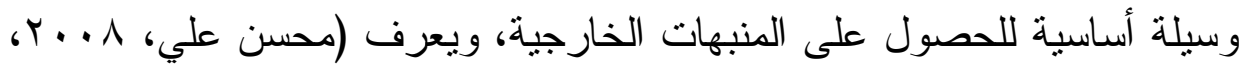

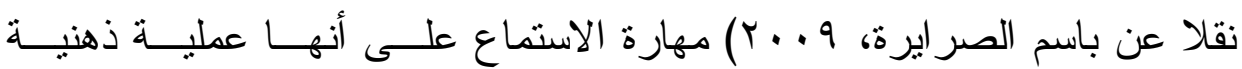
و اعية ومقصودة لتحقيق غرض معين تشترك فيــهـ الأذن و الــدماغ، إذ تـستقبل

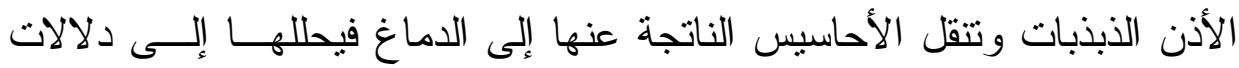

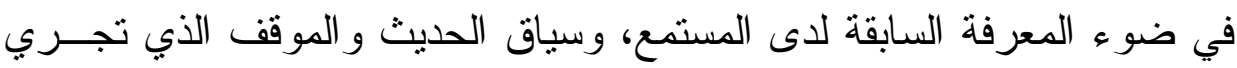

\section{ץ - Speaking Skill مهارة التحدث}

تتضمن سلوك المعلم في أثناء الإلقاء من طلاقة فـي اللـسان، وصـــة

مخارج الحروف، و الضبط السليم لحركة كل حرف، واستخدام الرموز اللفظيــة الملائمة لمستوى عمر ونقافة وقدرات المنلقي الخاصة، و النتويع فـي درجــات 
الصوت مع مر اعاة البطء و السر عة أثناء التحدث و الحديث بما يتتاسب و الموقف

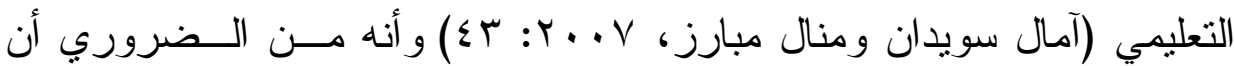
يركز المتحدث على فكرة وحيدة وتضمينها بيانات مرئية و اضحة لدعم التعليـق

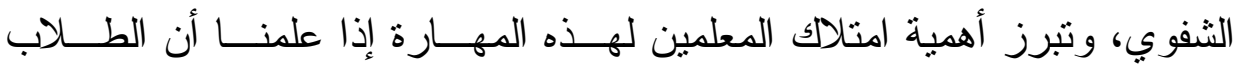
يصرفون على الأقل (0٪\%) من يومهم المدرسي منشغلين في استماع النشاطات التعليمية ، وأن ( •0 \% - . 9 \% ) من المعلومات المتعلمة تكتسب مــن خــلال

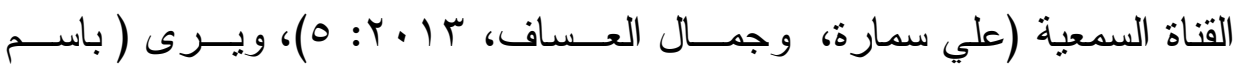
الصر ايرة و آخرون، 9 . . ب) أن يمتلك المتحـــث مجموعــة مــن المهــار ات و القدر ات لضمان وصول الرسالة على الوجه الأكمل.

\section{ب - مهارة (الكتابة}

تعد تتمية مهار ات الكتابة الأساسية مطلباً تعليميــاً مهمــاً لــدى جميــع المتعلمين، وفي المر احل الدر اسية الأولى على وجه الخــصوص، إلــى جانــب

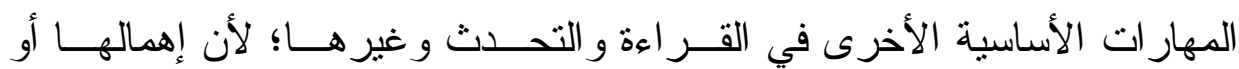
الضعف فيها سوف يستمر مع المتعلم في المر احل المتقدمة، وللمعلــم وطريقــة

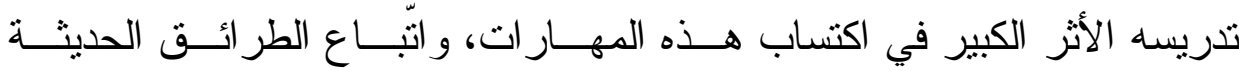
و الاتجاهات المعاصرة في تعليم الكتابة، من شأنه أن يرتقي بمستوى المتعلّمـين في الكتابة، مع ضرورة الاهتمام بفردية المتعلم وشخــصيته و إعطائــهـ الــدور الأكبر في العملية التعليمية؛ لأن الكتابة إنتاج فردي، يعتمد على ذاتيــة المــتعلّم

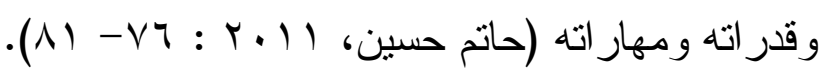




\section{ع - مهارة اقناع الآخرين}

للأشخاص الذين يسعون للفوز بما بريدون يحاولون جاهدين إتــــان فـنـ

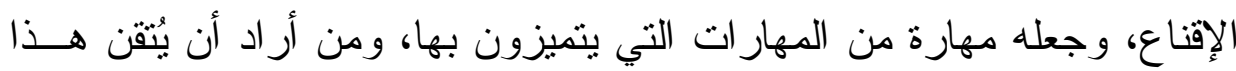

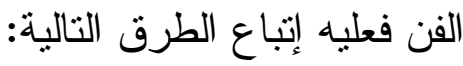
1- يبدأ إقتاع الآخرين بالهصداقية الصادرة من المُقنع. r- أن يكون موضوع حديثه بعيداً عن أهو اء ورغبات الفرد الثخصية.

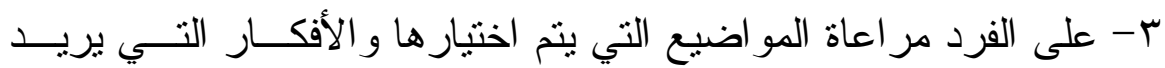
طرحها للآخرين، ويتحرّى المصداقية في ذلك. ع - الثقة بالنفس وبقدر ات الفرد و إمكانياته، وما لديه من مهار ات. 0- مو اجهة الخوف، فجميع العظماء الذين يتميزون بقدرتهم العاليــة علـى

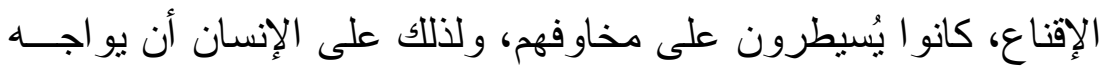

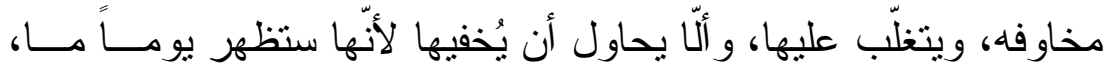

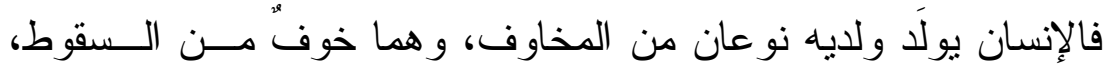

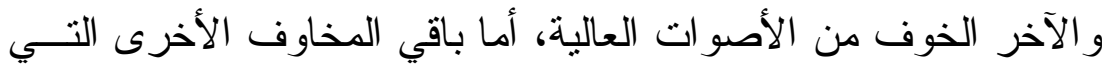
نظهر عليه بعد ذلك، فهي مخاوف مكتسبة.

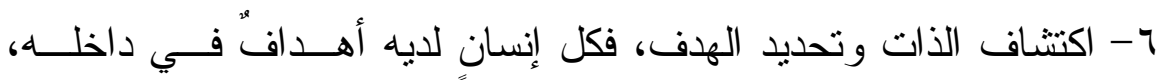
وطاقاتُ كامنةٌ، و أفكارٌ ر رائعةٌ. V- تقدير الذات؛ حيث أثنتت الدر اســات أنّ مــن لــديهم تقــدير" لــذو اتهم

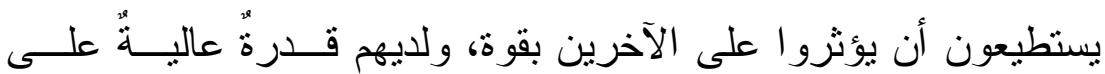

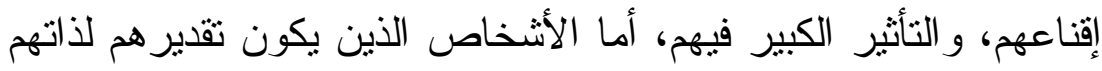


منخفضاً، أو غير صحي، فإنّ هذا ينعكس على نجاحهم وتأثنير هم علـىى

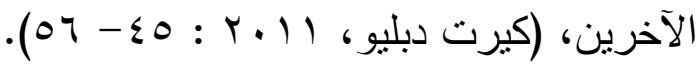

$$
\begin{aligned}
& \text { Y - مهارة إدارة الصف الدراسى: }
\end{aligned}
$$

تعد إدارة الصف القاعدة الرئيسية التي تتطلــق منهـــا عمليــة إصـــلاح

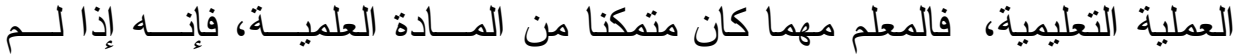
يمتلك مهار ات إدارة الصف ويهيئ لنفسه البيئة الصفية المناســبة لــن يـستطيع

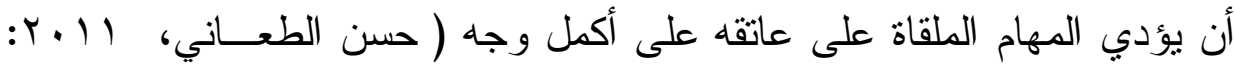

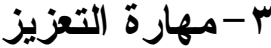

التعزيز سلوك لفظي أو غير لفظي، يأتي عقب السلوك سواء كان لفظيــا

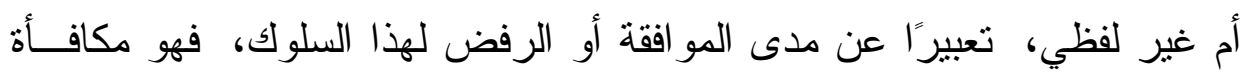
بعد نجاح، أو عقاب بعد خطأ، يخطئ كثير من المعلمين حينما يقصرون مفهــوم

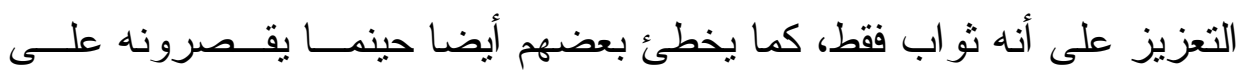

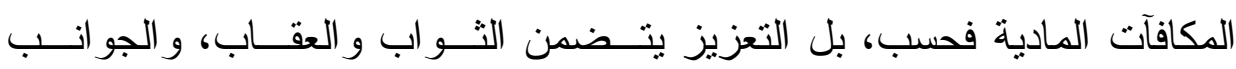

$$
\text { ع - مهارة القياس و التقويم و المادية ( أحمد حسن، V V . Y). }
$$

الإجراءات التى من خلالها يسنطيع المعلم المتخصص في التقويم، التقييم

من جمع وتقديم معلومات منظمة وموضوعية حــول التلميــذ أثتـــاء التعلــيم أو التكوين بالاعتماد على العديد مــن التقنيــات مثــل الاختبـــار ات و الامتحانــات و الماحظة و السجلات، وذلك من أجل التعرف على مدى تحقيق العملية التعليمية

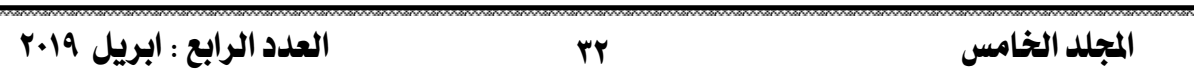


للأهداف المرجوة منها، و الكثف عن مو اطن القوة و الضعف في هــــه العطليـة،

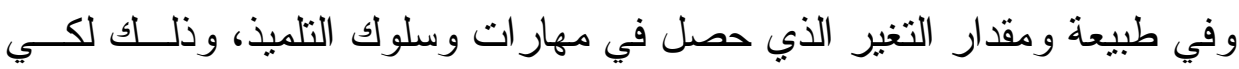

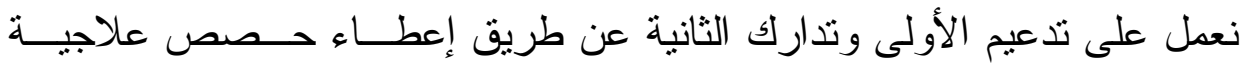

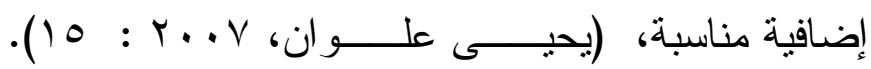

$$
\begin{aligned}
& \text { عوامل التّمية البثريّة }
\end{aligned}
$$

• كي تتحقّق التّمية البشريّة في أبيّ مجتمعِ كان لا بُدّ من تضافر العديد مسن

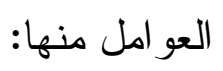

• الاستقر ار السيّاسيّ و انتشار الحريّة و الديمقر اطيّة، ووجود الحكومات التـي

$$
\text { تتعهد بتتفيذ التّمية في مجتمعاتها. }
$$

• معرفة الحققيّة للقُدرات البشريّة وخاصيّة الثَّباب و الطّاقة الهائلة التي يتحلّون بها وكيفيّة استغلالها بما يعود بالنّفع على الفرد و المجتمع.

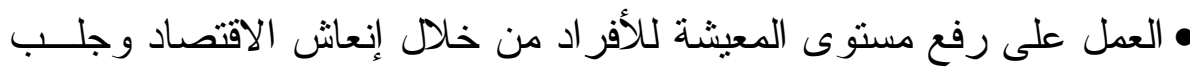
الاستثمار ات الخارجيّة وتتشيط عجلة الصنّاعة و الأعمال الحرفيّة و المهنيّة. • اعتماد أساليب إداريّة تقوم على التخطيط وحُسن الإدارة و التقييم المستمرّ. • العمل بشكلٍ منتظٍٍٍ عن طريق معرفة الاختصاصات المطلوبة وتقسيم العمل

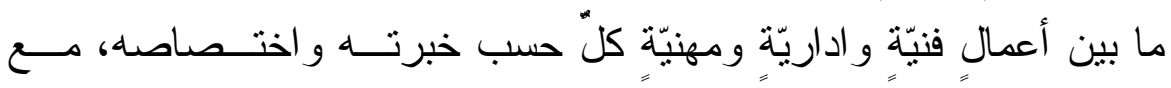
استخدام وسائل التّنية الحديثة و التكنولوجيّة.

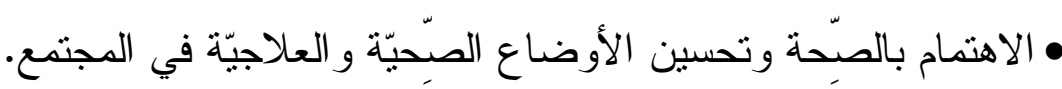
•تطوير التّعليم و أساليبه ومدخلاته للحصول على مخرجاتٍ جيدّة.

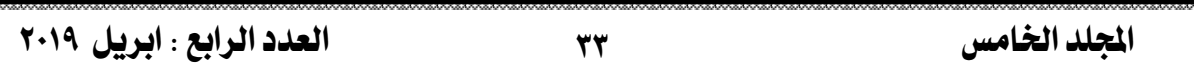


• كسر حاجز الروتين و السعي إلى آفاق جديدة في الحياة خاصيّةً بعد المـرور

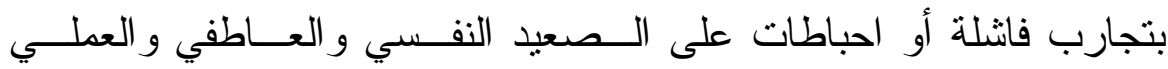

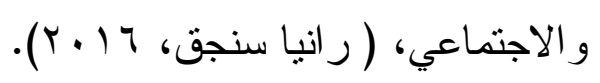

التعليم و التنمية البشرية

التعليم يحتاج إليه البشر ليمكنهم من ممارسة حياتهم و أدوارهم الأساســية

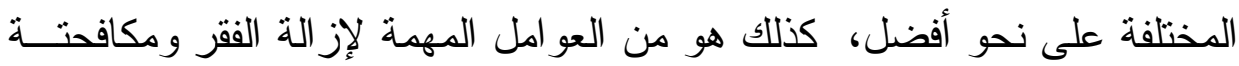

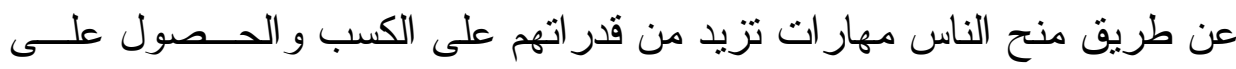

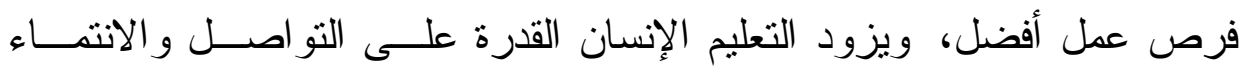

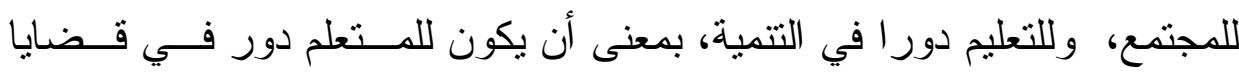

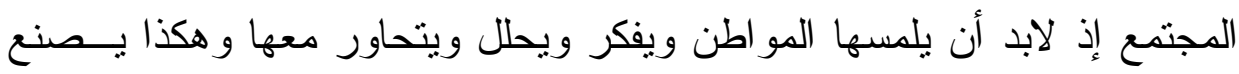

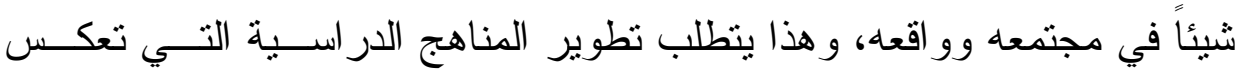
المو اضيع الحياتية و التي يعيشها المو اطن كل يوم (صحة، زر اعة، مياه، صرف صحي، المر أة).

فالتتمية البشرية هي الر افد و المرتكز الأساسي لجميـع جو انــب التتميــة

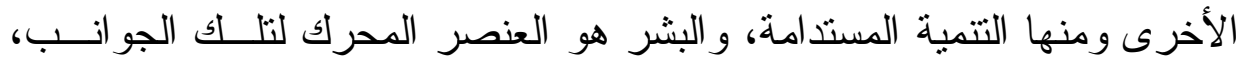

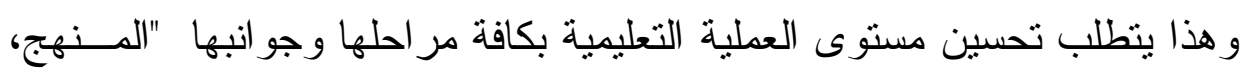

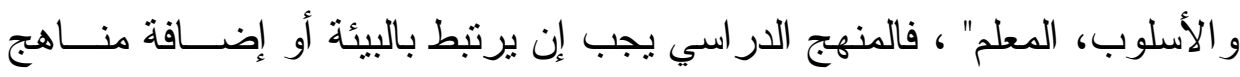
يتعلم الفرد من خلاها كيفية التعامل مع البيئة بجو انبها المختلفة، وان يبتعد المعلم عن إتباع أسلوب الحفظ للمادة و إنما يقوم دائما بتوجيه التلاميذ إلى كيفية استثمار

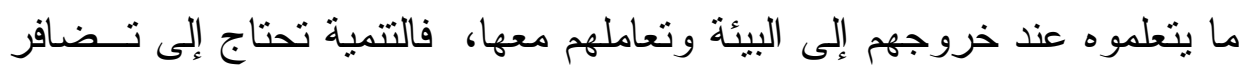


الجهود، و التربويين بيدهم مفاتيح جميع جوانب التتمية لأنهم هم المصدر الممول

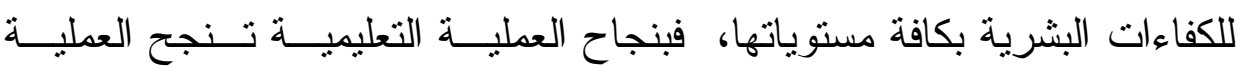

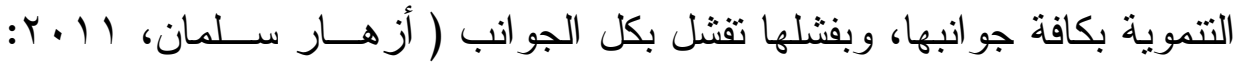

\section{تكنولوجيا المعلومات و أثرها فى التنمية البشرية}

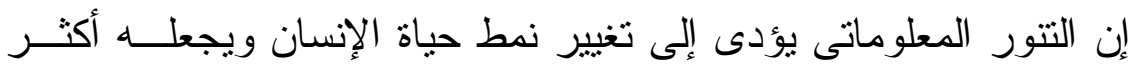
قدرة على مو اجهة تحديات العصر ، و التى يمكن تحديد أهمها فى الآتى:

1- التحدى الثقافى: يقصد به مو اجهة عمليات الغزو الثقـافى و الاستـشر اق الجديد الذى يستخدم الوسائل المعلومانية الحديثة لتغيير تر اثثا. ץ- التحدى التربوى: هو تهيئة مدارسنا وجامعاتتا على إعداد الإنسان المبدع

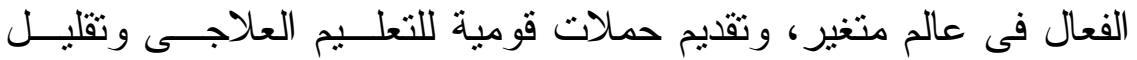
الهادر البشرى الذى تفرزه نظم تعليمنا الرسمية، و الربط بــين النظريـــة و التطبيق، وتقديم خدمات تعليمية أفضل من خلال اســتخدام الكمبيـــتر ونظم المعلومات

r- التحدى العلمى و التكنولوجى: يقصد به القــدرة علــى اســتثمار العقــول العربية بفاعلية فى إطار سياسات علمية فى صورة نثاط مؤسسي منـتـج، مع وقف نزيف العقول المهاجرة"على وجه الخصوص"، وترشيد عمليات توطين التكنولوجيا فى بيئتنا العربية.

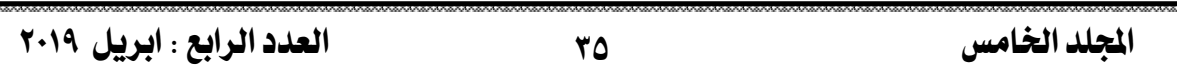


أهداف التنمية البشريّة

تسعى النتمية البشريّة إلى تحقيق جُملةٍ من الأهداف المهمة، وهي:

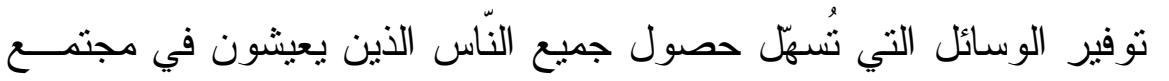

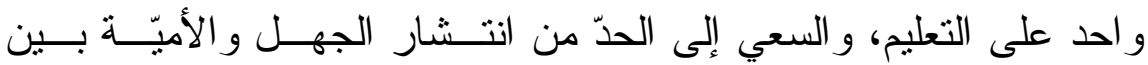

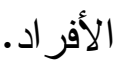

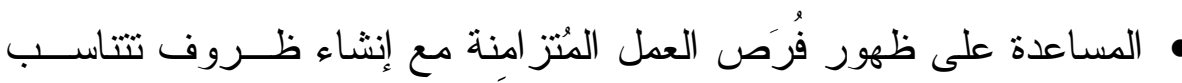

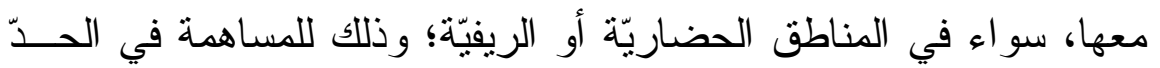

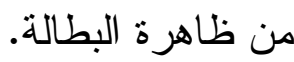

• السعي إلى تطوير مستويات الرعاية الصحيّة، وتحديداً المُتعلقة بالأطفــال الذين نقل "أعمار هم عن خمسة عشر عاماً. • المشاركة في بناء المساكن المناسبة للأفر اد من أصحاب الدخول المحدودة.

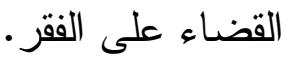

• السعي إلى رفع دخول النّاس؛ لتحسين مستوى معيشتهم.

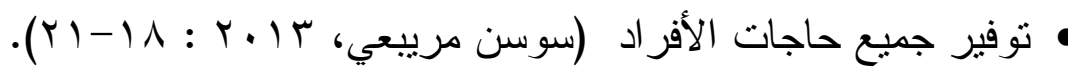

شروط التنمية البشرية

قد أثنار المختصون في علم التتمية البشرية إلى أن للتنمية البشرية العديد

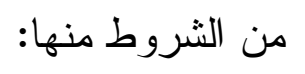

* شروط إداريه كارتفاع المهار ات الفنية و الإدارية، وتطور أسـاليب الإدارة، و اعتماد أسلوب التخطيط، و واستخدام التقنية وتوطينها، وشــروط ســـانية التهانية

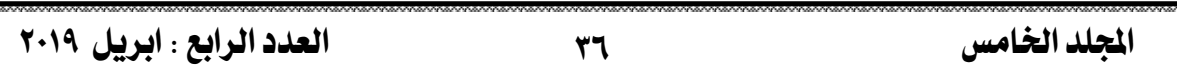


كالاستغلال الأمتل للموارد البشرية، وارتفاع مستوي المعيشة، وشــروط صحية كتحسن مستوي الرعاية الصحية، وشروط اجتماعية كنـــو ثقافـــة العمل و الإنجاز، وتغير الدفاهيم المقترنة ببعض المهن والحرف، ومرونة العنة البناء الاجتماعي و المساو اة الاجتماعية، وشروط نفـــية كتهيئـــة المنــــاخ النفسي العام و التشجيع على التنمية. التنمية البشرية وتنمية الذات

•تتميه الذات: ويشمل مفهوم التتمية البشرية عديد مـن المجــالات ، ومنهـــا

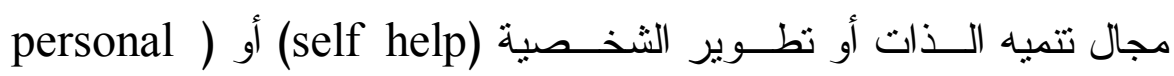

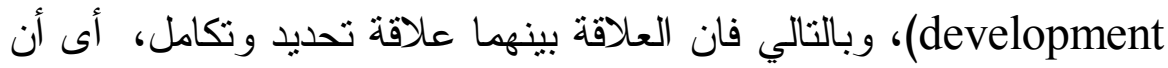

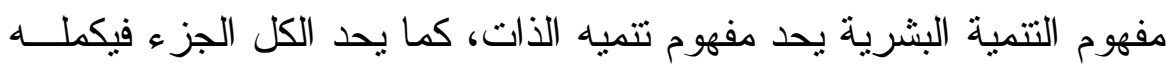

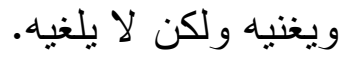

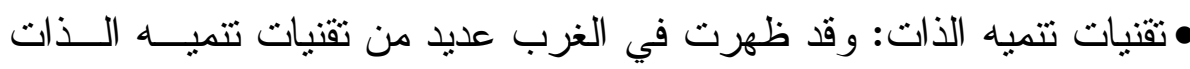
منها: البرمجة اللغويـة العـصبية (Neuro-linguistic programming)

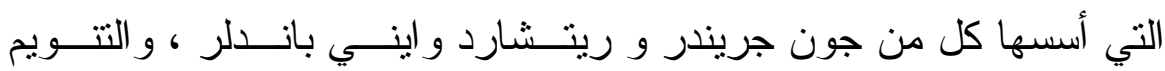

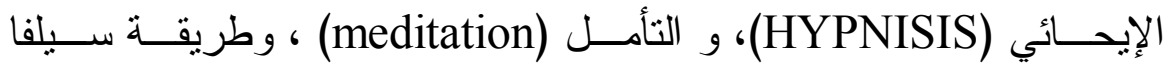

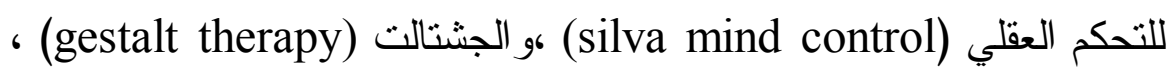
و الفكرة الأساسية التي تستتد إليها هذه التقنيات هي :أن تغيير العالم يبدأ من

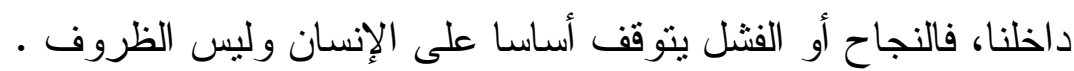
• تتميه الذات بين الرفض و القبول: ورغم شيوع مفهوم تتميه الذات و أســاليبه المختلفة في الغرب ، إلا انه تعرض للانتقاد من بعض الباحثين باعتبار انه ليس علما بالمعنى الدقيق للكلمة، نتيجة لافتقاره للموضوعية، و الو اقع مسن لـن لئن

المجلد الخامس


الأمر أن مفهوم تتميه الذات بأساليبه المختلفة هو فن(تكنيك) أكثر منه علم ،

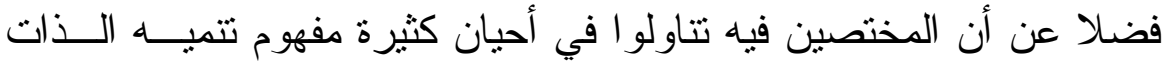
وتظوير الثخصية من منظور شخصي يستتد إلى الخبرة الذاتية، وهنا نشير إلى انه رغم صحة الأصول الفكرية لمفهوم تتميه الذات ممثله في قاعدة أن تغيير العالم يبدأ من الذات، إلا أن العديد من المختصين الغربيين في التتمية

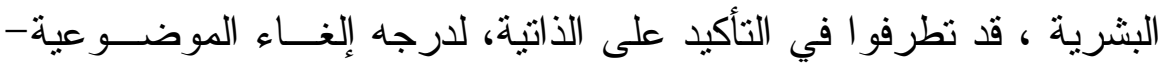

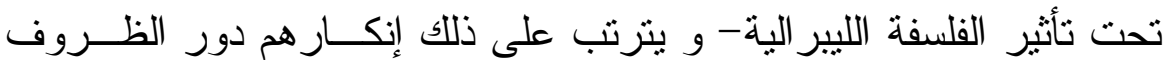
كعامل معوق أو مساعد في حركه التطور الاجتماعي( صبري محمد خليل: $\cdot(r \cdot) 1$

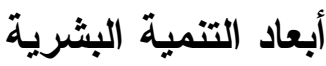

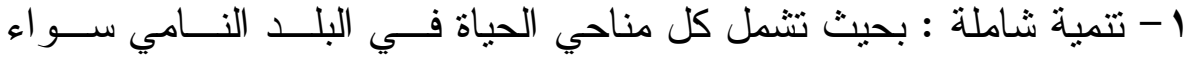

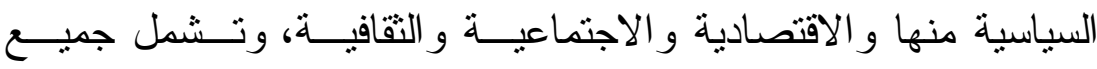
المؤسسات الحكومية و الخاصة و الأهلية الموجودة فيه، وتـشمل كــللك

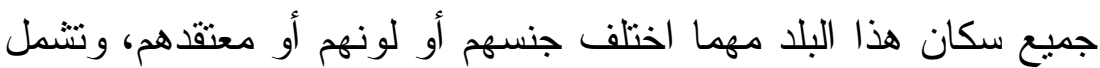

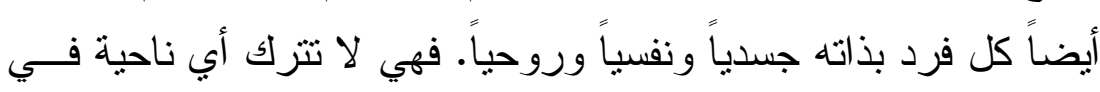
هذا البلد إلا وتعمل على تطوير ها وتحسينها. r - تتمية متكاملة : تهتم بجميع الأفر اد و الجماعات و التجمعات و المجــالات المختلفة و المؤسسات الحكومية و الأهلية من ناحية تفاعلها مع بعـضهها، بحيث تكون غير متتافرة و لا متتاقضة، ولا يمنع نمو أحدها نمو الآخر

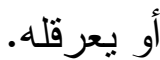


r - تتمية مستدامة : تسعى دائماً للأفضل، وتكون قابلة للاستمر ار من وجهة

نظر اقتصادية و اجتماعية وسياسية وبيئية وثقافيــة. ومفهـــوم التنميــة البشرية المستدامة يعتبر الإنسان فاعل أساسي في عملية التتمية ولــيس مجرد مستفيد من منتجات التتمية دون مشاركة نشيطة فاعلة (رغــداء

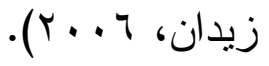
معوقات التتمية البشرية

توجد مجموعة من المشكلات التي تعيق تطــورّ التتميــة البـشريّة فـي المجتمعات و الأٌّول، وتُلخّص وفُّاً للنقاط الآتية: - غياب عنصر التدريب وتطوير المهار ات في المنظمات.

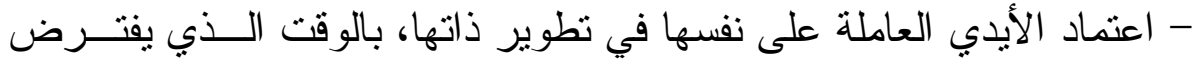
على صاحب العمل أن بعمل على تدريب وتوجيه جهود أفر اده. - الافتقار لذوي الاختصاص و الكفاءة في الموارد البشرية. - غياب الوعي المؤسسي و الفردي بمدى أهمية التتمية البشرية، و إهمالها. - تدني مستويات الميز انية في مشروعات التتمية البشرية؛ ما يجعـلـ منهــا عاجزة عن التطور و النمو .

- عدم مشاركة أرباب العمل الخاص بدور هم المتوقع في التتمية البشرية. - غياب التتسيق بين نتظيمات المجتمع المدني للتأثنر بمـشروعات التنميـــة

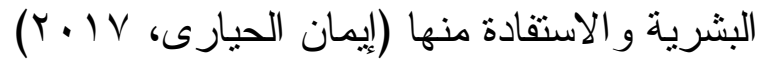


الار اسات السابقة

دراسات تتعلق بالمحور الأول: استر اتيجيات التعلم النشط:

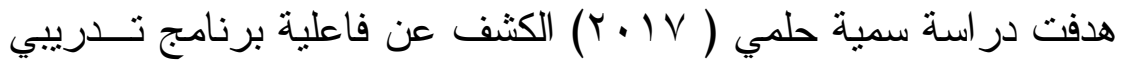
مقتر ح قائم على استر اتيجيات التعلم النشط في تتمية مهار ات التدريس الإبـــاعي

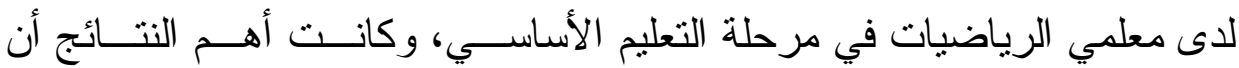
البرنامج المقترح يتتتع بالفاعلية المقبولة في اكتساب التدريس الإبداعي ومهار اته

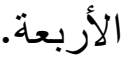

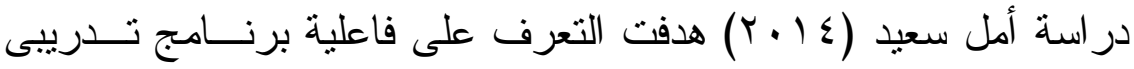

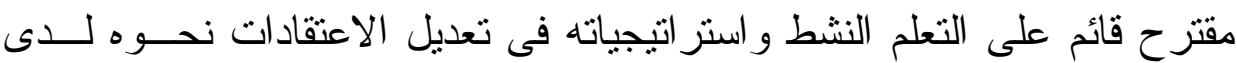
معلمات الجغر افيا، وتوصل البحث إلى وجود فروق ذات دلالة احسصائية بــين

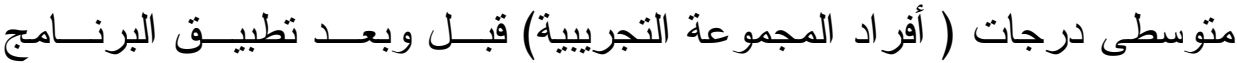
التدريبى لصالح التطبيق البعدى، مما يشير إلى أن البرنامج كان له نأثثر فعـال

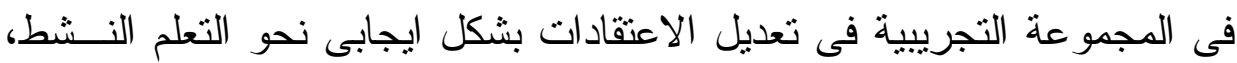

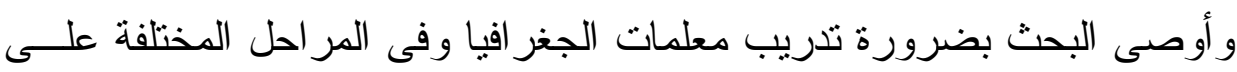
استخدام استر اتيجيات التعلم النشط مع طالباتهن. هدفت در اسة منى مصطفى ( r ب r) إلى فاعليــة البرنــامج التــريبى

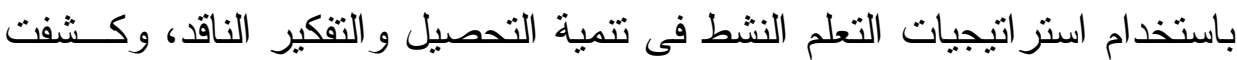

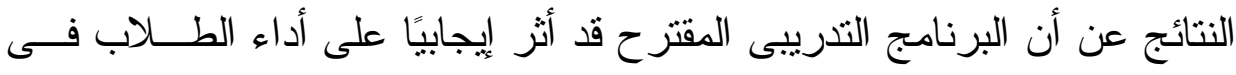

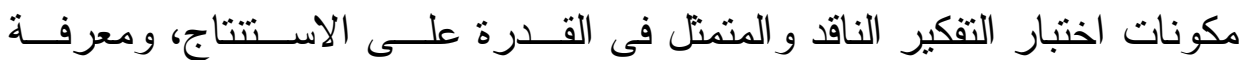

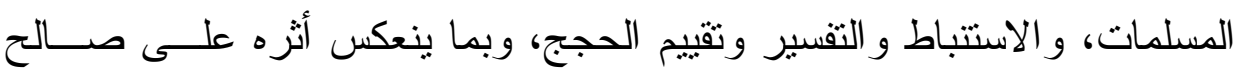
العطلية التعليمية وتحقيق أهدافها المنشودة. 


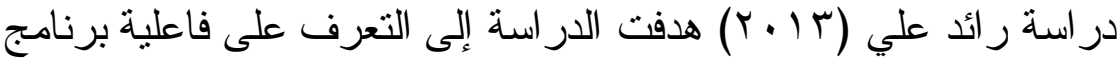

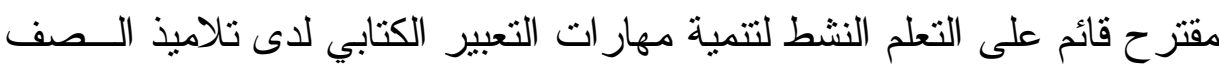

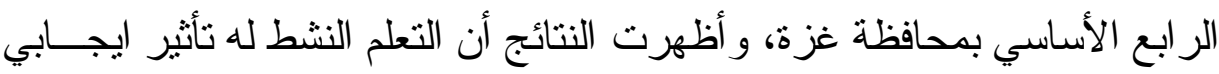

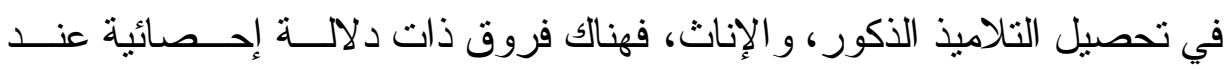

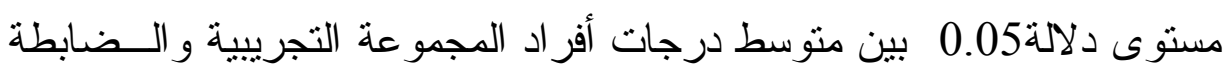
وأن هذه الفروق كانت لصالح المجموعة التجريبية.

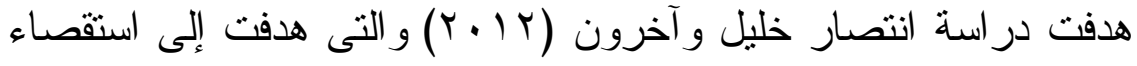

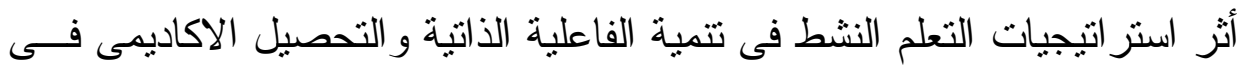
مادة الإرشاد التربوى، وكثفت الدر اسة عن وجود فروق ذات دلالـــة إحـصـائية

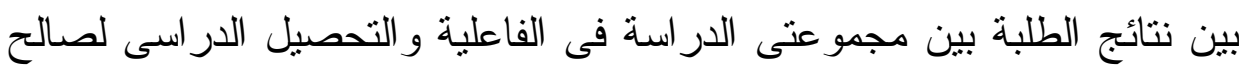

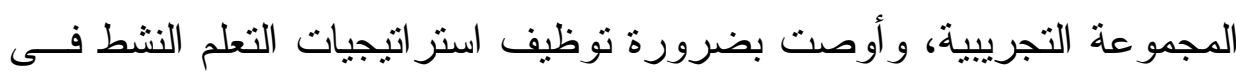

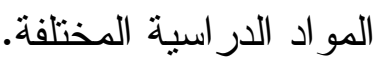

دراسات تتعلق بالمحور الثانى: التنمية البشرية:

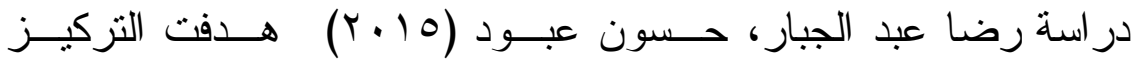

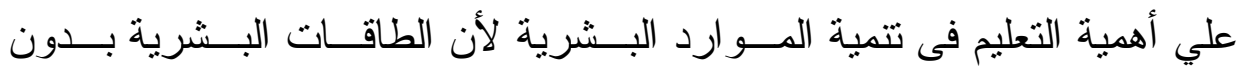

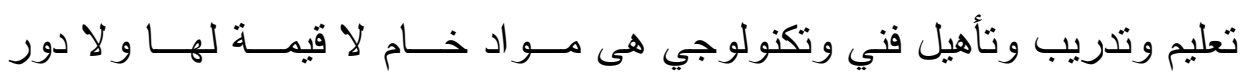

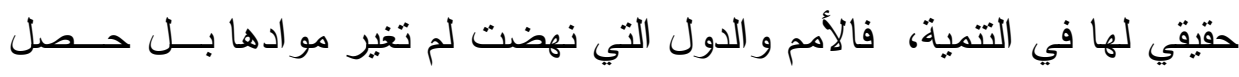

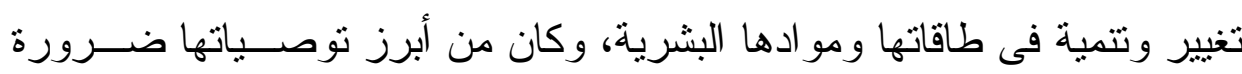

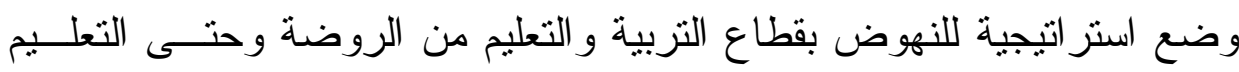

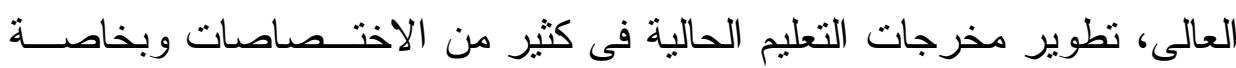

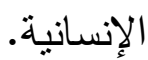




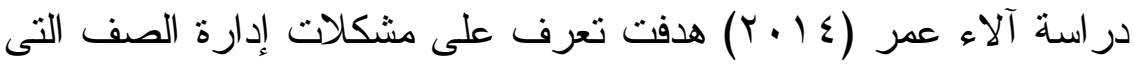

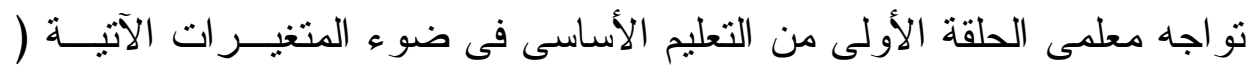

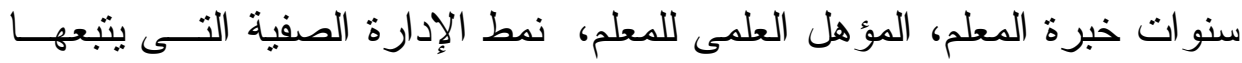

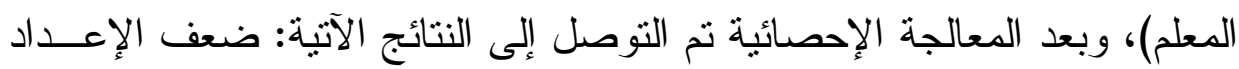

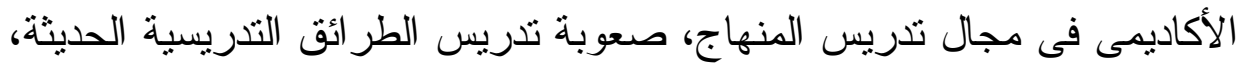

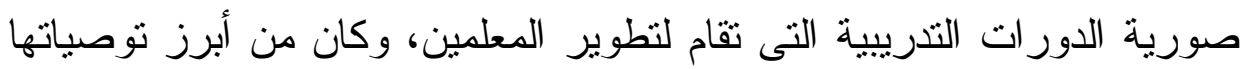
ضرورة إجر اء محاضر ات نو عية للمعلمين عن كل جديد فى الإدارة الصفية.

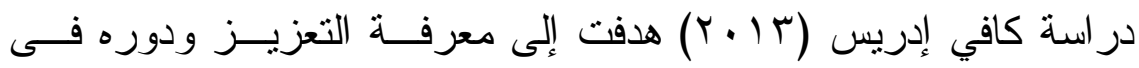

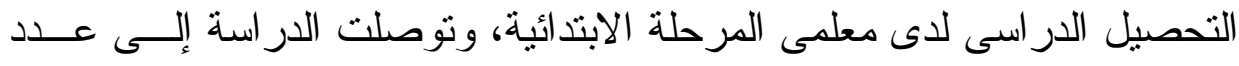

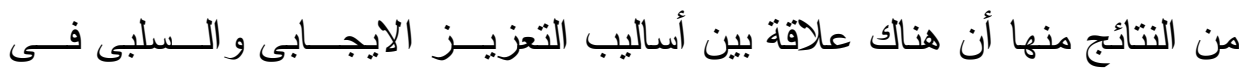

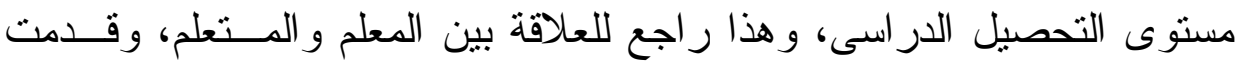

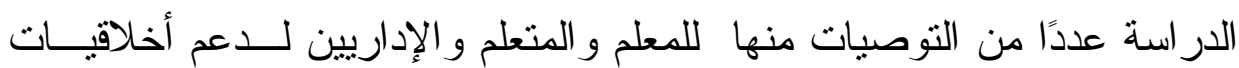

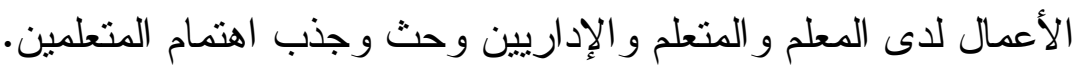

در اسة (2013) مدفت التعرف على فعالية التـدريب

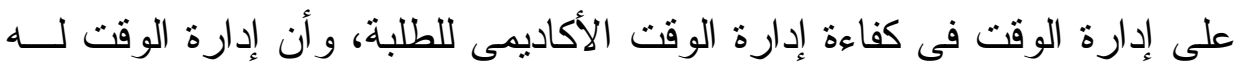
تأثير إيجابى على الأداء الاكاديمى للطلبة. در اسة (2012) Menon هدفت الدر اسة تعرف على مسشـاكل المعلمـين

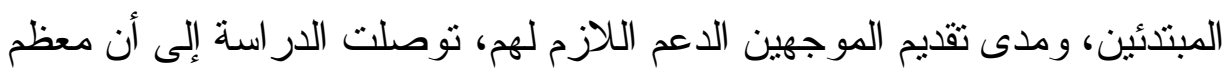

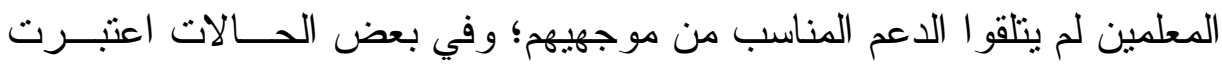

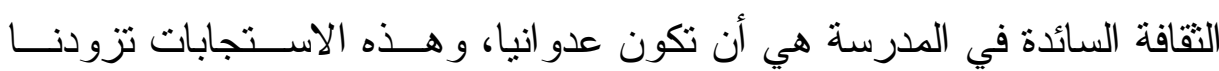


بمقترحات للتغلب على هذه المشكلات ونتير إلى الحاجة للمزيد من دعم الموجهين و المزيد من التو اصل و الانفتاح في المناخ التنظيمي.

من خلال ما تم عرضده من در اسات سابقة، فقد ألقت الباحثة الضوء على أهمية مهارة الاتصال و إدارة الصف و التعزيز و القياس و التقويم بالنسبة للمعلمة

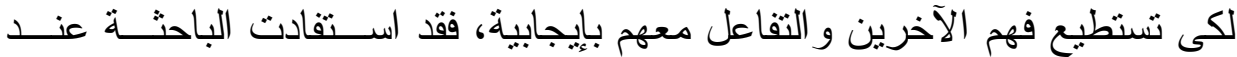
تصميم البرنامج التدرييى و استعانت بعدة أنشطة لتوضيح العناصر الفرعية لكـلـ

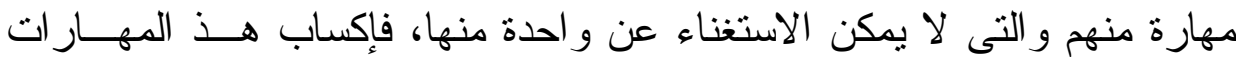
للمعلمة كم تبين مما سبق ضرورى لنجاح العملية التعليمية، وخاصـــة مرحلــة رياض الأطفال، لذلك فقد حرصت الباحثة أثتـــاء تــصميمها للبرنـــامج إثرائـــه بالأنشطة و المو اقف المعدة مسبقًا .

$$
\text { أولًا: إجر اعات البحث }
$$

استخدمت الباحثة التصميم التجريبى ذو المجموعة التجريبيـة الواحـــة، حيث تمت معالجة المتغير المستقل (برنامج القائم علـىى اســتر اتيجيات الــتعلم النشط) ورصد أثزه على المتغير التابع ( بعض مهار ات التنمية البشرية). ب - مينة الار اسة

تتمثل عينة البحث الحالى فى عينة قو امها ( •r) معلمة فى مرحلة رياض

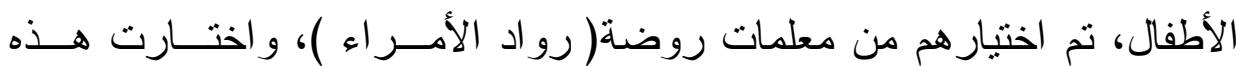
الروضة لوقو عها فى منطقة منوسطة اجتماعيًا، يعيشون حياة اجتماعية مستقرة. 
1 - إعداد بطاقة تقدير مهارات التنمية البشرية ( إعداد الباحثة)

ظهرت الحاجة لدى الباحثة لإعداد بطاقة تقدير مهارات التتمية البشرية ؛

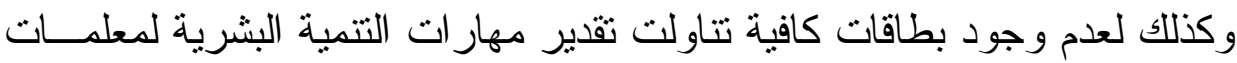

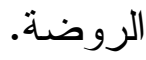

• خطو ات إعداد بطاقة تقدير مهار ات النتمية البشرية لمعلمات الروضة فـى

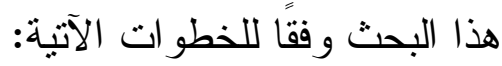
أ- تحديد الهدف من بطاقة التقدير:

استهدف إعداد هذا البطاقة، لتقدير مستوى اكتـساب مهــار ات التتميــة

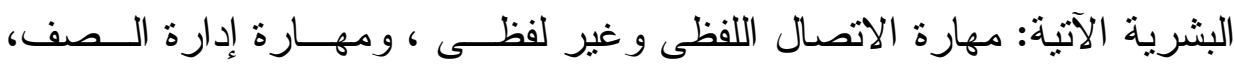

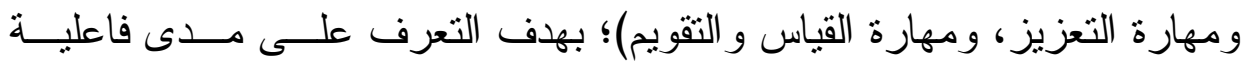
برنامج تدريبى قائم على استر اتيجيات التعلم النشط. ب - تم إعداد بطاقة تقدير مهارات التنمية البشرية لمعلمات الروضة بالإفادة

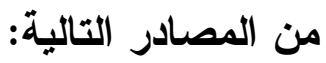

- الاطلاع على الاختبارات الخاصة لقياس مهار ات التتمية البشرية ، ومنها مهارة الاتصـال اللفظى وغير لفظى ، ومهــارة إدارة الــصف، ومهــارة التعزيز، ومهارة القياس و التقويم. - الإطلاع على الدراسات و البحوث السابقة والأطر النظرية المتعلقة بقياس مهار ات التتمية البشرية لمعلمات الروضة. 
ج - إعداد بطاقة التقدير فى صورتها المبائية: تم إعداد بطاقة التقدير فى صورتها المبئية وفق الخطوات الآتية: 1- تحديد وحدات البطاقة: تم إعداد قائمة تتضمن مجموعــة مــن مهـار ات التتمية البشرية لمعلمات الروضة ، وعرضت على المحكــين لاختبـار أربعة مهار ات السابقة الذكر.

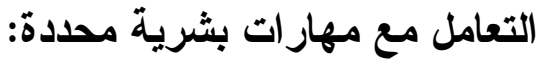

اقتصر البحث على محاولة تتمية (مهارة الاتصـال اللفظى وغير لفظـى ،

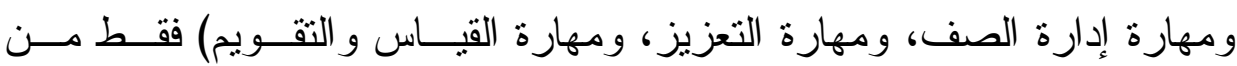
مهار ات التنمية البشرية لمعلمات الروضة وهى من خلال استخدام برنامج قــائم

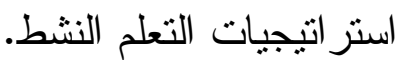

أعدت الباحثة قائمة بمهار ات التتميـة البـشرية لمعلهـات الروضــة ،

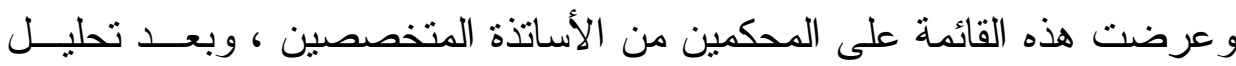
استجاباتهم اختارت الباحثة المهارات التالية (مهارة الاتصال اللفظى وغير لفظى التهى ، ومهارة إدارة الصف، ومهارة التعزيز، ومهارة القياس و النقويم)؛ حيث حازت التهال

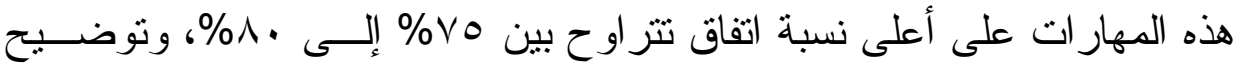

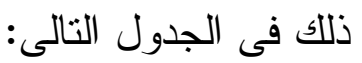

و هذه المهارات تحتاجها معلمات رياض الأطفال ، وهو ما أتنتته الأدبيات المعينة بهذا الهجال وما أثنارت إليه البحوث و الدراسات السابقة.

وروعى عند صياغة مفردات البطاقــة دقتهــا، حتــى يتحقـق التتاســق و التجانس بين البدائل من حيث الطول. ( ملحق رقم اليطه ) 
وقد تكونت البطاقة من ( ع rعبارة ) توزعت على أربعة مهار ات كالتالى:

أ - مهارة الاتصال اللفظى وغير لفظى تتكون من (؟) عبار ات .

ب- مهارة إدارة الصف تتكون من (آ) عبار ات.

ج- مهارة التعزيز تتكون من (؟) عبار ات

د - مهارة القياس و التقويم تتكون من (؟) عبار ات

• كتابة التعليمات المصاحبة لنطبيق المقياس.

جـ - عرض بطاقة التقدير فى الصورة المبائية على السادة المحكمين:

بعد الانتهاء من بناء البطاقة فى صورتها الأولية تم عرضها على الـسادة

المحكمين المتخصصين فى مجالات نربية الطفل، وعلم النفس التربوى، ومناهج

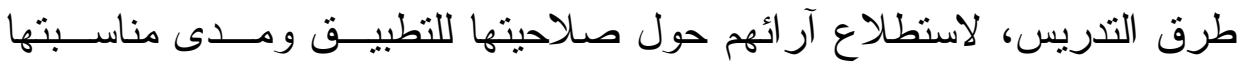
ل معلمة الروضة.

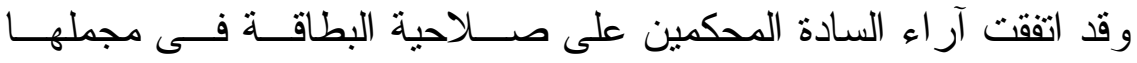

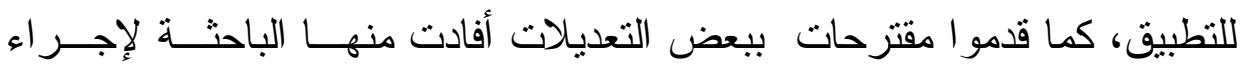
التعديلات، وبالانتهاء من إجر اء تلك التعديلات أصبحت البطاقة جاهزةً لتجربتها على العينة الاستطلاعية. هـ - التجربة الاستطلاعية لبطاقة التقدير: هدفت هذه التجربة إلى تحديد زمن البطاقة، وحساب الثثابت الإحـصائية

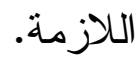


- تقاير الارجات وتصحيح البطاقة:

خصصت درجة صفر للإجابة الخاطئة عن كل عبــارة مــن العبـارات

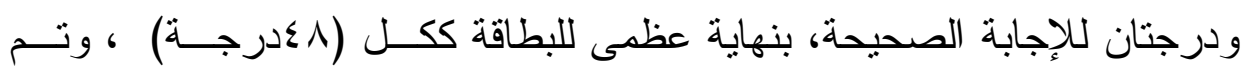

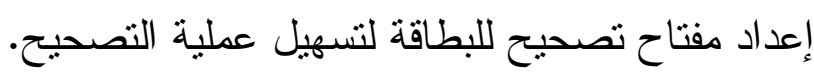

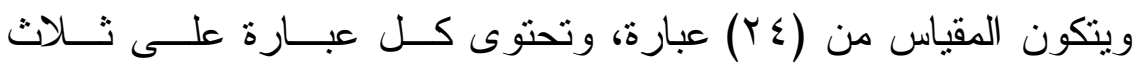

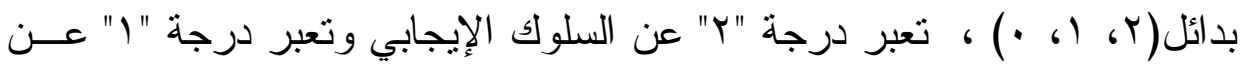

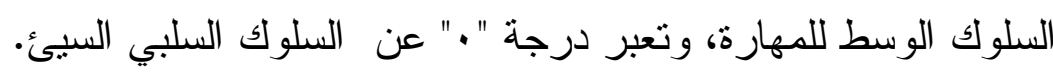

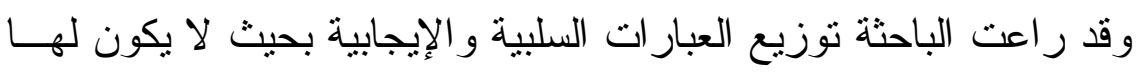

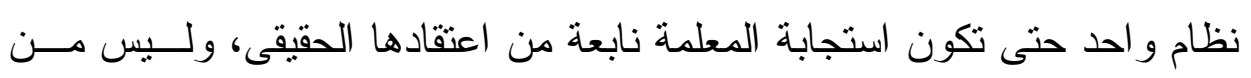
استحسانها للموقف.

( ) حساب المعاملات الإحصائية لبطاقة التقدير.

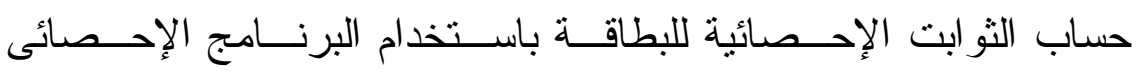
(SPSS)، وتمتل ذلك فى حساب صدق البطاقة وثباتها، وذللك كما يأتى: أ - مساب ثبات بطاقة التقدير:

تم حساب ثبات البطاقة باستخدام طريقة إعــادة الاختبـار علــى عينــة

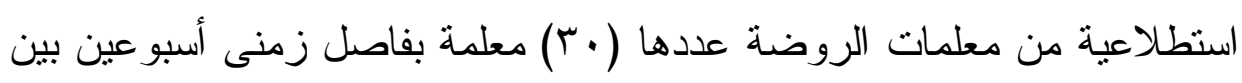

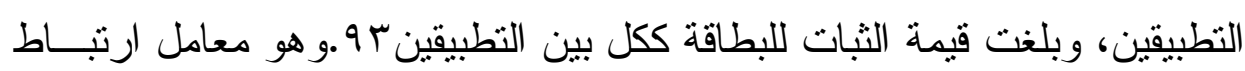
قوى يدل على ثبات البطاقة.

المجلد الخامس




\section{ب - حساب صدق البطاقة:}

تم استخدام عدة أساليب للتحقق من صدق البطاقة وهى كالتالى: 1 - - الصدق الظاهرى:

حيث قامت الباحثة بعرض البطاقة بعد صــياغته علـى مجموعـــة مــن

المحكمين - كما سبق توضيحه - ولقد أجمع المحكمين على صلاحية البطاقــة للوفاء بالغرض المنوط به وتر اوحت نسب الاتفاق على عبار ات ابعــاد بطاقــة التقديرما بين 01 و . . ( \% و أنه على درجة عالية من الصدق. r - بدق الإتساق الاخلى: تم حساب الارتباط للمفردات بالدرجة الكلية باستخدام طريقـة الاتـساق

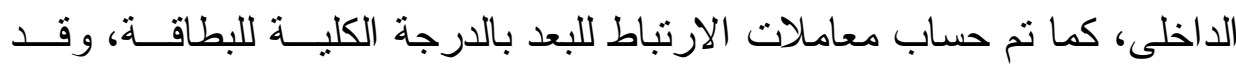
جاءت قيم معاملات الارنباط لمعظم عبار ات المقياس دالة - فى مجملها - عنـــ مستوى دلالة (0.,)، و هذا يعنى تحقق درجة التماسك الداخلى لهــذه العبــار ات لمؤشر الصدق، وذلك كما هو موضتح بالجدول رقم (r). و - الصورة النهائية للبطاقة: بعد التأكد من كفاءة البطاقة أصبحت الصورة النهائية للبطاقة مكونة مــن (Y ) عبارة موزعة على أربعة مهار ات فرعية ونتمنل فى (مهــارة الاتـصال اللفظى وغير لفظى ، ومهارة إدارة الصف، ومهارة التعزيز، ومهــارة القيــاس

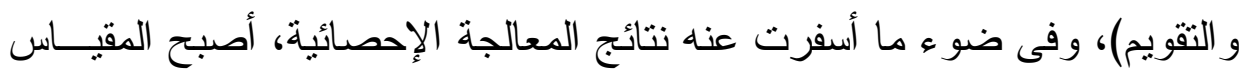
صالحًا للتطبيق فى تجربة البحث الأساسية (ملحق (). 
Y - إعداد برنامج قائم على استراتيجيات التعلم النثط ( إعداد الباحثة).

أويًا: خطوات بناء برنامج قائم على استراتيجيات التعلم النثط

$$
1 \text { - الفلسفة القائم عليها البرنامج. }
$$

تعتمد فلسفة البرنامج على أحد أهم مسلمات التربية السيكولوجية وهى أن الإنسان قادر على تحقيق النمو الذانى وذللك فى ضو قابلية المخ للنمو والتعديل، كما تستتد فلسفة بناء البرنامج أيضًا على إسهامات النظريات الفلسفية فى تربيـــة

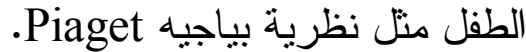
افتقار المعلمين و المعلمات إلــى توظيــف اســتر اتيجيات الــتعلم النـشط

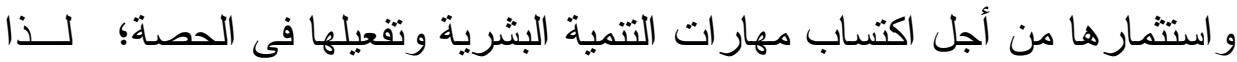

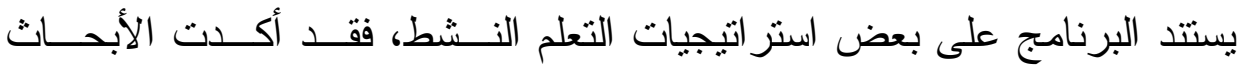

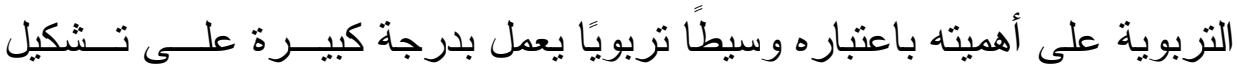
شخصية الطفل بأبعادها المختلفة.

$$
\text { أ - الهدف - تحديد أهداف البرنامج و التى تتمثل فى: }
$$

يعد تحديد أهداف البرنامج بدقة ووضوح من أهم و أولى الخطوات العامة

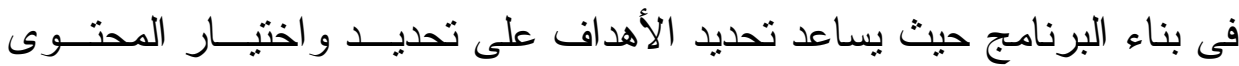
العلمى، و عليه فإن البرنامج الحالى يهدف إلى تتمية بعـضـ مهــار ات التتميــة البشرية المرتبطة بمهارة (مهارة الاتصال اللفظى وغير لفظى ، ومهـارة إدارة

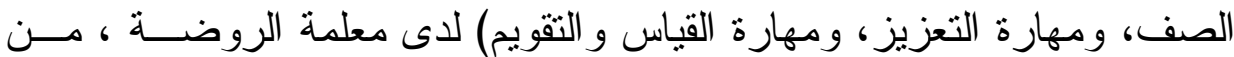
خلال بعض الأنشطة المختلفة. 


\section{ب - الأهداف الخاصة:}

وقد راعت الباحثة أن تكون الأهداف محددة وقابلة للقياس ويأتى تحديــد

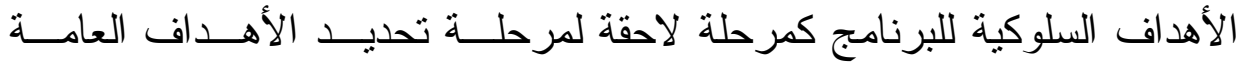

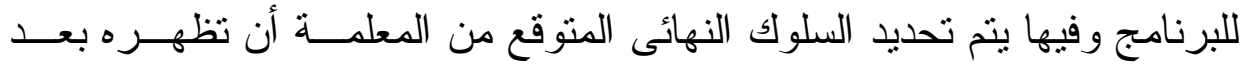
انتهاء عملية التعلم وسيتم تتاول الأهداف السلوكية لكل نشاط من أنشطة البرنامج

على حدة عند عرضها لاحقًا ملحق (Y).

$$
\text { r - تحديد المحتوى العلمى للبرنامـج: }
$$

يتضمن البرنامج مجموعة من الأنشطة المختلفة التى تتــــاول تطبيقاتهـــا

بعض مهار ات التتمية البشرية، حيث يتتاول المحتوى جميـع جو انــب الخبــرة المتوقع من المعلمات اكتسابها بعد التدريب على البرنامج

تم اختيار محتوى البرنامج طبقًا للأهداف المــر اد تحقيقهــا، وتـــن المحتوى مجموعة من الأنشطة، وقد رُوعى:

-تتظيم الموقف بحيث يتضمن المتطلبات الأساسية اللازمة لتكــوين المهــارة المطلوبة لدى المعلمات.

-شمولية محتوى البرنامج على جميع جو انب الخبرة و المهارة المطلوب تتميتها لدى المعلمات مهنياً و أكاديمياً.

- ملائمة محتوى البرنامج للأهداف الموضو عة و القدرة على تحقيقهــا لــدى المعلمات.

- مر اعاة الفروق الفردية بين المعلمين. - القابلية للتقويم المستمر بأنو اعه. 


$$
\text { צ - الوسائل والأدوات المستخدمة فى البرنامج: }
$$

استخدمت الباحثة مجموعة من الوســائل التعليميــة المـساعدة و الأدوات

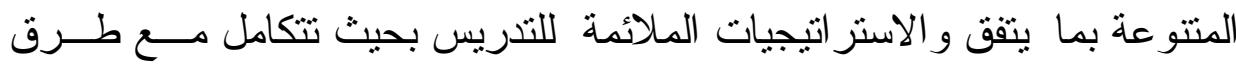
تقديم البرنامج لتحقيق أهدافه، وقد تمنلت الوسائل في التالي:

$$
\text { -جهاز العرض المرئي (LCD) لعرض النشاطات على السبورة. }
$$

- سبورة بيضاء ثابتة.

$$
\text { - جهاز حاسوب محمول. }
$$

ه- الاستر اتيجيات المستخدمة فى البرنامج:

تضمن البرنامج استخدام بعض استر اتيجيات التعلم النشط:

(استر اتيجية التعلم التعاونى - استرانيجية لعـب الأدوار - اســتراتيجية

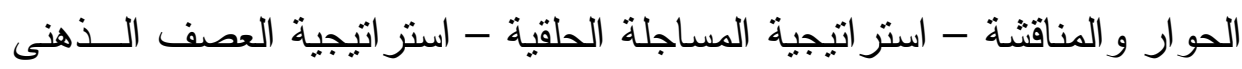
- استر اتيجية القصص - استر اتيجية المقابلة ثلاثية الخطوات).

$$
\text { צ- أساليب التقويم }
$$

استخدم فى البرنامج الحالى أساليب التقويم التالية:

التقويم القبلى: ويتضمن إجر اءات تطبيق مقياس مهار ات التتمية البشرية

$$
\text { على معلمات رياض الأطفال ( إعداد الباحثة). }
$$

التقويم المصاحب: وهو تقويم المعلمة بشكل متلازم ومستمر منــــ بدايـــة

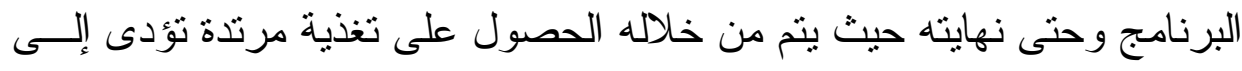

المجلد الخامس


التعديل المستمر للبرنامج، ويتم ذلك بشكل يومى أثناء أو بعد تقديم النشاط مسن خلال تطبيقات نربوية موجهة للمعلمة.

التقويم البعدى: وهو الذى سيتضمن إجراءات تطبيق مقيــاس مهـارات

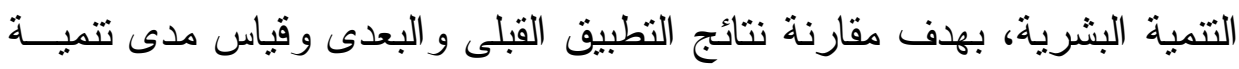

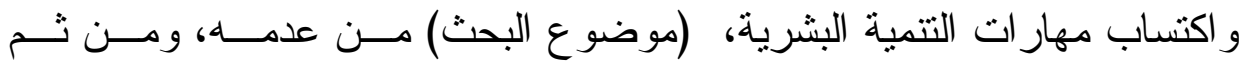
التعرف على مدى فاعلية البرنامج المقتر ح. - ع - V - V

تم عرض البرنامج فى صورته المبدئية على مجموعة مسن المحكــين

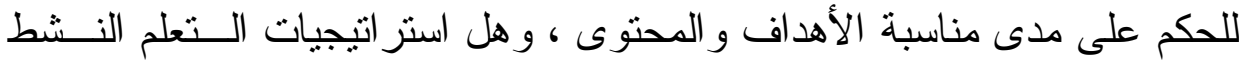

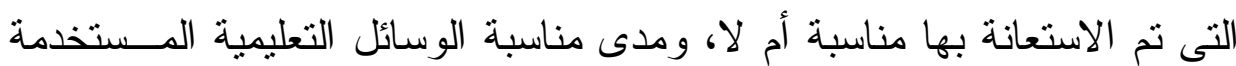

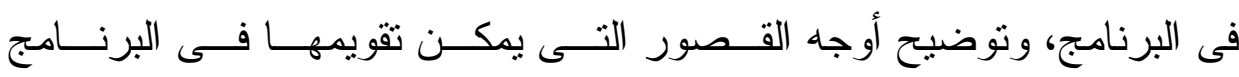
وتعديلها.

وبالإضافة إلى ما سبق طلب من السادة المحكمين إبداء آر ائهم بالتعديل أو

$$
\begin{aligned}
& \text { الحذف أو الإضافة على كل بنود البرنامج . } \\
& \text { وتتلخص أهم النتائج فيما يأتى: }
\end{aligned}
$$

- اتفق المحكمين على مناسبة الأهداف العامة للبرنامج.

- أجمع المحكمين على ملائمة محتوى البرنامج للمعلمة.

- أجمع المحكمين على مناسبة المو اد و الوسائل التعليمية فى البرنامج. - أجمع المحكمين على أن البرنامج صالح للتطبيق بعد إجــر اء التعـديلات

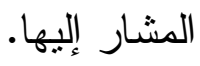


فى هذه الخطوة قامت الباحثة بتتفيــذ أنـشطة البرنـــامج مــع معلمــات المجموعة التجريبية بعد إجر اء قياس قبلى لقياس بعض مهار ات التتمية البشرية،

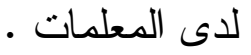

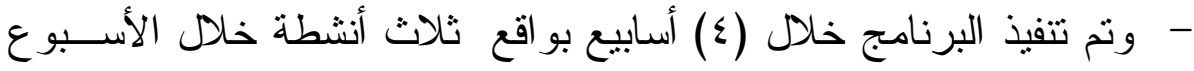

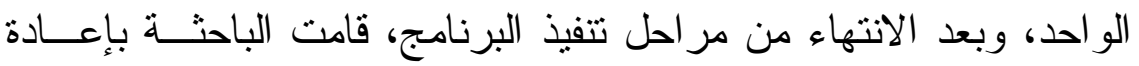
تطبيق بطاقة تقديرمهار ات التتمية البشرية، كتطبيق بعدى لمعرفة دلالـــة فاعلية البرنامج مع معلمات المجموعة التجريبية (عينة البحث ) فى تتمية

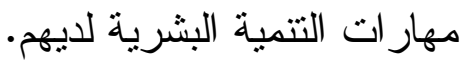
نتائج البحث أولًا: ضبط أدوات البحث أ- الصدق الظاهرى

تم عرض بطاقة الثقدير علـى مجموعــة مــن المحكمـين....، بهـــف

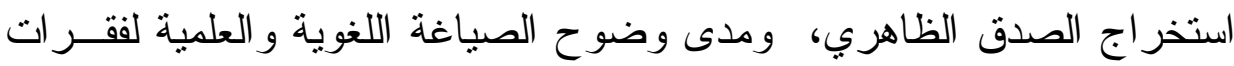

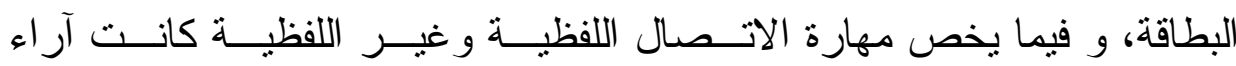

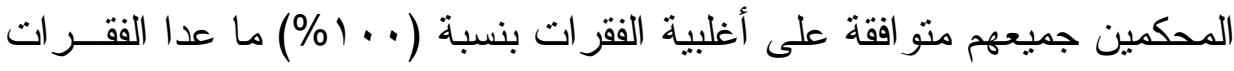

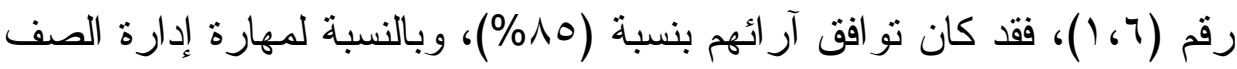

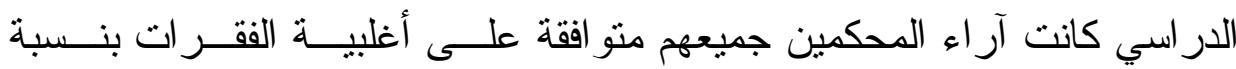

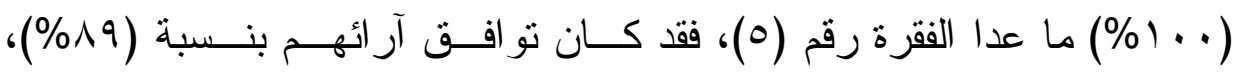

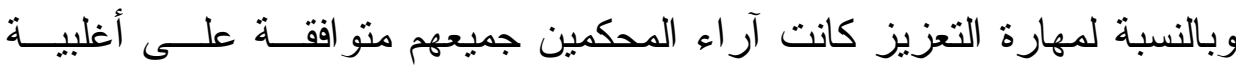

المجلد الخامس


الفقر ات بنسبة ( . . (\%) ما عدا الفقرتين رقم (ء، 0)، فقد كان تو افـق آرائهــ

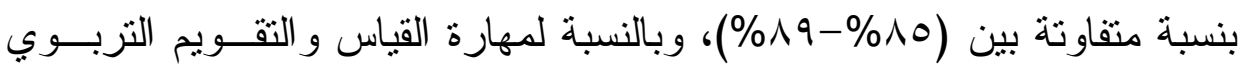
كانت آر اء المحكمين جميعهم منو افقة على أغلبية الفقرات بنسبة ( . . (\%) مـــا عدا الفقرة رقم (ع)، فقد كان تو افق آرائه بنسبة (10\%)، ولذا: تُعتبــر بطاقـــة

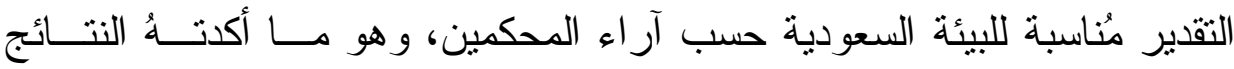
الإحصائية للمر احل التالية من إجر اءات الدر اسة، و الجدول رقـــ (1) يوضــح ذلك.
جدول (1) - - (1)

يبين نسبة الآفاق بين المحكمين على ملانمة الفقر ات ووضوح صياغتها

\begin{tabular}{|c|c|c|c|c|c|c|c|c|c|c|c|}
\hline 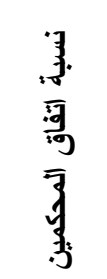 & 滒 & 亏. & 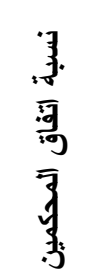 & 滒 & 亏) & 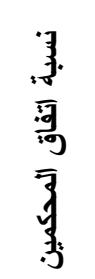 & 滒 & 亏. & 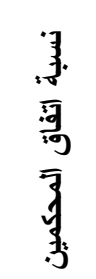 & 滒 & 亏. \\
\hline$\% 100$ & 1 & \multirow{6}{*}{ 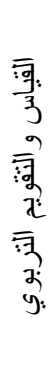 } & $\% 100$ & 1 & \multirow{6}{*}{ 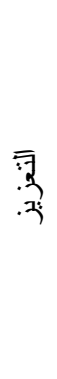 } & $\% 85$ & 1 & \multirow{6}{*}{ 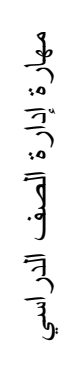 } & $\% 85$ & 1 & \multirow{6}{*}{ 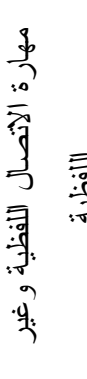 } \\
\hline$\% 100$ & r & & $\% 100$ & r & & $\% 100$ & r & & $\% 100$ & r & \\
\hline$\% 100$ & $r$ & & $\% 100$ & r & & $\% 100$ & $r$ & & $\% 100$ & $r$ & \\
\hline$\% 85$ & $\varepsilon$ & & $\% 89$ & $\varepsilon$ & & $\% 100$ & $\varepsilon$ & & $\% 100$ & $\varepsilon$ & \\
\hline$\% 100$ & 0 & & $\% 85$ & 0 & & $\% 89$ & 0 & & $\% 100$ & 0 & \\
\hline$\% 100$ & 7 & & $\% 89$ & 7 & & $\% 100$ & 7 & & $\% 85$ & 7 & \\
\hline
\end{tabular}


ب - صدق الاتساق الاخلي

جدول رقم (ץ) يوضح الاتساق الاخلي بين العبار ات والمحاور

\begin{tabular}{|c|c|c|c|c|c|c|c|c|c|c|}
\hline 商 & 漓 & $\overline{3}$ & 霄 & 高 & $\overline{3}$ & 露 & 䨐 & $\overline{3}$ & 霄 & 漓 \\
\hline " & 1 & \multirow{6}{*}{ 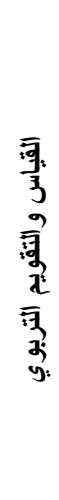 } & סז, יש" & 1 & \multirow{6}{*}{ 哥 } & טר, , & 1 & \multirow{6}{*}{ 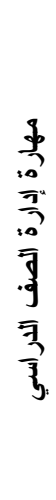 } & *, & 1 \\
\hline זו, , " & r & & $\because, O \mathrm{~V}$ & r & & זו, •." & $r$ & & זו, •*" & r \\
\hline \& & $r$ & & \& ז, , * & $r$ & & *, & $r$ & & $*, v$. & $r$ \\
\hline ז T, & $\varepsilon$ & & \& & \{ & & $*, 01$ & $\varepsilon$ & & " *, & $\varepsilon$ \\
\hline " & 0 & & $\because, 01$ & - & & צ ד, • " & 。 & & זr, •* & 。 \\
\hline * & 7 & & "., , & 7 & & "ד, & 7 & & $* ., 09$ & 4 \\
\hline
\end{tabular}

يتضح من الجدول رقم (Y ) الاتساق الداخلي ويتــر اوح بـين ( •., • -

• V, • ) وهي دالة احصائيا عند مستوى الدلالة ( ه., • ) وهذا يدل على انتماء العبار ات للمحاور وتعتبر استمارة الملاحظة لها صدق مقبــول فــي الأبحـــاث الانسانية.

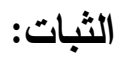

للتحقق من ثبات بطاقة التقدير ، ومستوى صدلاحيتها ونسبة موثوقيتها قــام الباحث بحساب معامل الثبات بطريقة إعادة تطبيق الاختبار test- retest وبلــنغ معامل الارتباط بين التطبيق الأول و الثاني (به, •)، ما يؤكد علــى أن بطاقــة التقدير تتمتع بثبات عال. 
الفرض الأول: توجد فروق دالة احصائيا بين متوسط درجات المعلمـات

في القياسين القبلي و البعدي لـهارة الاتصال اللفظي و غير اللفظي على بطاقـــة التقدير لصالح التطبيق البعدي.

Paired ( للتحقق من صحة هـــا الفـرض تــم اســتخدام اختبــار "ت (Samples Test وذللك للتعرف على الفروق بين متوسطات درجات المعلدــات في القياسين القبلي و البعدي لمهارة الاتصال اللفظي وغير اللفظي والجـدول (r) يوضح ذللك:

جول رقم (r)

نتائج اختبار "T test لعينتين مترابطتين" لدلالة الفروق في القياس القبلي و البعدي للمعلمات لمهارة الاتصال اللفظي وغير اللفظي.

\begin{tabular}{|c|c|c|c|c|c|c|c|}
\hline مستوى & الحرية & T- قيمة Test & الالمعراف & المعياري & الحسابي & العلد & القياس \\
\hline \multirow{2}{*}{$\cdot, \ldots$} & \multirow{2}{*}{ rq } & \multirow{2}{*}{$\begin{array}{c}- \\
r r, 07 .\end{array}$} & גדו, & 1,877 & $r, v$. & r. & القياس القبلي \\
\hline & & & . r rq & 1, ror & 9, or & $r$. & القياس البعدي \\
\hline
\end{tabular}

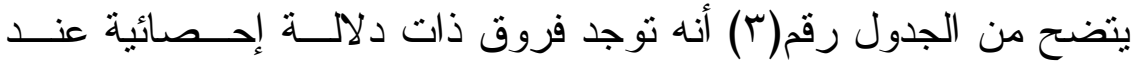

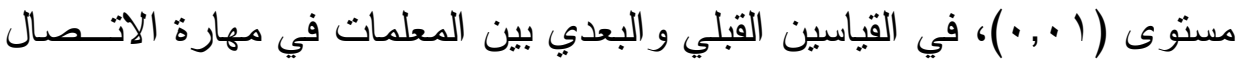

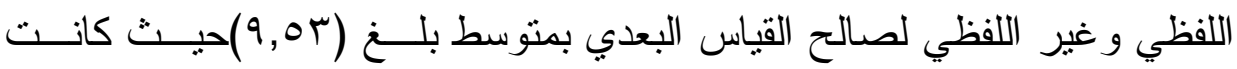


النتائج ( . . (t=-22.560, df=29, p=0)، و هذا يدل على تقدم المعلمات فـي مهارة الاتصال اللفظي و غير اللفظي بعد النطبيق. في ضوء النتائج التي تم التوصل اليها يمكن قبول الفرض الأول و الــــي

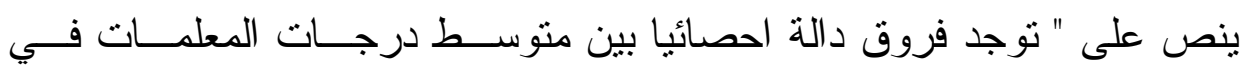

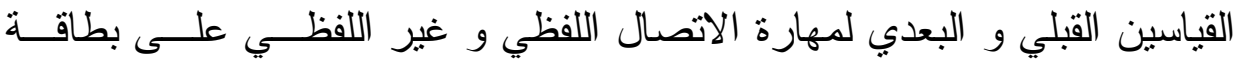
النقدير لصالح النطبيق البعدي." الفرض الثاني : توجد فروق دالة احسصائيا بـين متوســي درجـات المعلمات في القياسين القبلي و البعدي لـهارة التعزيز على بطاقة التقدير لصالح

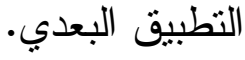

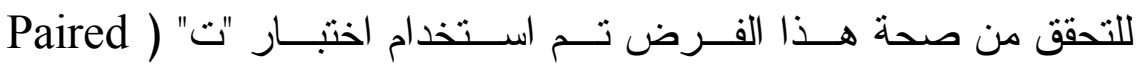
(Samples Test وذللك للتعرف على الفروق بين منوسطات درجات المعلىــات

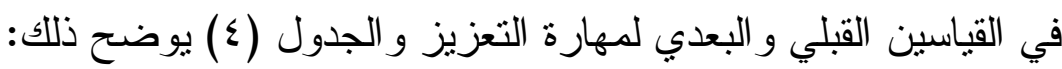

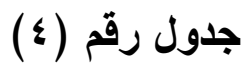

نتائج اختبار "T test لعينتين مترابطتين" لدلالة الفروق في القياس القبلي و البعدي للمعلمات لمهارة التعزيز.

\begin{tabular}{|c|c|c|c|c|c|c|c|}
\hline مستوى الدلالة & الحرية & $\begin{array}{c}\text { ق T T } \\
\text { ttes }\end{array}$ & الاحمر اف & المعياري & الحسابي & العدد & القياس \\
\hline \multirow{2}{*}{$\cdot, \cdots$} & \multirow{2}{*}{ rq } & \multirow{2}{*}{$\begin{array}{c}- \\
19, r V Y\end{array}$} & - ro9 & $1, \varepsilon \backslash \wedge$ & $r, r$. & r. & القياس القبلي \\
\hline & & & $\cdot, Y \wedge O$ & $1,07 r$ & $q, Y$. & r. & القياس البعدي \\
\hline
\end{tabular}




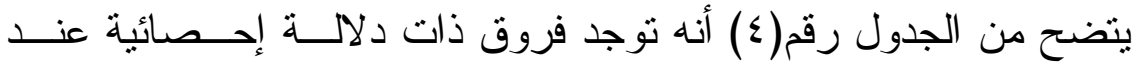

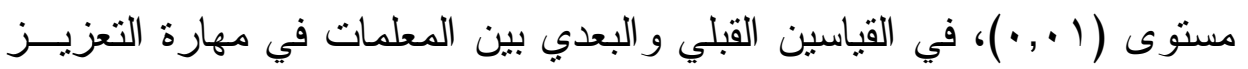

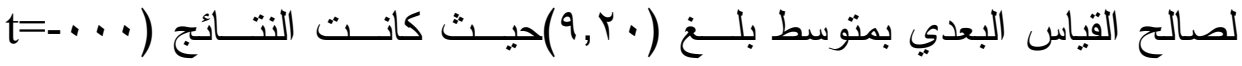
(19.372, df=29, p=0.

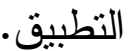

في ضوء النتائج التي تم التوصل اليها يمكن قبول الفرض الثاني والــــي

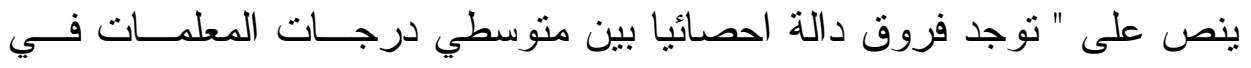

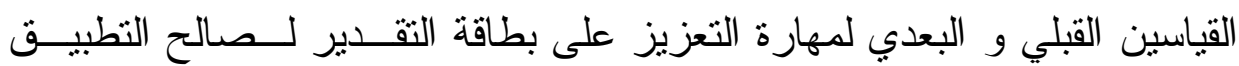

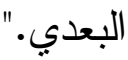

الفرض الثالث : توجد فروق دالة احــصائبا بـين متوســي درجـات المعلمات في القياسين القبلي و البعدي لمهارة الإدارة الصفية على بطاقة التقدير

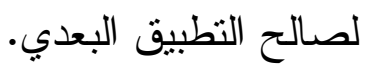

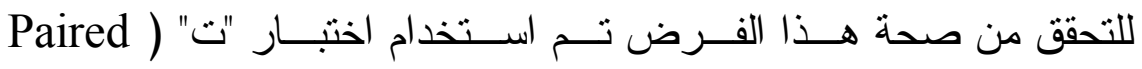

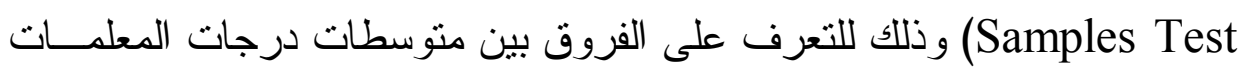

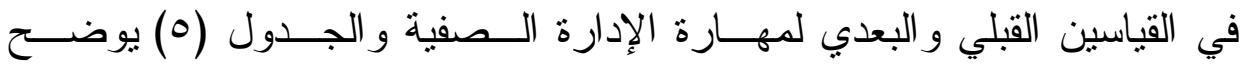
ذلك: 


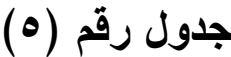

نتائج اختبار "T test لعينتين متر ابطتين" لدلالة الفروق في القياس القبلي و البعدي للمعلمات لمهارة الإدارة الصفية.

\begin{tabular}{|c|c|c|c|c|c|c|c|}
\hline مستوى الالالة & الحرجة & $\begin{array}{c}\text { ق T T } 1 \text { test } \\
\text { toمة }\end{array}$ & الاحمر اف & الالمعراري & الحسابي & العدد & القياس \\
\hline \multirow{2}{*}{,$\cdots$} & \multirow{2}{*}{ rq } & \multirow{2}{*}{$\begin{array}{c}- \\
r, r \cdot \lambda\end{array}$} & $\cdot, Y \backslash A$ & $1,19 \leq$ & r.ov & $r$. & القياس القبلي \\
\hline & & & $\cdot, r \leq \varepsilon$ & 1, & $q, v r$ & $r$. & القياس البعدي \\
\hline
\end{tabular}

يتضح من الجدول رقم(0) أنه توجد فروق ذات دلالــة إحــصائية عنــــ

مستوى ( ( , +)، في القياسين القبلي و البعدي بين المعلمات فـــي مهـارة الإدارة

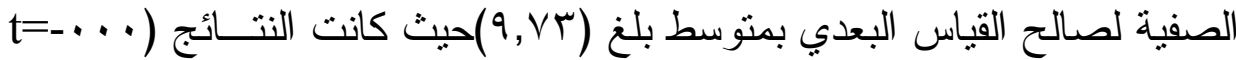
26.208, df=29, p=0.

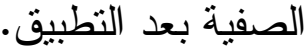
في ضوء النتائج التي تم التوصل اليها يمكن قبول الفرض الثالث و الــــي

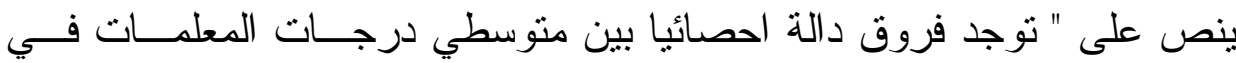

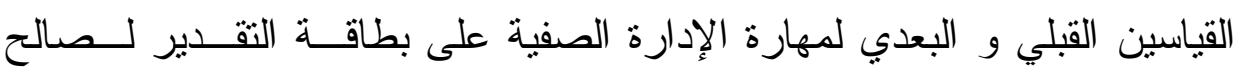

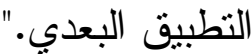

الفرض الرابع : توجد فروق دالة احــصائيا بـين متوســي درجـات المعلمات في القياسين القبلي و البعدي لمهارة القياس و الثقـــيم علــى بطاقـــة التقدير لصالح التطبيق البعدي. 
Paired Samples ) للتحقق من هذا الفرض تم اســتخدام اختبــار "ت Test وذللك للتعرف على الفروق بين متوسطات درجات المعلمات في القياسين القبلي و البعدي لمهارة القياس و التقويم و الجدول (؟) يوضح ذلك:

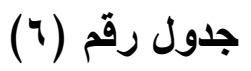

نتائج اختبار "T test لعينتين متر ابطتين" لالالة الفروق في القياس القبلي و البعدي للمعلمات لمهارة القياس و التقويم.

\begin{tabular}{|c|c|c|c|c|c|c|c|}
\hline الدلالة & الحرية & T- Tيمة Test & الالمحراف & المعياري & الحسابي & | العدد & القياس \\
\hline \multirow{2}{*}{0.000} & \multirow{2}{*}{29} & \multirow{2}{*}{$\begin{array}{c}- \\
29.328\end{array}$} & 0.152 & 0.834 & 2.83 & 30 & القياس القبلي \\
\hline & & & 0.217 & 1.189 & 9.97 & 30 & لقياس البعدي \\
\hline
\end{tabular}

ينضح من الجدول رقم (ا) أنه توجد فروق ذات دلالة إحـصائية عنــد

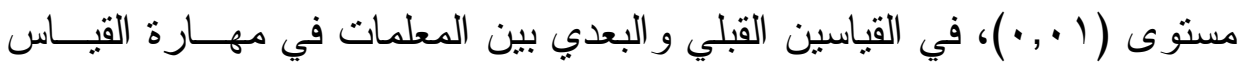

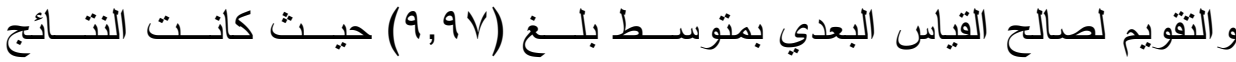
(t=-29.328, df=29, p=0....) و وهذا يدل على تقدم المعلمات في مهـارة القياس و النقويم بعد التطبيق. في ضوء النتائج التي تم التوصل اليها يمكن قبول الفرض الر ابع و الــــي ينص على " توجد فروق دالة احصائيا بين متوسطي درجــات المعلمــات فــي

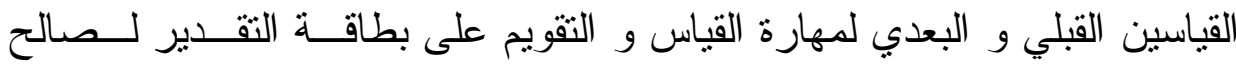

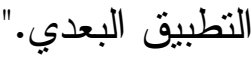


جدول رقم (V) يوضح قيمة ( ت ) للفروق بين المتوسطات

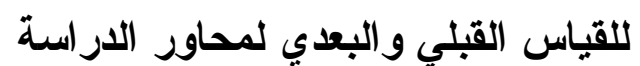

\begin{tabular}{|c|c|c|c|c|c|c|}
\hline \multirow{2}{*}{ مستوى الدلاكة } & \multirow{2}{*}{ قيمة ت } & \multicolumn{2}{|c|}{ القياس البعدي } & \multicolumn{2}{|c|}{ القياس القبلي } & \multirow{2}{*}{ المحور } \\
\hline & & $\varepsilon$ & م & $\varepsilon$ & r & \\
\hline$\cdot, \cdot 1$ & *YT,OT. - & $1, r O r$ & 9,0 r & $1, \leqslant 77$ & $r, v$. & مهارة اللفظي وغير \\
\hline$\cdot, \cdot 1$ & $19, r \vee Y-$ & $1,07 r$ & $9, Y$. & ।, §। & r, r. & مهارة التعزيز \\
\hline$\cdot, \cdot 1$ & $r \neg, r \cdot \Lambda-$ & עמז,ו & $9, \vee r$ & $1,19 \varepsilon$ & $r, O V$ & مهارة الإدارة \\
\hline$\cdot, \cdot 1$ & Ү৭, r Y^- & $1,1 \wedge 9$ & $9,9 \vee$ & •, & $r, \wedge r$ & مهارة القياس \\
\hline
\end{tabular}

*دال احصائيا عند مستوى ( 1 (., · )

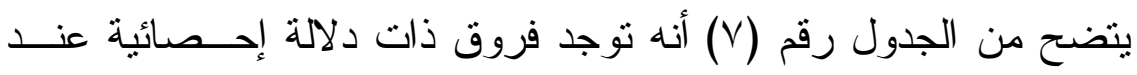

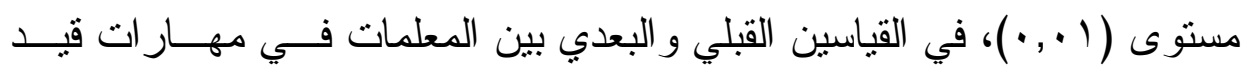

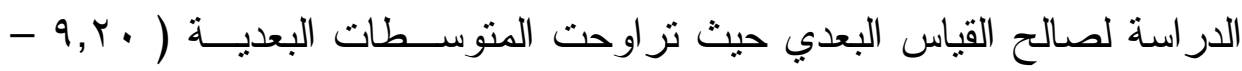

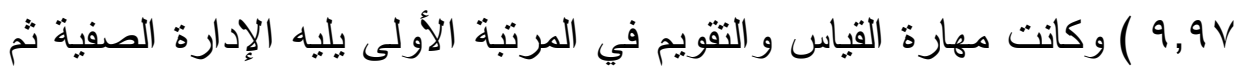
الاتصال اللفظي و غير اللفظي و أخير ا مهارة التعزيز. تحليل نتائج البحث: بطاقة التقدير

أظهرت نتائج التحليل المتعلقة باختبار دلالة الفرق بين متوسطى درجـات

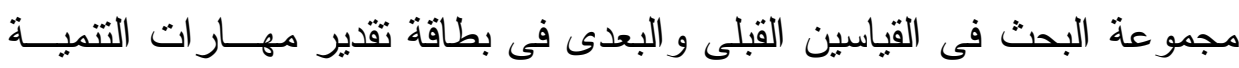

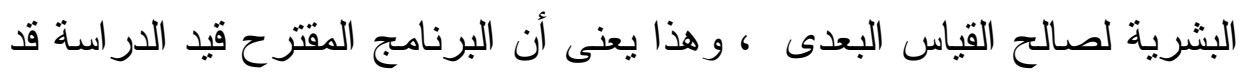


أثزر إيجابيًا فى تتمية مهار ات التتمية البشرية لدى معلمات الروضة، وقد يُعـزى البــ

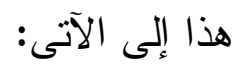

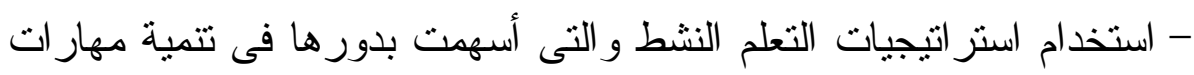

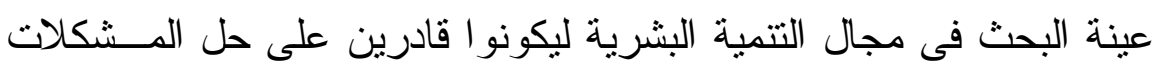

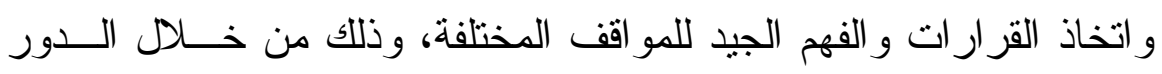

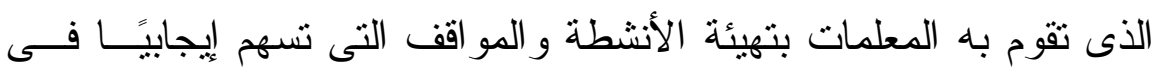

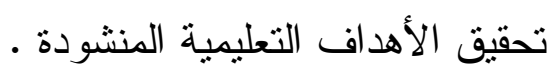

- طبيعة التعلم النشط حيث إنه يستخدم استر اتيجيات ووسائل تعليميــة شــائقة تثزي المعلمات وتنزي معار فها ومهار اتها.

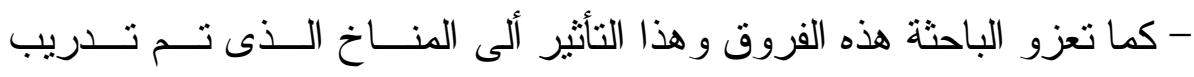

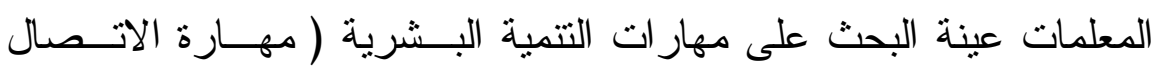

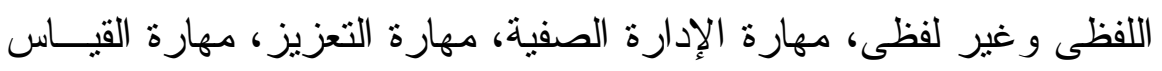

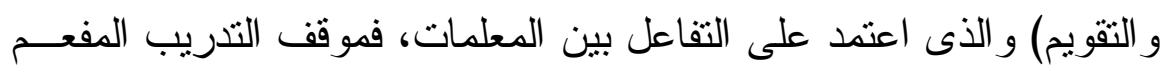

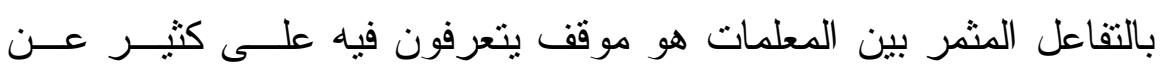
أنفسهم، وكذلك عما يستطيعون تقديمه فى البيئة المحيطة.

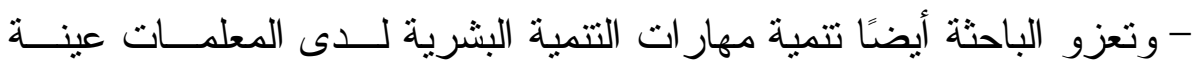

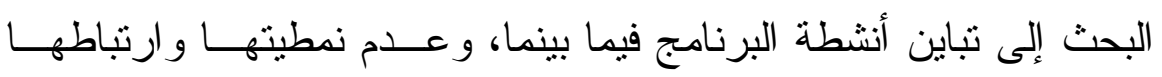

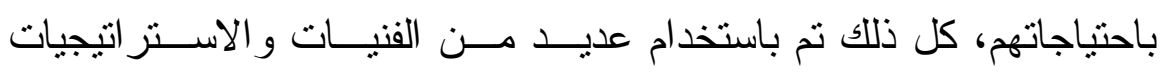

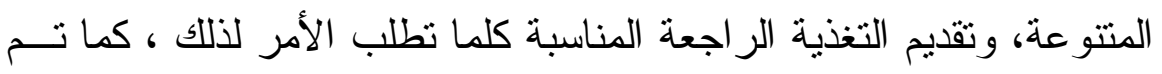
تقديم الأنشطة بعد تهيئة المعلمات لذلك. 
- اتسمت الجلسات و التعاملات مع المعلمات بالمرونة، و القدرة على تكـــين علاقات فعالة، مما أعطى للبرنامج معنى أكبر و أهداف أوسع. - أنشطة البرنامج كانت فعالة وموز عة على اللقاءات، سو اء كانت فرديــة أو

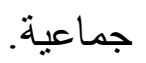
- فتح التدريب آفاقًا للمعلمين للاطلاع و المناقشة. وقد اتفقت هذه النتائج مع ما توصلت إليه نتائج در سات وبحوث كل مــن

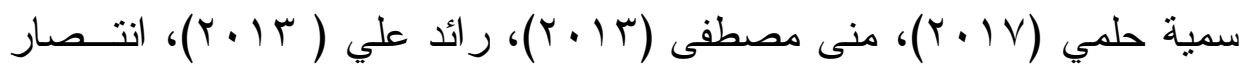

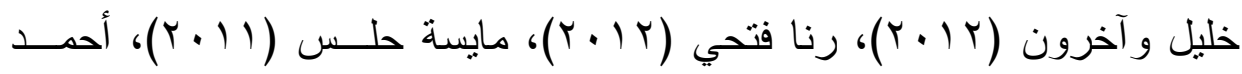

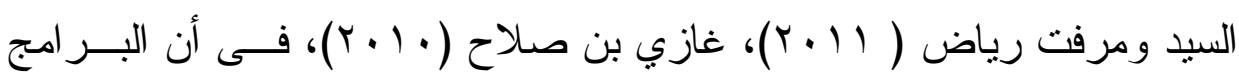

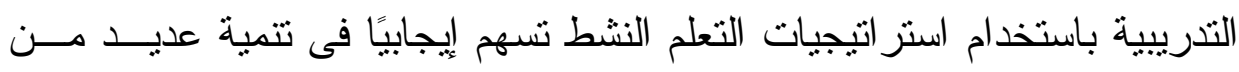

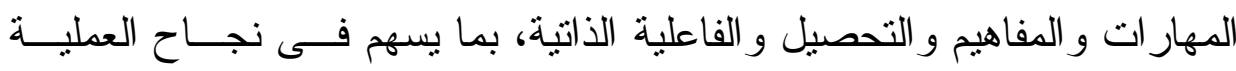

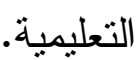

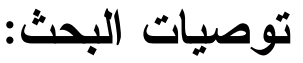

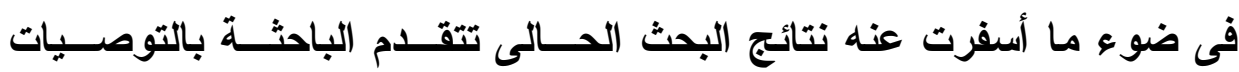

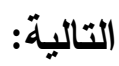

1-توفير بيئة تعليمية تقافية تخدم احتياجات المعلمات العلمية و الثقافيــة مــع تتمية مهار اتهم وقدر اتهم الذاتية وربطهم بما يدور في بيئتهم.

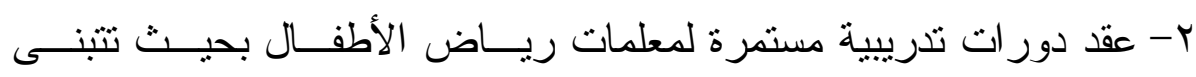
اتجاهات حديثة فى التدريب.

المجلد الخامس




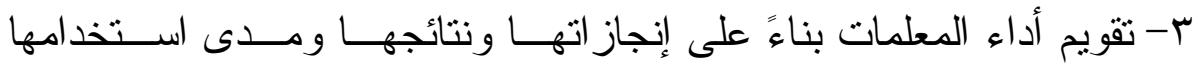

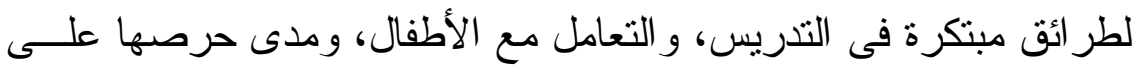
الارتقاء بالبيئة المدرسية.

ع - تطوير بر امج كليات التربية لإعداد المعلمات القـادرات علـى مـسايرة

$$
\text { المتغير ات المحلية و الإقليمية و العالمية. }
$$

0- تضمين بر امج التتمية البشرية ضمن بر امج إعــاد وتــدريب المعلدــات لتكون قادرة على اكتساب المهار ات المختلفة.

1- العمل على توفير ميز انية مناسبة للأنشطة التزبوية و الأجهـزة و الأدوات

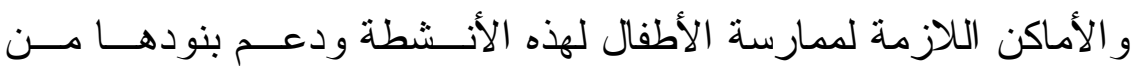

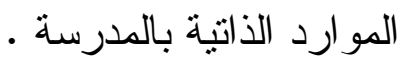

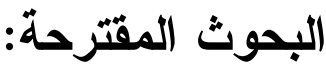

1- فاعلية برنامج حاسوبى قائم على التتمية البشرية فــى تتميــة مهــار ات تصميم المقررات الكترونية الو اجب تو افرها لاى المعلمات بكلية تربية.

r- فاعلية أسلوب التعزيز فى نتمية المهــارات الاجتماعيــة لــدى أطفــال

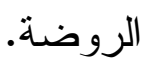

r- فاعلية برنامج الكترونى قائم على استر اتيجيات التعلم النشط فى تطــــير

الكفايات التعليمية اللازمة لدى المعلمات فى المر احل التعليمية المختلفة.

ع - فاعلية استر اتيجية التعلم القائم على حل المشكلات فى علاج الاضطر ابات

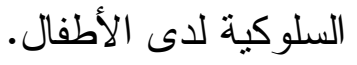




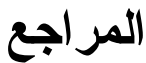

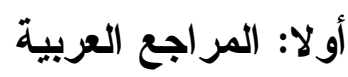

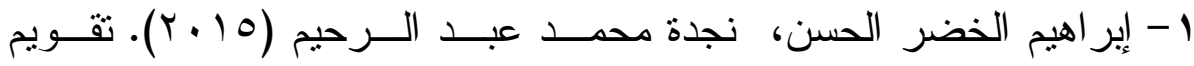

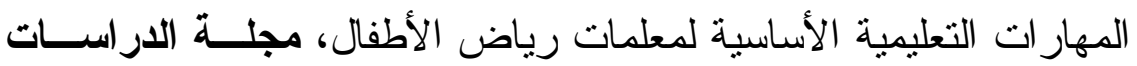

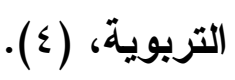

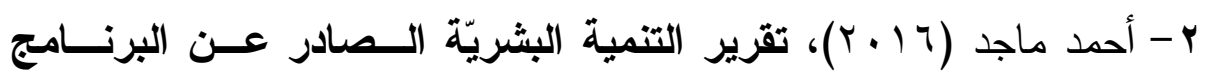

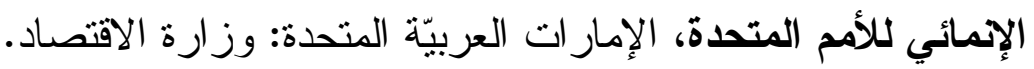
r- از هار سلمان هادي (11 + ب). التعليم مؤشر ا من مؤشر ات التتمية درارسة و اقع المستوى التعليمي في مصر، مجلة ديالي، (ror).

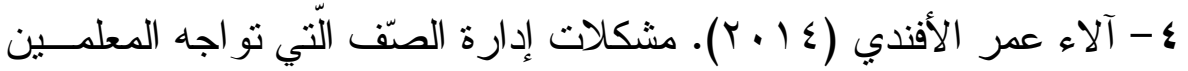

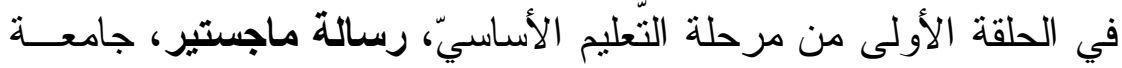
حلب.

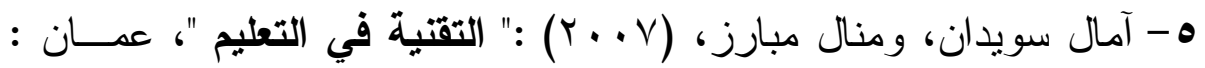

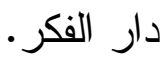

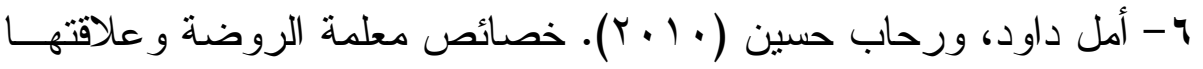

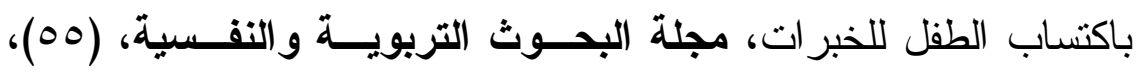

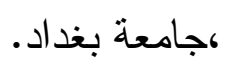

V أمل سعيد القعطاني (ع ( • Y). فاعلية برنامج مقترح قائم علـى الــتعلم النشط و واستر اتيجيات فى تعديل الاعتقادات نحوه لدى معلمات الجغر افيــا

المجلد الخامس


للصف السادس الابتدائى بالرياض، مجلة العلــوم التربويــة و النفـــية،

$$
\text { . } 20 \Lambda-\varepsilon \mid \vee ،(1) 10
$$

1- انتصار خليل عشا، فريال محمد أبو عو اد، إلهام علـي الــشلبي، إيمسـان

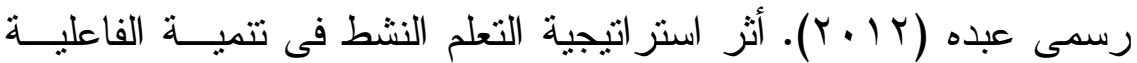

الذاتية و التحصيل الأكاديمى لدى طلبة كلية العلوم التربوية التابعة لوكالـــة

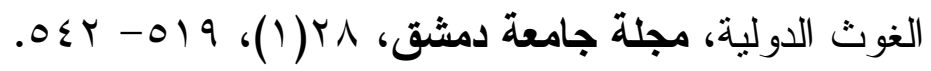

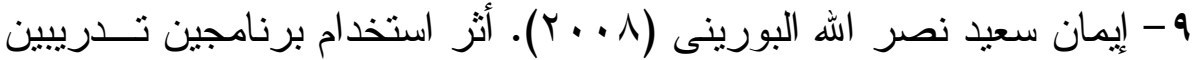

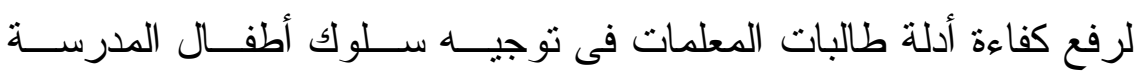
الابتدائية وحل مشكلاتهم، رسالة دكتور اه، جامعة القاهرة.

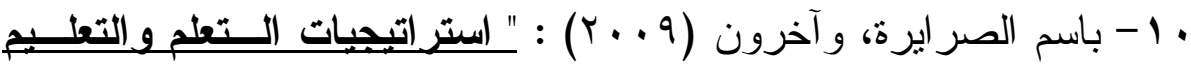
النظرية و التطيقيق"، اربد: عالم الكتاب الحديث.

11 - باسم صبرى محمد سلام، (1 ( • ץ). أثر استر اتيجية المساجلة الحلقيــة في تدريس الدراسات الاجتماعية على تتمية بعض مهار ات التفكير الجانبي

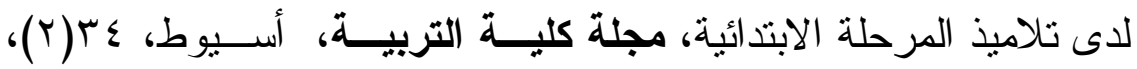
$\varepsilon \wedge 9-\varepsilon \leqslant$.

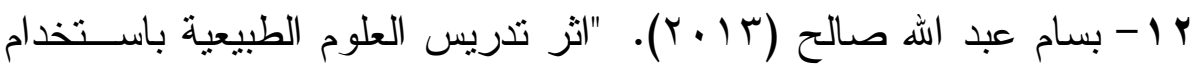

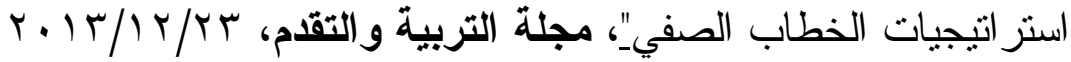

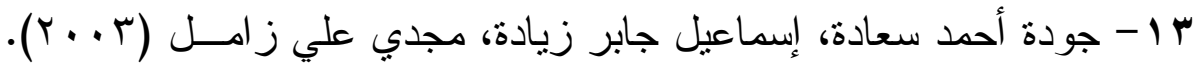
أثر تدريب المعلمات الفلسطينيات على أسلوب النعلم النشط فى التحــصيل 
الآتى و المؤجل لديهن فى ضوء عدد مــن المتغيـر ات، مجلــة العلــوم

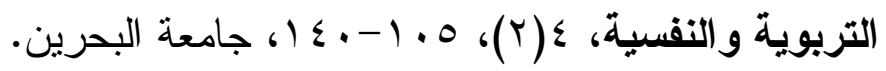

ـ ا - جودت أحمد سعادة ، و آخرون ( ؟ . . ץ). التعلم النشط بين النظريـــة والتطبيق، عمان، الأردن :دار الثروق

ه - جيهان محمود محمد جودة (0 . . ب). فعالية برنامج تــدريبى لإكــساب

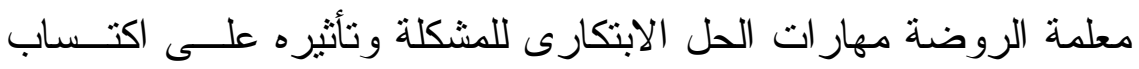
الطفل لتلك المهار ات، رسالة دكتور اه، جامعة القاهرة.

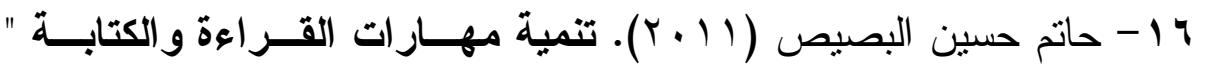
استر اتيجيات متعددة للتدريس والتقويم"، دمشق: الهيئة العامة الـسورية للكتاب.

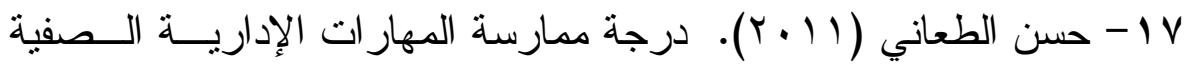

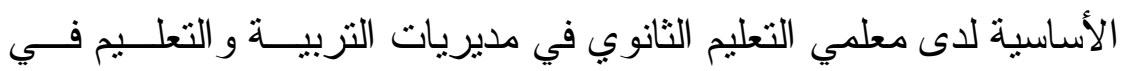

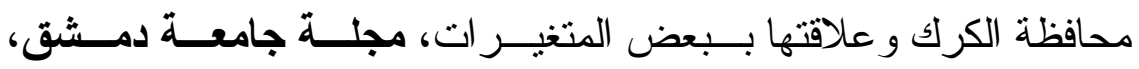

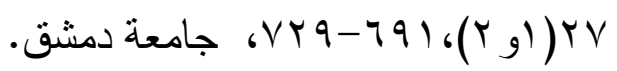

1 1 - حسن يحيى، فوزي الثربيني، أسماء الأهدل، أيمــان بار عيــدة، داليــا

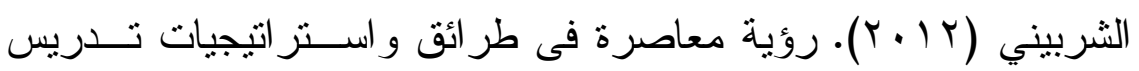
المو اد الاجتماعية، مجلة الخوارزم العلمية، الرياض. 9 1 - خالد الحربي ( • ( †). أثز التعلم النشط في التحصيل و الاتجاه نحو مادة الفيزياء لدى طلاب الصف الثاني الثـانوي بالمدينـــة المنــورة، رســـالة ماجستير، المدينة المنورة:جامعة طيبة. 


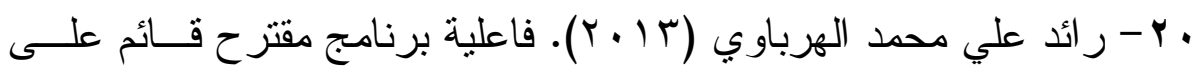

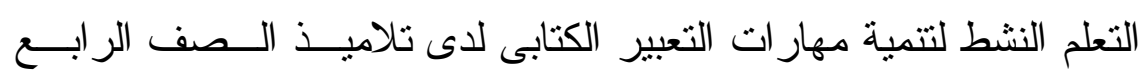
الأساسى بمحافظة عزة، رسالة ماجستير، جامعة الأزهر

ا Y- رضا سلامة محمد المو اضية (11 + (Y). التنمية المهنية لمربيات رياض

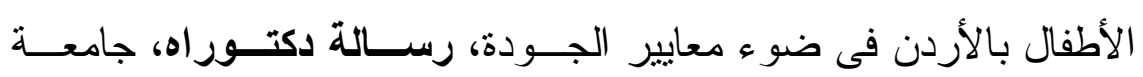
القاهرة. r Y - رضا عبد الجبار سلمان الثمري، حسـون عبــود دبعــون الجبـوري

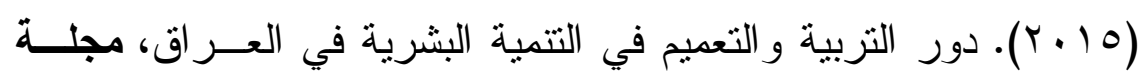

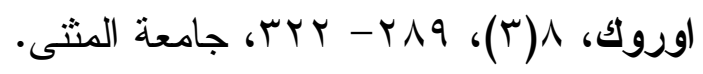

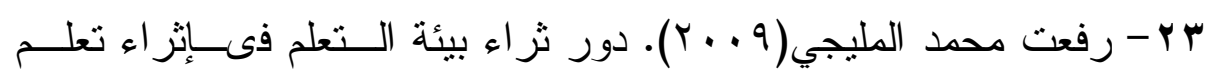

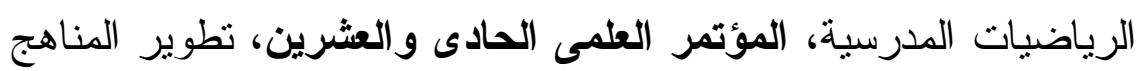

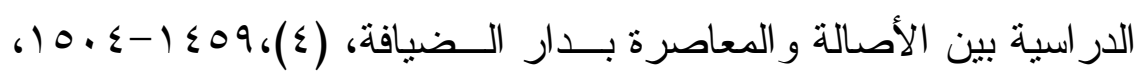
جامعة عين شمس.

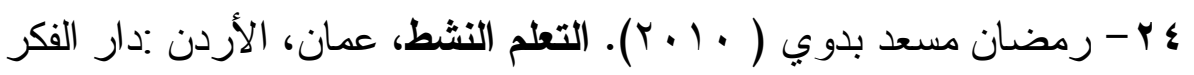

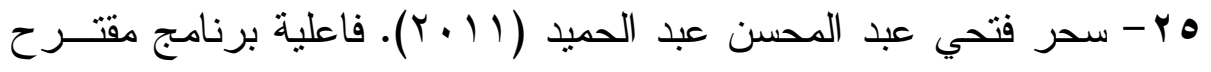

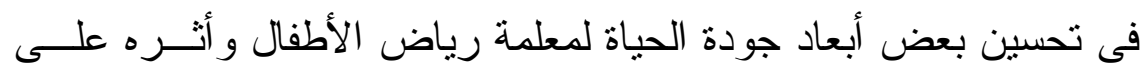
الكفايات المهنية لديها، رسالة دكتور اه، جامعة القاهرة.

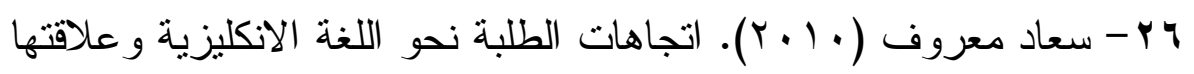

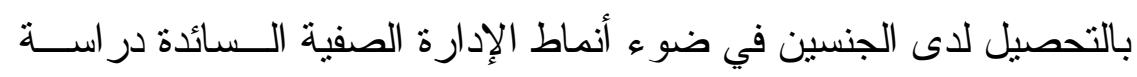

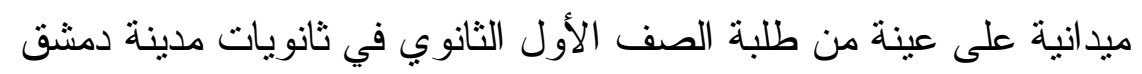




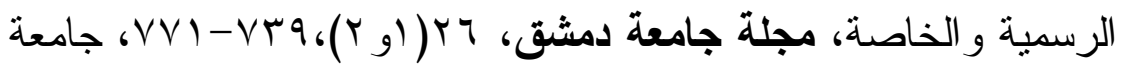
دمشق.

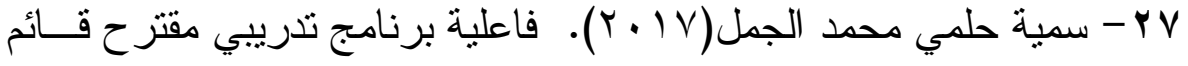

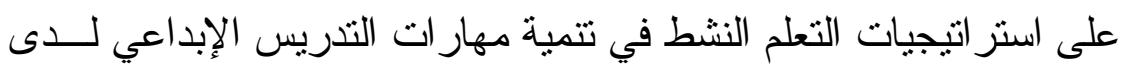

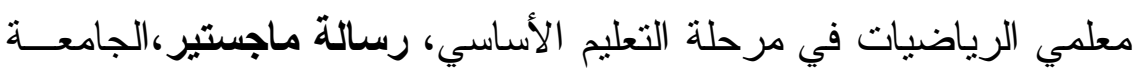

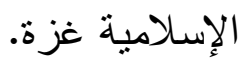

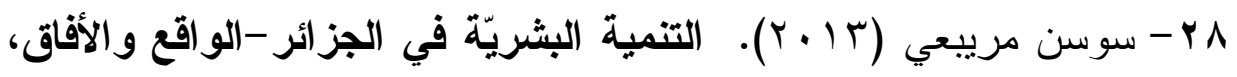
الجز ائر : جامعة منتوري.

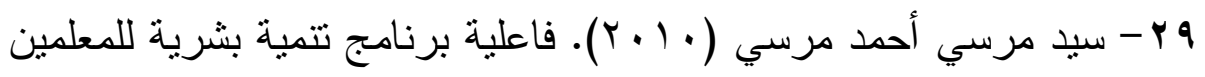

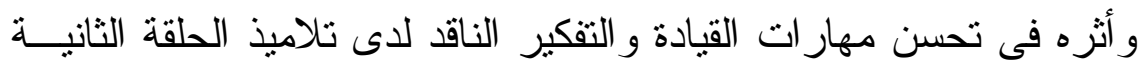
من التعليم الأساسى، رسالة ماجستير، جهامعة القاهرة.

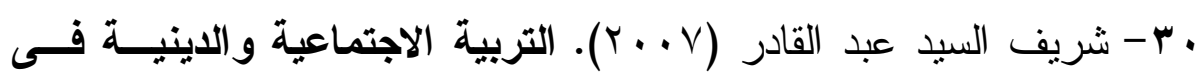
رياض الأطفال ،آلية رياض الأطفال، جامعة القاهرة.

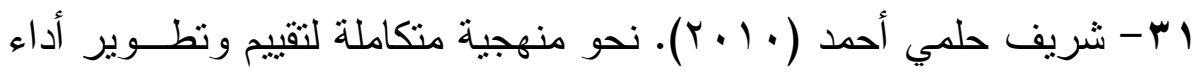

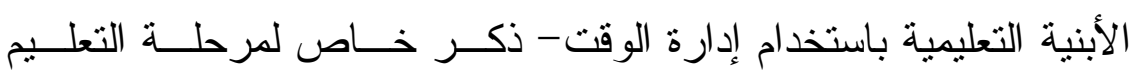
الأساسى، رسالة دكتور اه، جامعة القاهرة.

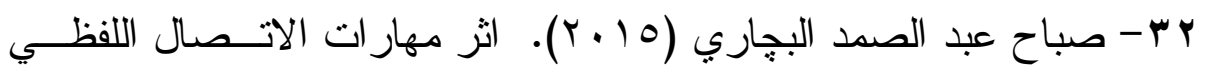

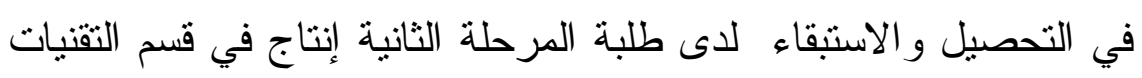

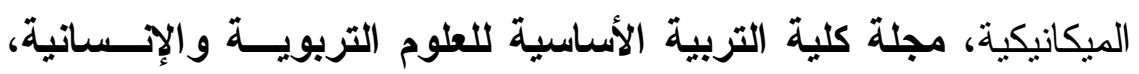

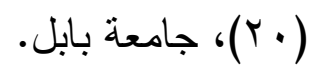




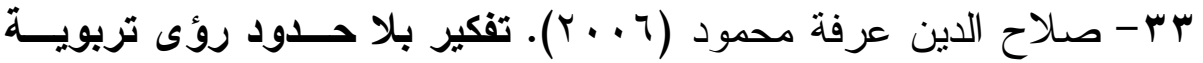
معاصــرة فـي تعلـيم التفكير وتعلمه، القاهرة :عالم الكتب.

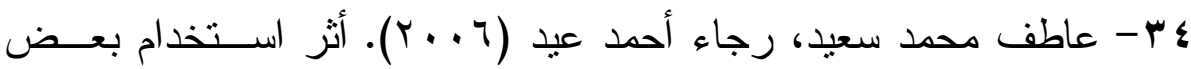

استر اتيجيات التعلم النشط فى تدريس الدر اسات الاجتماعية على التحصيل وتتمية مهار ات حل المشكلات لدى تلاميذ المرحلـــة الإعداديــة، مجلـــة الار اسات فى المناهج وطرق التدريس، (1) (1).

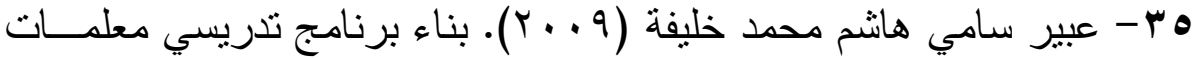
رياض الأطفال فى ضوء الكفايات المطلوبة، رسالة ماجسـتير، جامعــة

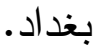

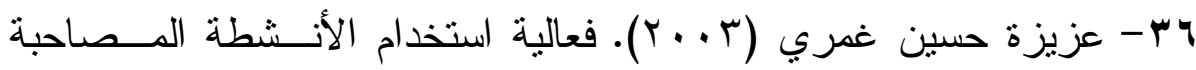
التعليمية لاكتساب المفاهيم الجغر افية لدى تلميذات الصف الر ابع الابتدائى بمحافظة جدة، رسالة ماجستير، جامعة الملك عبد العزيز .

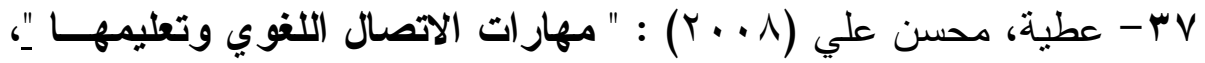

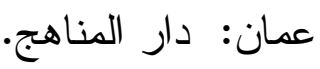

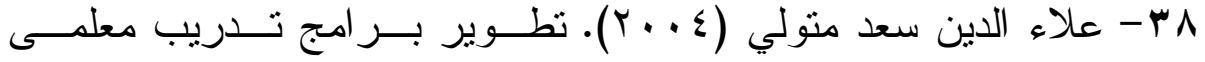
الرياضيات بسلطنة عمان فى ضوء الاتجاهــات العالميــة المعاصــرة، المؤتمر العلمى السادس عشر، الجمعيــة المــصرية للمنــاهج وطــرق التدريس، (، جامعة عين شمس.

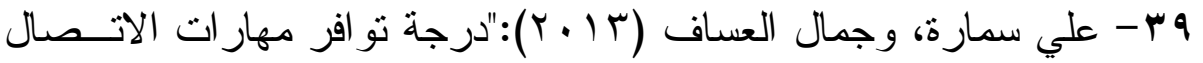
الفعال لدى معلمي اللغة العربية في مدارس وكالة الغوث في الأردن مــن 


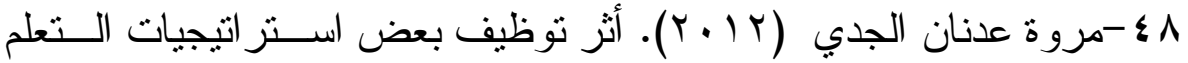

النشط في تدريس العلوم على تتمية المهار ات الحياتية لدى طلبة الــصف

الر ابع في محافظة غزة، رسالة ماجستير ، جامعة الأزهر ، كلية التزبية.

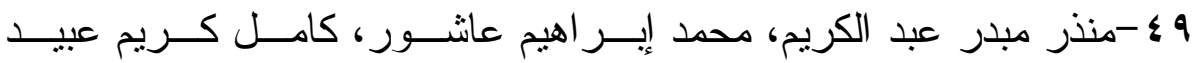

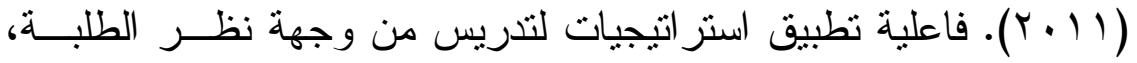

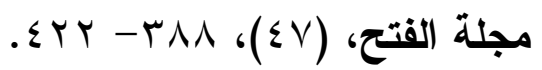

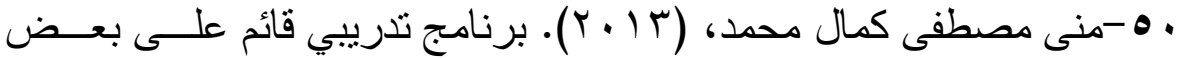

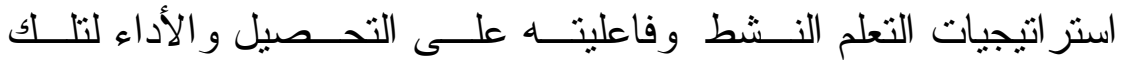
الاستر اتيجيات و التفكير الناقد لمعلمي العلوم حديثي التخرج، مجلة التربية

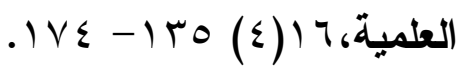

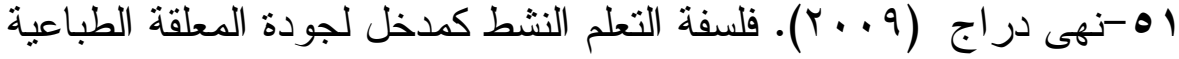
لطلاب كلية التربية النوعية، المؤتمر السنوي الــدولي الأول العربـي، الر ابع ( الاعتماد الأكاديمي لمؤسسات وبر امج التعليم العالي النوعي فـي

$$
\text { مصر و العالم العربي الو اقع و المأمول. }
$$

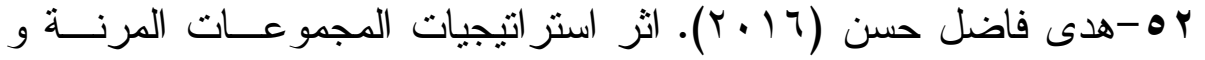
المقابلة الثالثية الخطوات فى تحصيل مادة تاريخ الحضار ات القديمة لدى طالبات الصف الأول المتوسط، مجلة البحوث التربوية والنفسية، (10)،

$$
. r \leqslant 1-r r t
$$

به-هدى محمود الناثف ( • + ب). معلمــة الروضــة، طب، الأردن : دار

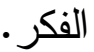




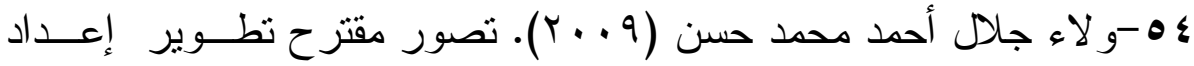

معلمات رياض الأطفال بكلية التزبية النوعية بالفيوم فى ضـــوء خبــر ات ات بعض الدول الأجنيية، رسالة ماجستير، جامعة القاهرة.

ه هـيعقوب أبو حلو، نوفيق درعي، صالح الطيطي، سليمان نجم، عيسى أبو

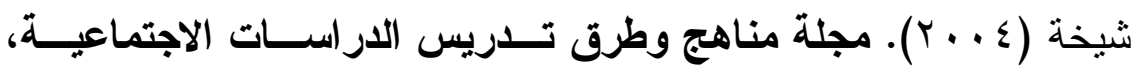
جامعة القدس. ثانيًا: المر اجع الأجنبة

1- Babayi K. et al (2013). The study Efficacy of time management training on increase academic time management of student, Elsevier Journal,84, 134-138.

2- Haji Z. et al, (2011). Communication skills among university student, EL Sevier Journal, 59, 71-76.

3- Kaleigh, Q (2013). Cooperative Strategies. Paper presented at ALT conference. Retrieved April 7, 2017, from:

http://education.uwinnipeg.ca/pdf_files/Handout $\% 20$

$\% 20$ Cooperative $\% 20$ Learning $\% 20$ Strategies.pdf

4- Menon, Maria, 2012, Do Beginning Teachers receive adequet support from their headteachers. 2111/8/ تــ 31

http:/ema.sagepub.com/content/40/2/217.abstract 